\title{
Pd-Catalyzed Intermolecular Dehydrogenative Heck Reactions of Five-Membered Heteroarenes
}

\author{
Jean Le Bras and Jacques Muzart* \\ Institut de Chimie Moléculaire de Reims, UMR 7312 CNRS-Université de Reims Champagne-Ardenne, \\ BP 1039, CEDEX 2, 51687 Reims, France; jean.lebras@univ-reims.fr \\ * Correspondence: jacques.muzart@univ-reims.fr
}

Received: 21 April 2020; Accepted: 14 May 2020; Published: 19 May 2020

\begin{abstract}
The Pd-mediated cross-coupling of (hetero)arenes with alkenes may be an effective method for the formation of a C-C bond from two $\mathrm{C}-\mathrm{H}$ bonds. Discovered by Fujiwara and co-workers in 1967 , this reaction led to a number of reports that we firstly highlighted in 2011 (review with references till June 2010) and for which, we retained the name "dehydrogenative Heck reaction". The topic, especially the reactions of five-membered heteroarenes, has been the subject of intensive research over the last ten years. The present review is limited to these dehydrogenative Heck reactions published since 2010, underlining the progress of the procedures.
\end{abstract}

Keywords: palladium; heteroarenes; dehydrogenative cross-couplings; $\mathrm{C}-\mathrm{H}$ activation

\section{Introduction}

Palladium-catalyzed C-H functionalization has been at the forefront of organic synthesis over the last half-century [1-4]. Through the multitude of reactions, the coupling leading to a $\mathrm{C}-\mathrm{C}$ bond from two $\mathrm{C}-\mathrm{H}$ bonds is an atom-economical process because any prefunctionalization is required. In the late sixties, Fujiwara's team disclosed the $\mathrm{Pd}^{\mathrm{II}}$-mediated synthesis of stilbene from the cross-coupling of styrene with benzene [5,6]. This synthesis contrasts with the usual Pd-catalyzed method independently discovered by the teams of Mizoroki [7], Julia [8], and Heck [9] (The Mizoroki publication, submitted on 20, October, 1970, was cited by Heck's team which submitted their report on 13, January, 1972. On 12, January, 1971, Julia's team deposited a "Pli cacheté", i.e., a sealed envelope, to the Société Chimique de France, which was open on 5, May, 1973.), which requires phenyl halide instead of benzene. Although the above Fujiwara cross-coupling initially occurred with a very low palladium turnover [6], such dehydrogenation reactions, which could be named "Dehydrogenative Heck Reactions" (DHRs), have been the subject of intensive research over the last half century leading to efficient catalytic procedures. We previously reviewed the corresponding literature with references until sep 2010 [10]. Through the DHRs, those of the five-membered heteroarenes have especially retained our attention, and are the subject of the present review which is limited to reports of the last ten years (For more general reviews containing some examples, see [11-15].) The reactions of fused bicyclic heteroarenes that do not involve the $\mathrm{C}-\mathrm{H}$ bond of the small hetero ring (See examples in [16-18]) will be discarded. For convenience, the framework of the text depends on the nature of the aromatic substrate.

The simplified mechanism of DHRs usually admitted implicates the activation of a C-H bond of the arene by $\mathrm{Pd}^{\mathrm{II}}$ species leading to an arylpalladium intermediate which adds to the alkene to provide $\mathbf{1 A}$ or $\mathbf{1} \mathbf{A}^{\prime}$ (Scheme 1 , arene activation). Subsequent $\beta$-H elimination delivers the cross-coupling product and $\mathrm{Pd}^{0}$. The active $\mathrm{Pd}^{\mathrm{II}}$ species are regenerated with an oxidant. Another mechanism involving the coordination of the alkene to afford a $\eta^{2}$-palladium complex susceptible to nucleophilic attack by the arene has been hypothesized (Scheme 1 alkene activation) [19]. Such a reaction would also afford intermediate $\mathbf{1} \mathbf{A}$ or $\mathbf{1} \mathbf{A}^{\prime}$. Both catalytic cycles describe dehydrogenative cross-coupling reactions, but a 
reaction via the alkene complex cannot be named DHR. Broggini's team proposed the term "alkene activation" for the corresponding catalytic cycle [19]. In fact, coordination of the alkene to palladium decreased the electron density of the double bond, leading to its activation towards nucleophilic attack, that is, a Friedel-Crafts reaction. Electrospray ionization mass spectrometry (ESI-MS) [20-26] and nuclear magnetic resosnance (NMR) [27] studies would favor the arene activation process for the majority of the dehydrogenative cross-coupling reactions.

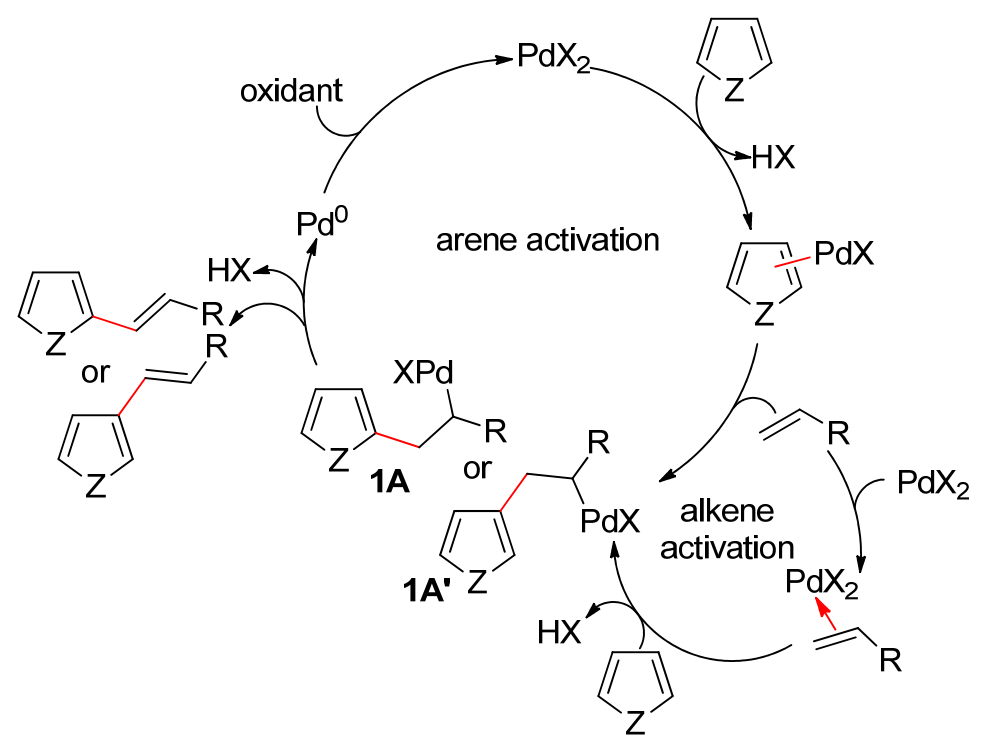

Scheme 1. Catalytic cycles of the dehydrogenative cross-coupling reactions.

The site selectivity of the heteroarene is governed by the "innate" or "guided" C-H bond activation [13]. The former relies on the electronic properties of the heterocycle induced by the heteroatom [28], whereas the latter is relevant to either a directing group or a specific additive.

\section{S-Arenes}

\subsection{Thiophenes}

Subsequently to the report by Fujiwara's team on the cross-coupling of thiophene with styrene mediated by stoichiometric amounts of $\mathrm{Pd}(\mathrm{OAc})_{2}$ in refluxing $\mathrm{AcOH} / \mathrm{dioxane}$ [29], Kozhevnikov disclosed catalytic conditions with $\mathrm{Cu}(\mathrm{OAc})_{2}$ to regenerate active $\mathrm{Pd}$ species and $\mathrm{CaCl}_{2}$ as additive in $\mathrm{DMF}$ [30]. The catalyst turnover was low and other reoxidation methods, namely, $\mathrm{Cu}(\mathrm{OAc})_{2} / \mathrm{air}[31,32]$, $\mathrm{H}_{6} \mathrm{PMo}_{9} \mathrm{~V}_{3} \mathrm{O}_{40}$ [33], $\mathrm{HPMo}_{11} \mathrm{~V} / \mathrm{air}$ [34], and AgOAc [35], have been then proposed with various additives and solvents [10]. A number of procedures have been published since 2010.

Liu's team carried out the cross-coupling with allyl esters using $\operatorname{Pd}(\mathrm{OAc})_{2} / \mathrm{Ag}_{2} \mathrm{CO}_{3}$ in DMSO/dioxane leading to a 88:12-99:1 mixture of linear and branched compounds via $\beta$-H elimination rather than $\beta-\mathrm{OCOR}^{2}$ elimination (For such competitions, see [36]) (Equation (1)) [37]. Other oxidants and use of pure solvents greatly depreciated the yields. The reaction also occurred with allyl phenyl 
ether and 1-octene (Equation (2)). The formation of linear/branched products from 1-octene will be discussed in Sub-chapter 6.3.

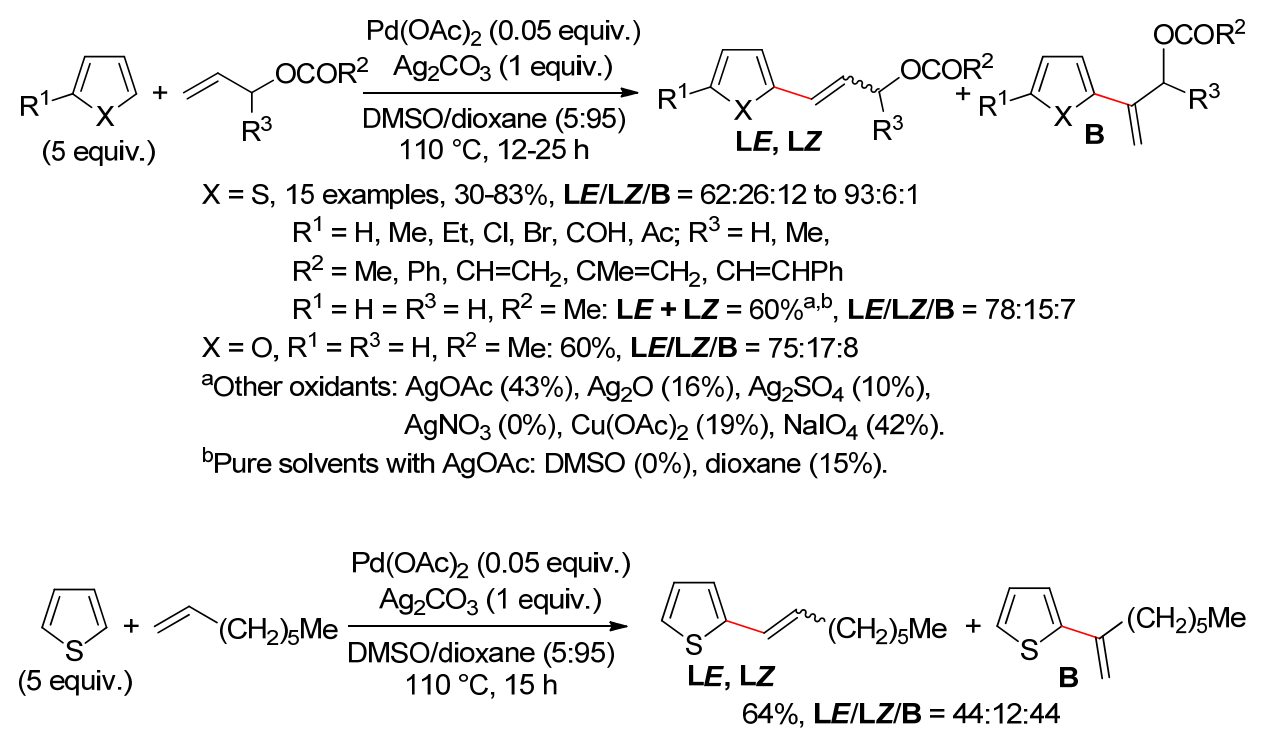

In DMSO/AcOH, thiophenes underwent efficient $\mathrm{Pd}(\mathrm{OAc})_{2}$-catalyzed aerobic DHRs with styrenes (Equation (3)) [22]. Under these conditions, we observed that addition of metallic co-oxidants, such as $\mathrm{AgOAc}, \mathrm{Cu}(\mathrm{OAc})_{2}, \mathrm{Mn}(\mathrm{OAc})_{\mathrm{n}}(n=2$ or 3$)$, or $\mathrm{MnO}_{2}$, disfavored the yields. (For the power of $\mathrm{DMSO} / \mathrm{O}_{2}$ to regenerate active $\mathrm{Pd}^{\mathrm{II}}$ species, see $[38,39]$.)

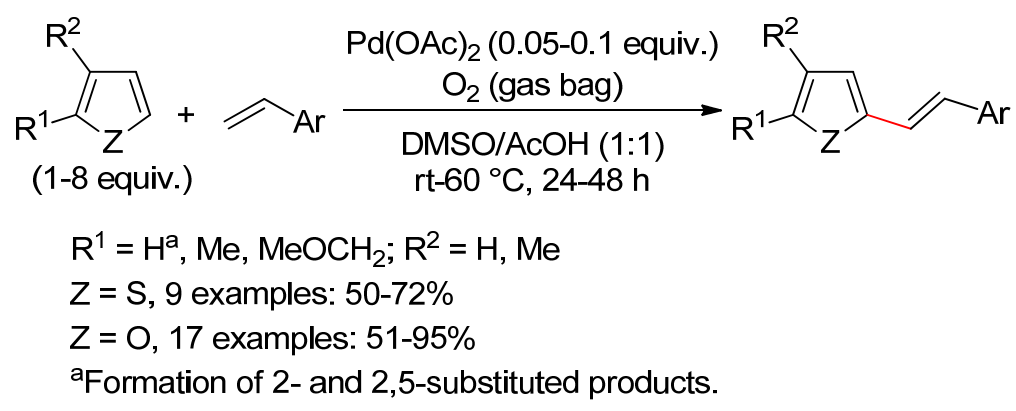

$\mathrm{Xu}$ and co-workers reported the $\mathrm{Pd}(\mathrm{OAc})_{2}$-catalyzed $\mathrm{C} 2$-substitution of thiophenes with allylamines using $\mathrm{Ag}_{2} \mathrm{CO}_{3} / \mathrm{Cu}(\mathrm{OAc})_{2} /$ air as reoxidant (Equation (4)) [40]. Yields diminished with other Pd catalysts. The method led to C3-substition from 2,5-dimethylthiophene (Equation (5)).

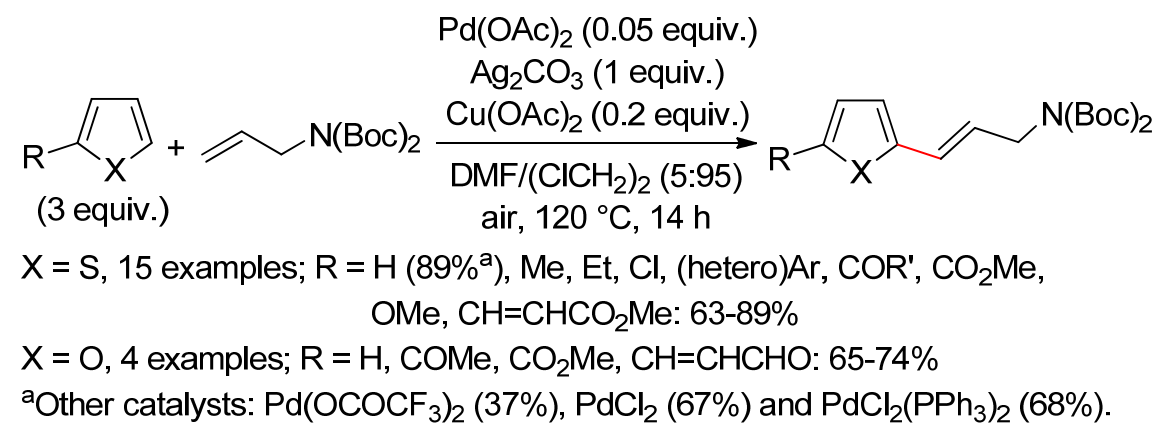




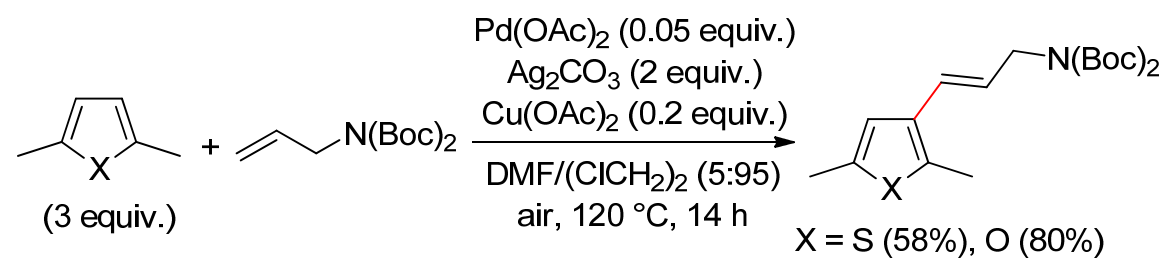

The aerobic DHR with allylic alcohols disclosed by Jiang's team (In contrast to the captions of the publication tables [41], oxygen was the sole oxidant. Personal communication from $\mathrm{H}$. Jiang, 24, April, 2020.), led to aldehydes or ketones (Equation (6)) through hydrogen migration [41] as that occurs from the Heck reaction of such substrates [42].

$$
\begin{aligned}
& \text { X=S, } \mathrm{R}^{2}=\mathrm{H}, \mathrm{R}^{1}=\mathrm{Cl}(87 \%), \mathrm{CH}=\mathrm{CHCO}_{2} \mathrm{Me}(68 \%) \\
& X=\mathrm{AcOH}, 50^{\circ} \mathrm{C}=\mathrm{Me}, \mathrm{R}^{1}=\mathrm{Cl}(45 \%) \\
& X=O, \mathrm{R}^{2}=\mathrm{R}^{1}=\mathrm{Me}(66 \%)
\end{aligned}
$$

Procedures using palladium associated to various ligands have been reported for olefination with acrylates, enones, acrylamides, styrenes, vinyl phosphonates, or sulfones (Equations (7) and (8) [24], Equations (9) and (10) [43], Equations (11) and (12) [44], Equation (13) [45], and Equation (14), respectively [46]).
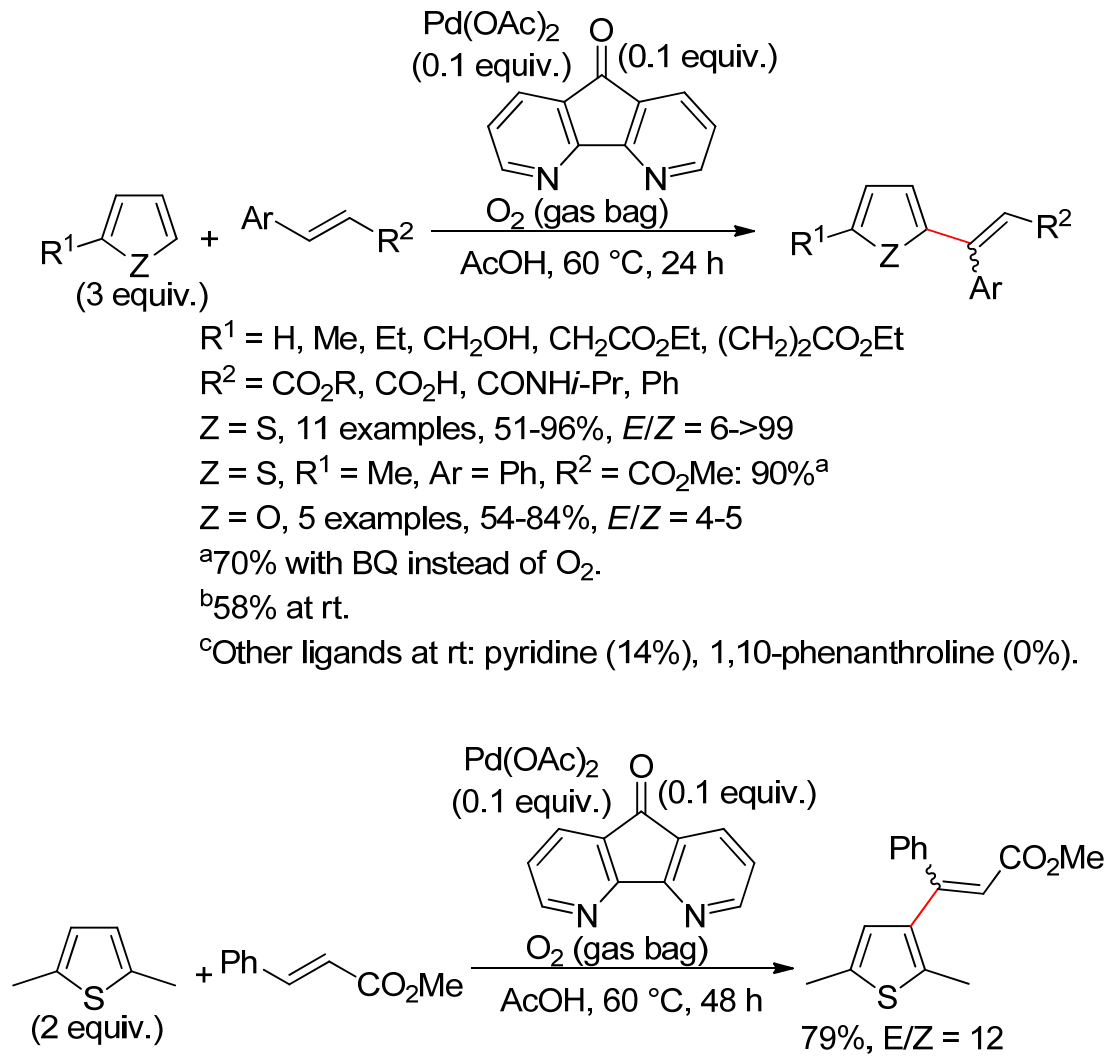


$$
\begin{aligned}
& \mathrm{Pd}(\mathrm{OAc})_{2} \text { (0.05 equiv.) } \\
& i-\operatorname{Pr}{ }^{\mathrm{CO}_{2} \mathrm{H}} \\
& \text { SPh (0.05 equiv.) }
\end{aligned}
$$

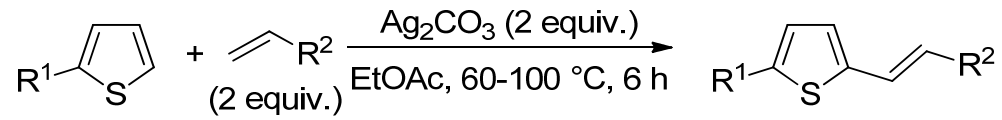

16 examples 40-97\%; $\mathrm{R}^{1}=\mathrm{H}, \mathrm{Me}$, OMe, $\mathrm{Ph}, \mathrm{Br}, \mathrm{Cl}, \mathrm{CO}_{2} \mathrm{Me}, \mathrm{CN}$ $\mathrm{R}^{2}=\mathrm{CO}_{2} \mathrm{R}, \mathrm{COMe}, \mathrm{CONMe}_{2}, \mathrm{PO}(\mathrm{OMe})_{2}, \mathrm{SO}_{2} \mathrm{Ph}$ $\mathrm{R}^{1}=\mathrm{H}, \mathrm{R}^{2}=\mathrm{CO}_{2} \mathrm{Bu}: 48 \%$ plus $13 \%$ of the diolefinated product.

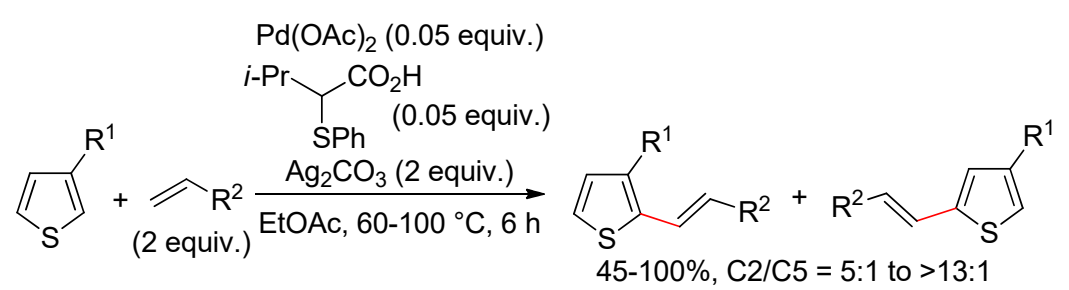

14 examples; $\mathrm{R}^{1}=\mathrm{Me}, \mathrm{Et}, \mathrm{Ar}, \mathrm{Cl}, \mathrm{CO}_{2} \mathrm{Me} ; \mathrm{R}^{2}=\mathrm{CO}_{2} \mathrm{R}, \mathrm{COMe}, \mathrm{CONMe}_{2}, \mathrm{PO}(\mathrm{OMe})_{2}, \mathrm{SO}_{2} \mathrm{Ph}$ $R^{1}=\mathrm{Me}, \mathrm{R}^{2}=\mathrm{CO}_{2} \mathrm{Bu}: 69 \%, \mathrm{C} 2 / \mathrm{C} 5=9: 1^{\mathrm{a}}$

$\mathrm{R}^{1}=\mathrm{CO}_{2} \mathrm{Me}, \mathrm{R}^{2}=\mathrm{CO}_{2} \mathrm{Bu}: 41 \%, \mathrm{C} 2 / \mathrm{C} 5=1: 3$

aWithout ligand: $11 \%, \mathrm{C} 2 / \mathrm{C} 5=2.4: 1$.

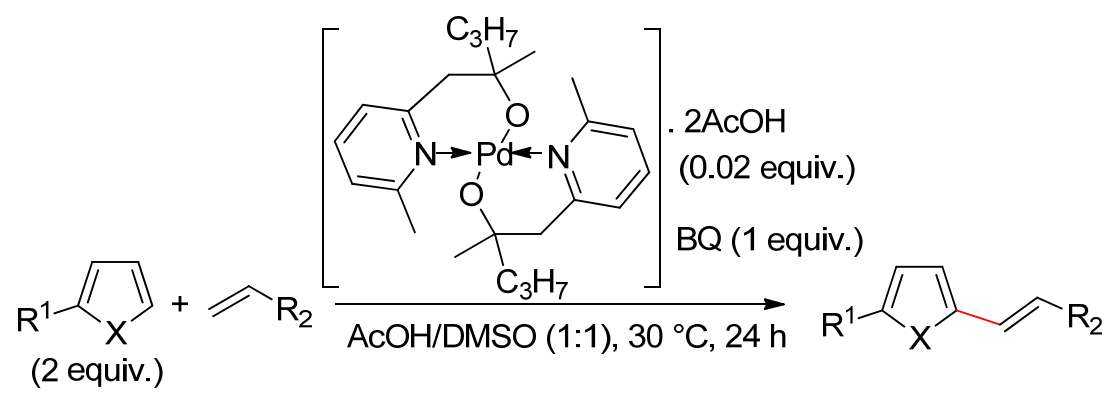

$\mathrm{X}=\mathrm{S}, 20$ examples, $\mathrm{R}^{1}=\mathrm{Me}, \mathrm{R}^{2}=\mathrm{Ph}(95 \%)^{\mathrm{a}, \mathrm{b}, \mathrm{c}}, m-\mathrm{ClC}_{6} \mathrm{H}_{4}(80 \%), \mathrm{CH}=\mathrm{CHCO}_{2} \mathrm{Et}(98 \%)$

$\mathrm{R}^{1}=\mathrm{Br}, \mathrm{R}^{2}=\mathrm{Ph}(70 \%), m-\mathrm{ClC}_{6} \mathrm{H}_{4}(83 \%), \mathrm{CH}=\mathrm{CHCO}_{2} \mathrm{Et}(80 \%)$

$\mathrm{X}=\mathrm{O}, 4$ examples, $\mathrm{R}^{1}=\mathrm{Et}, \mathrm{R}^{2}=\mathrm{Ph}(81 \%), \mathrm{CH}=\mathrm{CHCO}_{2} \mathrm{t}-\mathrm{Bu}(70 \%)$

aOther oxidants: $\mathrm{Ag}_{2} \mathrm{CO}_{3}(40 \%), \mathrm{Cu}(\mathrm{OAc})_{2}$ (trace), $\mathrm{K}_{2} \mathrm{~S}_{2} \mathrm{O}_{8}$ (trace).

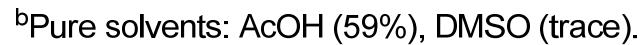

${ }^{\mathrm{c} C a t a l y s t}$ with $\mathrm{CMePh}$ instead of $\mathrm{CMeC}_{3} \mathrm{H}_{7}: 44 \%$.

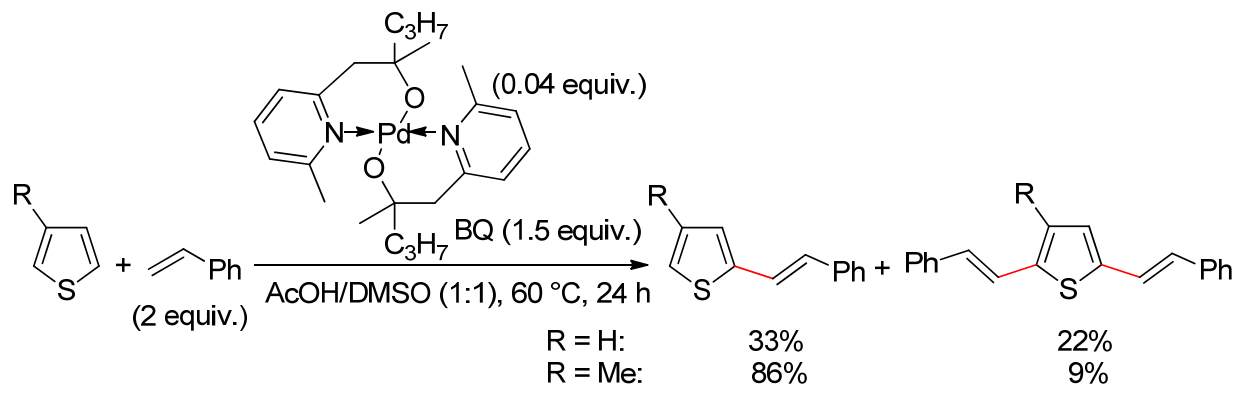




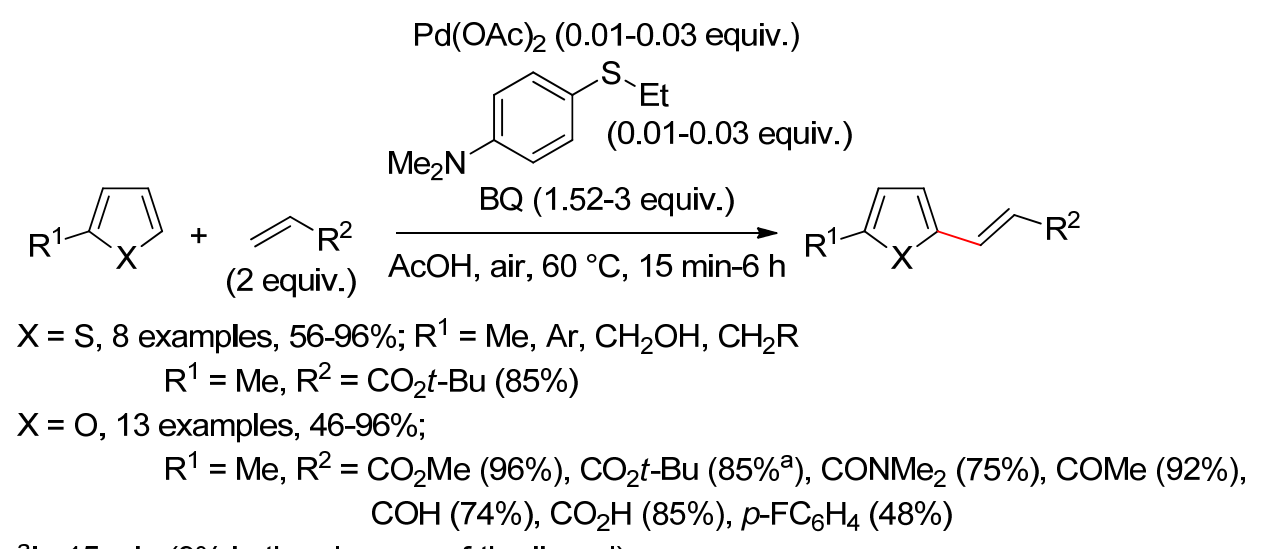

${ }^{\mathrm{a}}$ In $15 \mathrm{~min}$ (9\% in the absence of the ligand).

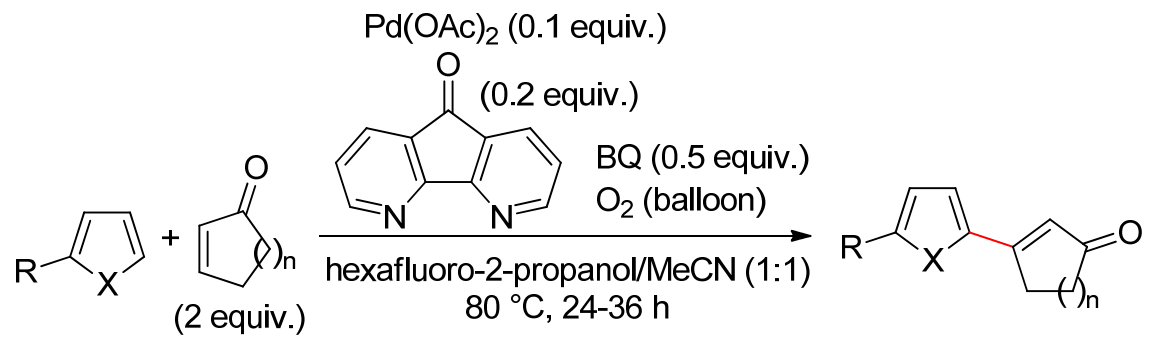

$\mathrm{X}=\mathrm{S}, \mathrm{n}=1,2,3 ; \mathrm{R}=\mathrm{H}, \mathrm{Me}, \mathrm{Ph}, \mathrm{OMe}, \mathrm{COMe}, 7$ examples: $22-75 \%$

$X=O, R=M e, n=2: 54 \%$

The selected ligands, especially 4,5-diazafluorenone [24], sodium 3-((4-methoxyphenyl)thio)propane1-sulfonate, and 4-(ethylthio)- $N, N$-dimethylaniline [45], improve the stability of the catalyst and, consequently, the yields (Equations (7) and (13)), and also the selectivity (Scheme 2) [45].

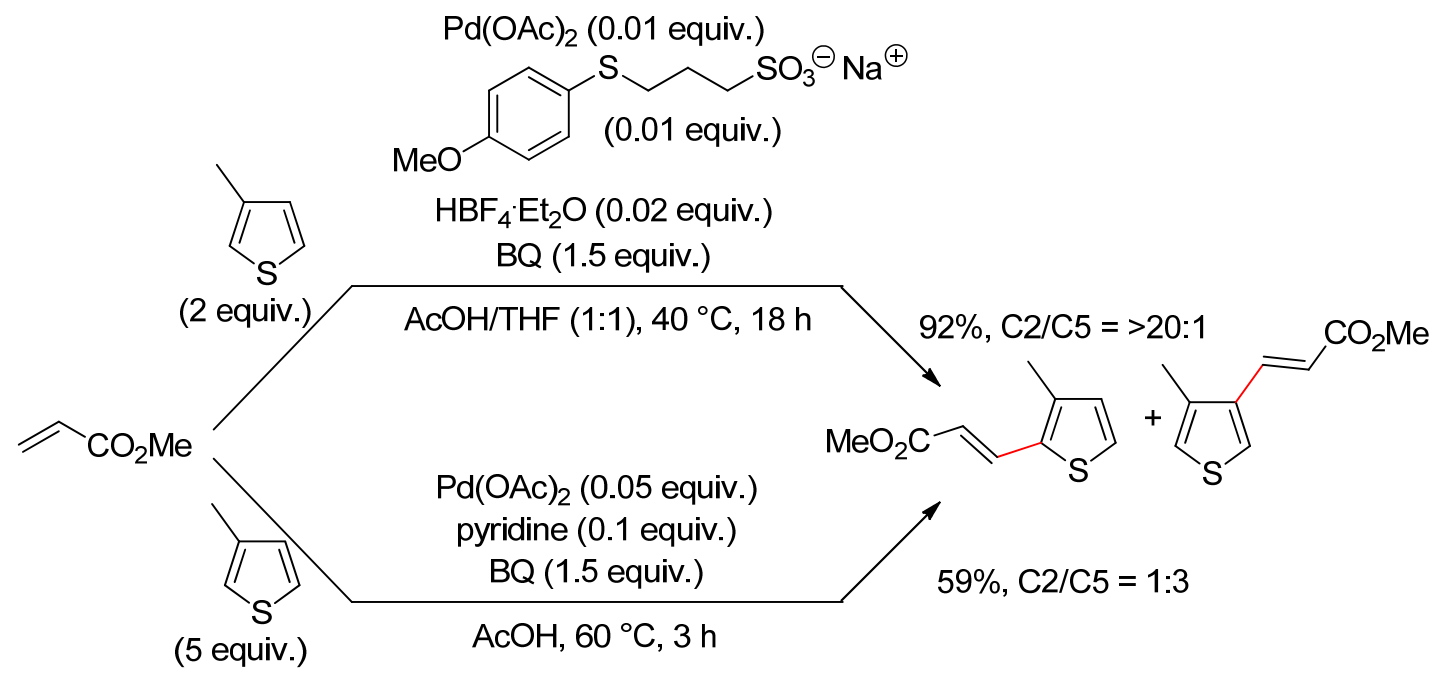

Scheme 2. Carrow's regiodivergent Dehydrogenative Heck Reactions (DHRs).

Jia, $\mathrm{Xi}$, and coworkers prepared a heterogeneous catalyst from deposition of $\mathrm{PdCl}_{2}$ onto the surface of $\mathrm{MoS}_{2}$ nanosheets [47]. Small amounts of this catalyst mediated the effective C5 alkenylation of 3-ethylthiophene in DMF with $\mathrm{Cu}(\mathrm{OAc})_{2}$ as oxidant (Equation (15)). The authors did not comment on the catalyst recyclability. Recently, De Vos' team prepared a palladium-organic framework (noted Pd@ MOF-808-L1) from Pd(OAc) ${ }_{2}$ and a metal-organic framework (noted MOF-808-L1) containing S,O-moieties, the latter increasing the catalytic activity of $\mathrm{Pd}^{\mathrm{II}}$ [48]. DHR of 2,6-dimethylanisole with $n$-butyl acrylate showed that the catalytic power of Pd@ MOF-808-L1 was superior to Pd(OAc) 2 (63\% instead of $22 \%$ ) and similar to a mixture of $\mathrm{Pd}(\mathrm{OAc})_{2}$ and MOF-808-L1 added separately. Consequently, 
the mixture was used for alkenylation of five-membered heteroarenes (Equation (16)), but the method was also lacking of recyclability.

$$
\begin{aligned}
& \begin{array}{l}
\mathrm{Z}=\mathrm{S}, \mathrm{R}=\mathrm{CO}_{2} n-\mathrm{Bu}(74 \%), \mathrm{COC}_{5} \mathrm{H}_{11}(82 \%), \mathrm{CONMe}_{2}(64 \%), \mathrm{Ph}(67 \%) \\
\mathrm{Z}=\mathrm{O}, \mathrm{R}=\mathrm{CO}_{2} n-\mathrm{Bu}(82 \%), \mathrm{COC}_{5} \mathrm{H}_{11}(89 \%), \operatorname{CONMe}_{2}(61 \%), \mathrm{Ph}(71 \%)
\end{array} \\
& \mathrm{Pd}(\mathrm{OAc})_{2} \text { (0.05 equiv.) } \\
& \text { MOF-808-L1 (0.05 equiv.) }
\end{aligned}
$$

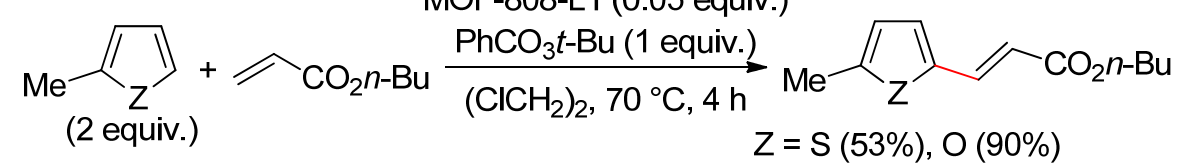

The team of Lin and Yao studied the regiodivergent cross-coupling of 4-arylthiophene-3carboxylates or 4-phenyl-3-acetylthiophene using different metal catalysts [49]. The reaction mainly occurred at $\mathrm{C} 5$ under $\mathrm{Pd}\left(\mathrm{OCOCF}_{3}\right)_{2}$ catalysis, while $\left[\mathrm{RhCp}^{*} \mathrm{Cl}_{2}\right]_{2}$, $\left[\mathrm{RuCl}_{2}(p \text {-cymene })\right]_{2}$ and $\left[\mathrm{IrCp}^{*} \mathrm{Cl}_{2}\right]_{2}$ catalysts led to $\mathrm{C} 2$ products with high regioselectivity (Equation (17)). According to the authors, "the palladium-catalyzed system led to electronic palladation at the more electron-rich C-5 position", while a five-membered metallacycle formed via coordination of $\mathrm{COR}^{2}$ group and $\mathrm{C} 2-\mathrm{H}$ activation is the intermediate leading to $\mathrm{C} 2$ products with other catalysts.

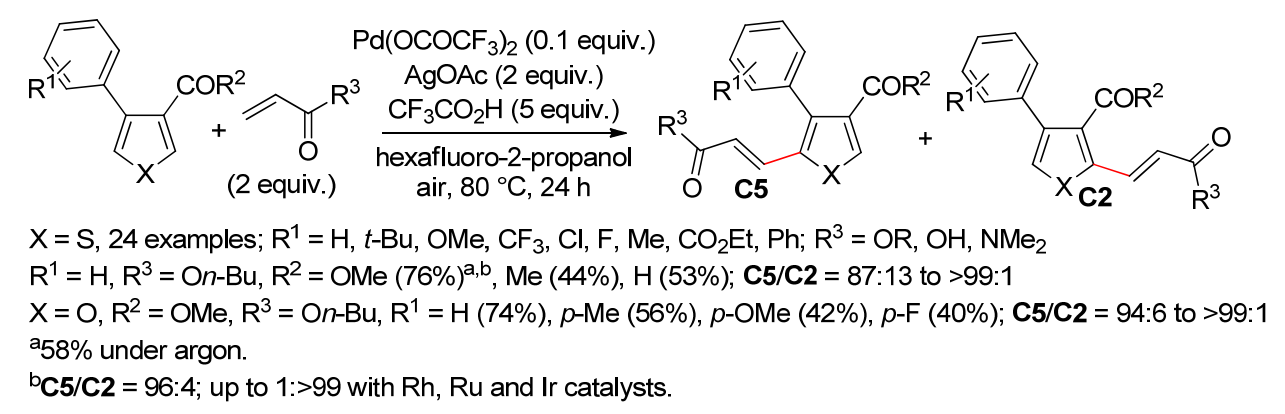

A Catellani-type reaction [50-52] was related by Dong's team, leading to both 5-ethylenation and 4-arylation of 1-substituted thiophenes (Equation (18)) [53]. Sequential stepwise reactions were hypothesized by the authors. That led us to consider the steps of Scheme 3. Insertion of amide-based norbornene NB into the C-Pd bond of heteroarylpalladium intermediate 3A affords 3B. Use of the weak and $\pi$-acidic ligand $\mathrm{AsPh}_{3}$ would prevent formation of $3 \mathrm{C}$ by intramolecular coordination, and allows access to palladacycle 3D. Reaction of 3D with ArI provides $3 \mathrm{E}$ via a putative $\mathrm{Pd}^{\mathrm{IV}}$ intermediate $[50,54]$. $\beta-C$ elimination liberates NB, giving $3 \mathbf{F}$, this step being favored by the size of NB. $3 F$ undergoes reaction with the alkene to deliver the difunctionalized compound.

Subsequent studies of the kinetic profile indicated "that the difunctionalization product was formed immediately at the beginning of the reaction and there was no accumulation of the C4-arylation intermediate during the course of the reaction" [53]. This "coupled" difunctionalization which also occurs for the Catellani diarylation of six-membered aromatic substrates [50,54], led us to suggest an alternative pathway. Exchange of ligand produces $3 \mathrm{G}$ from $3 \mathrm{E}$, which undergoes $\beta-\mathrm{C}$ elimination leading to $3 \mathrm{H}$. Subsequent intramolecular insertion of the alkene followed by reductive elimination affords the compound. According to this pathway, the coordination of the alkene prior to the $\beta-\mathrm{C}$ elimination precludes the release of the C4-arylation product. 


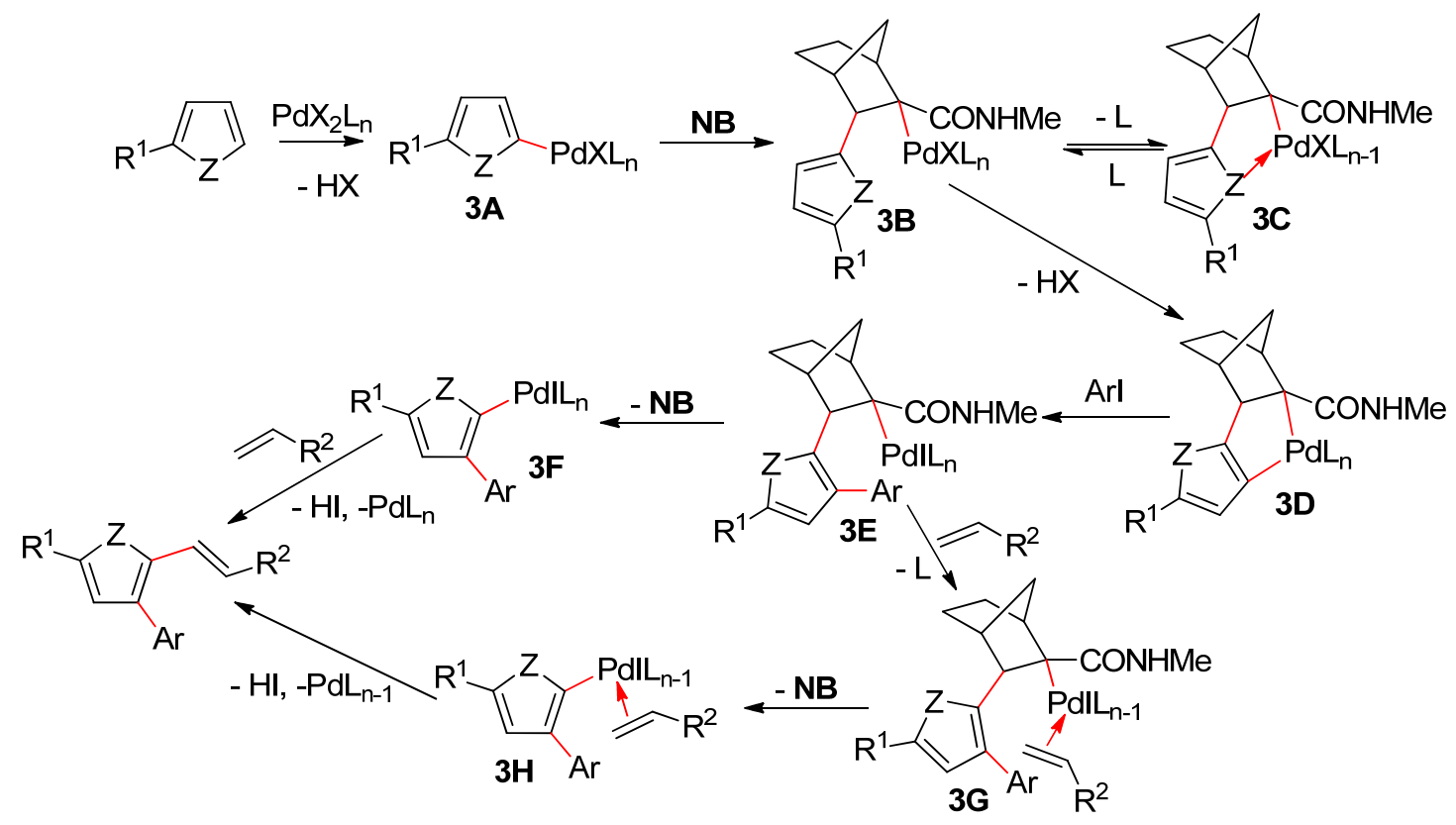

Scheme 3. Plausible pathways of vicinal difunctionalizations.

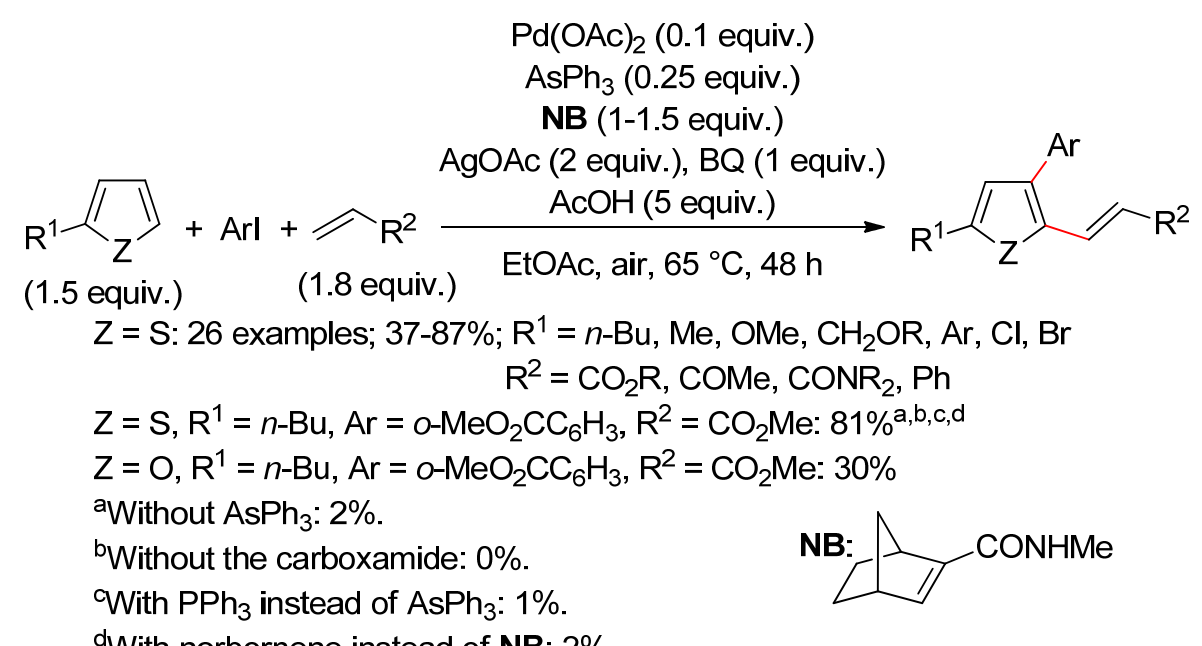

2-Thienyl- $N$-tosylaniline undergoes regioselective DHR with ethyl acrylate leading to the C3 substituted thiophene and a fused heterocycle due, according to Youn and co-workers, to subsequent cyclization of the C3 substituted thiophene (Equation (19)) [55]. We will come back in Sub-chapter 4.1. to the mechanism and catalytic cycle of substrates with a directing group (Scheme 9).

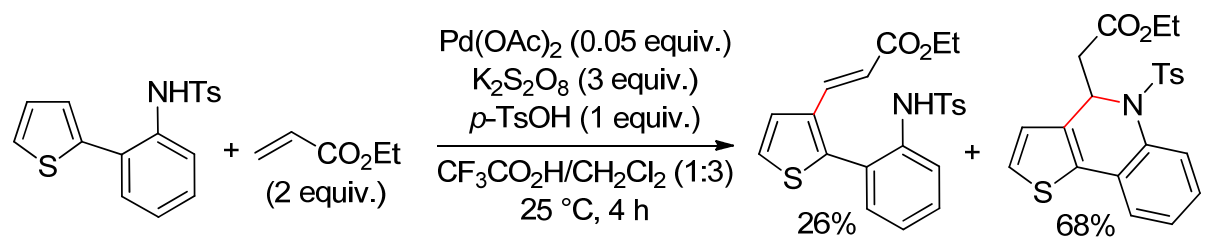




\subsection{Benzothiophenes}

Some of the above procedures have been used for DHRs of benzothiophenes (Equations (20) [37], (21) [40], (22) [45], and (23) [46]). A mixture of C-2 and C-3 cross-coupling products was obtained with allyl acetate and allyl amines, the 2 position being the most reactive (Equations (20) and (21)).

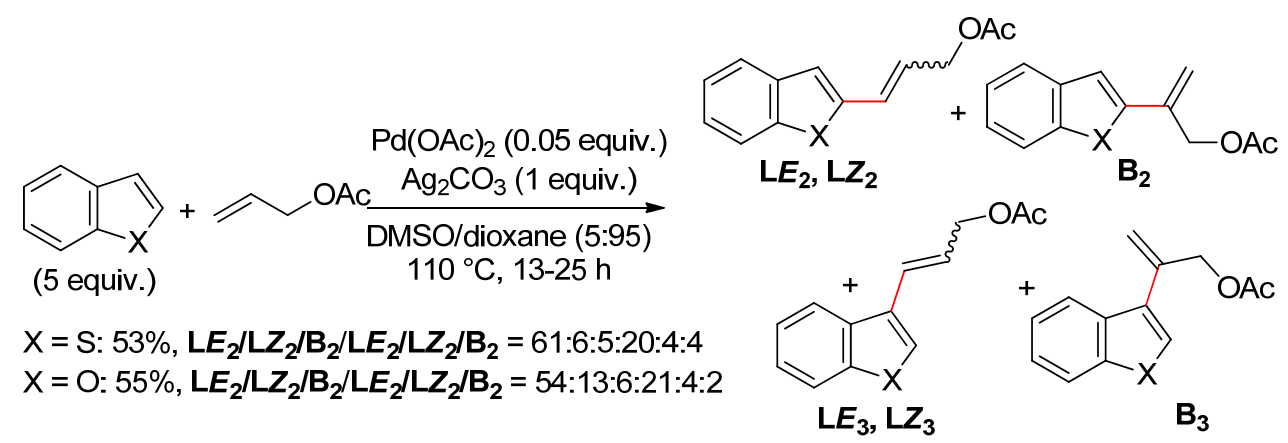

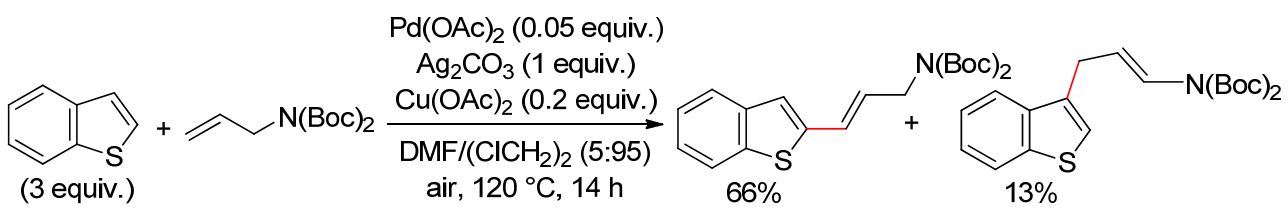

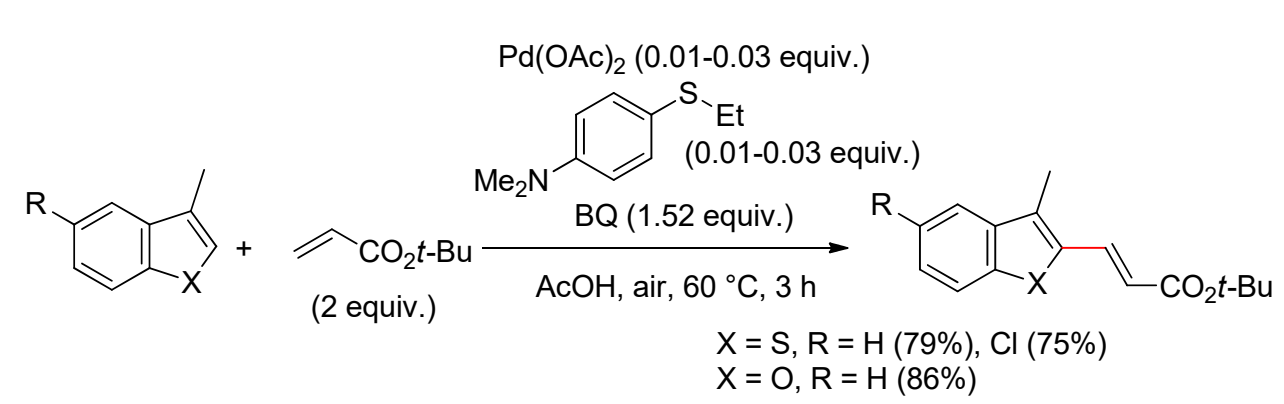

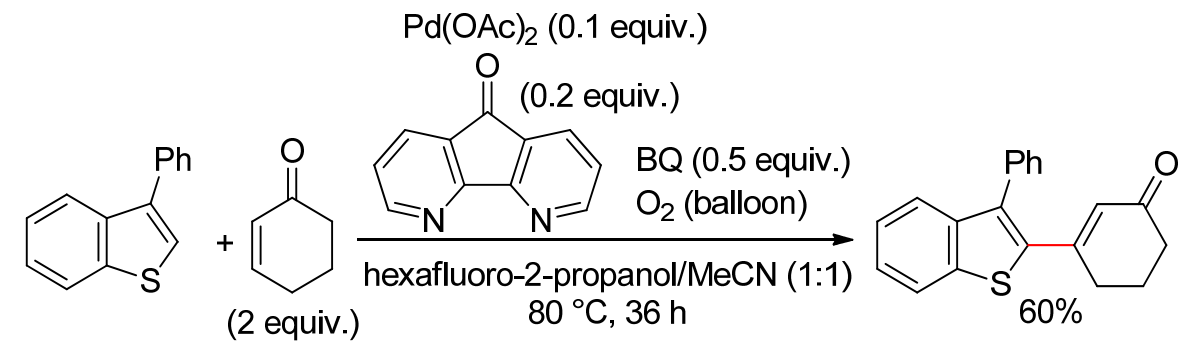

Yu's team disclosed the promotion of DHR's by monoprotected amino acids [56,57]. Such an additive led however to modest yields for the cross-coupling of benzothiophenes with ethyl acrylate, as reported by Huang, Lin, and co-workers, using $\mathrm{Pd}(\mathrm{OAc})_{2}$ combined with 11-molybdovanadophosphoric acid and $\mathrm{N}$-acetylglycine under oxygen [58]. The regioselectivity 
depended on the substituents of the six-membered ring (Equation (24)). The procedure was nevertheless effective for benzofurans (see Equation (32)).

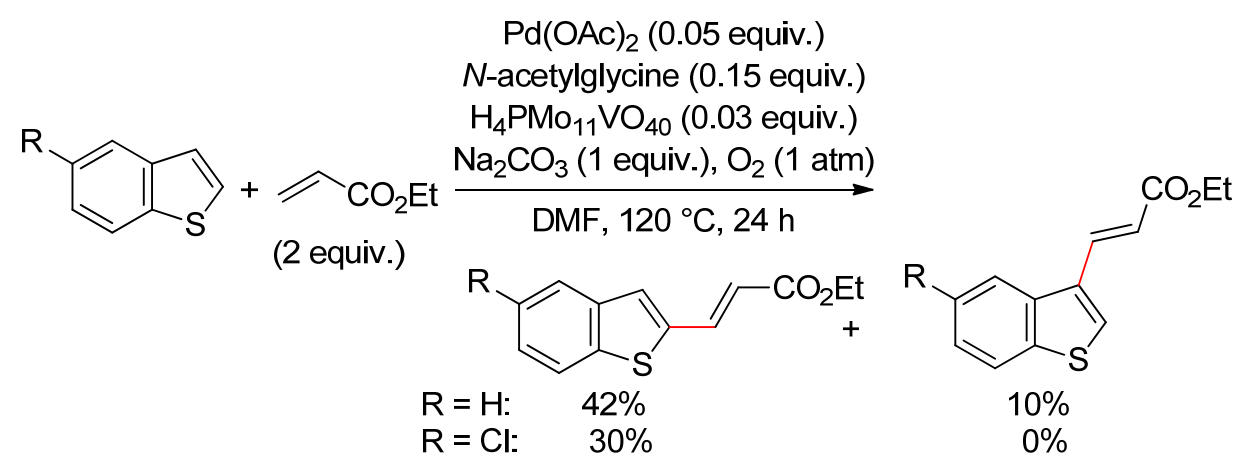

In contrast to the above example, the presence of $N$-acetylvaline allowed high yields of the $\mathrm{Pd}(\mathrm{OAc})_{2}$-catalyzed DHR of 1-(benzo[b]thiophen-2-yl)ethanone $O$-methyl oxime with acrylates (except butyl acrylate) using $\mathrm{AgOCOCF}_{3}$ /air as oxidant (Equation (25)) [59]. Under these conditions, the cross-coupling with styrenes led to domino reactions giving annulation products, in improved yields with pyridine instead of $\mathrm{N}$-acetylvaline (Equation (26)). According to Xia, Ji, and co-workers, the DHR product $4 \mathrm{~A}$ undergoes reaction with the simultaneously formed $\mathrm{Pd}^{0}$, giving $4 \mathrm{~B}$ via oxidative addition to N-O bond $[60,61]$ (Scheme 4). Subsequent amino-Heck reaction provides 4C, which endures $\beta-\mathrm{H}$ elimination, affording the annulation product and $\mathrm{MeOPdH}$. Under the reaction conditions, the latter leads to $\mathrm{Pd}^{\mathrm{II}}$ via, possibly, $\mathrm{Pd}^{0}$.
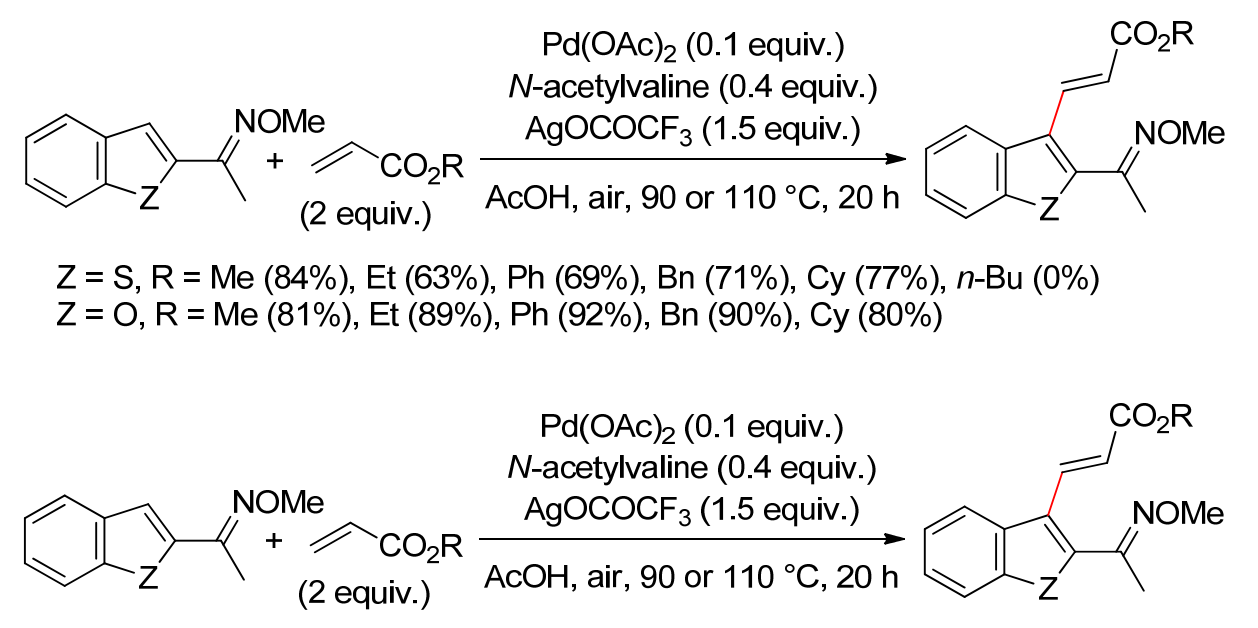

$Z=S, R=M e(84 \%), E t(63 \%), P h(69 \%), B n(71 \%), C y(77 \%), n-B u(0 \%)$

$\mathrm{Z}=\mathrm{O}, \mathrm{R}=\mathrm{Me}(81 \%), \mathrm{Et}(89 \%), \mathrm{Ph}(92 \%), \mathrm{Bn}(90 \%), \mathrm{Cy}(80 \%)$ 


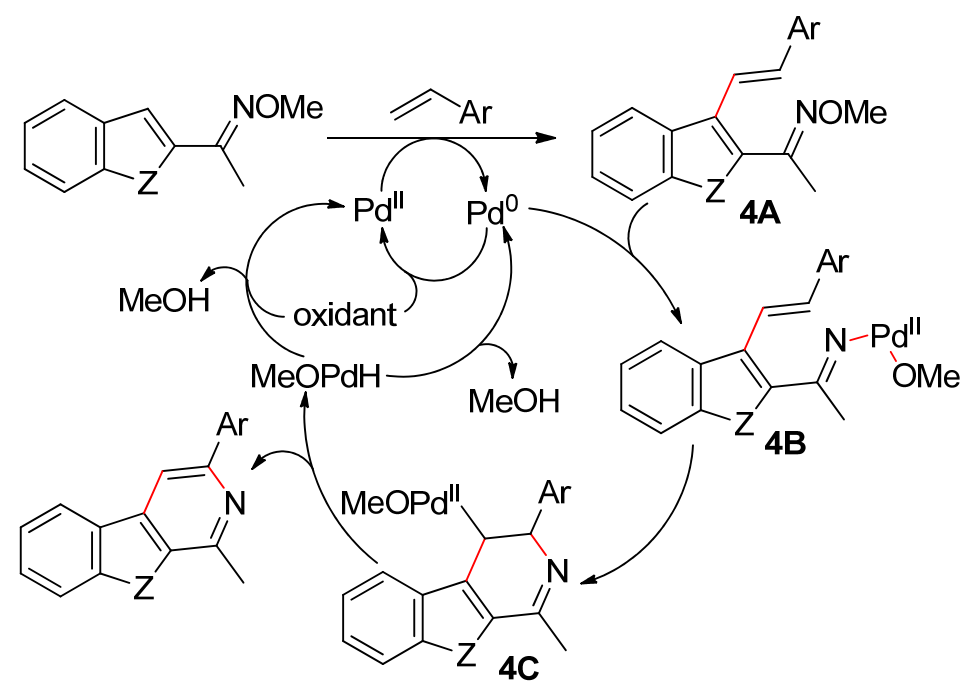

Scheme 4. Annelation via a $\mathrm{Pd}^{\mathrm{II}} / \mathrm{Pd}^{0}$ domino reaction.

\subsection{Thieno[3,2-b]thiophene}

The best results of the $\mathrm{Pd}(\mathrm{OAc})_{2}$-catalyzed $\mathrm{DHR}$ of thienothiophene with styrenes were obtained with $\mathrm{AgOAc}$ in $\mathrm{CF}_{3} \mathrm{CH}_{2} \mathrm{CO}_{2} \mathrm{H}$, while the coupling with acrylates and $\mathrm{N}, \mathrm{N}$-dimethylacrylamide was best carried out with $\mathrm{AgOCOCF}_{3}$ in $\mathrm{EtCO}_{2} \mathrm{H}$ (Equation (27) [62].

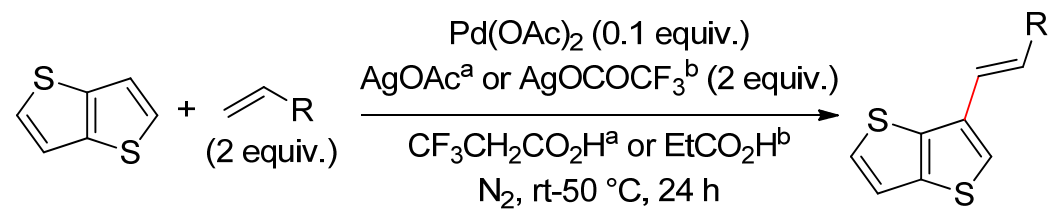

${ }^{\mathrm{a}} \mathrm{R}=\mathrm{Ar}, 5$ examples, $34-76 \%$

$\mathrm{R}=\mathrm{Ph}: 68 \%^{\mathrm{C}}$

${ }^{\mathrm{b}} \mathrm{R}=\mathrm{CO}_{2} \mathrm{R}$ ', $\mathrm{CONMe}_{2}, 7$ examples, $45-60 \%$.

'Other oxidants: $\mathrm{AgOCOCF}_{3}(8 \%), \mathrm{Cu}(\mathrm{OAc})_{2} \cdot \mathrm{H}_{2} \mathrm{O}(5 \%)$.

\subsection{Thieno[3,2-b]furan}

Effective DHR of thieno[3,2-b]benzofuran with styrene and butyl acrylate (Equation (28)) was carried out under conditions of Equation (27) [62].

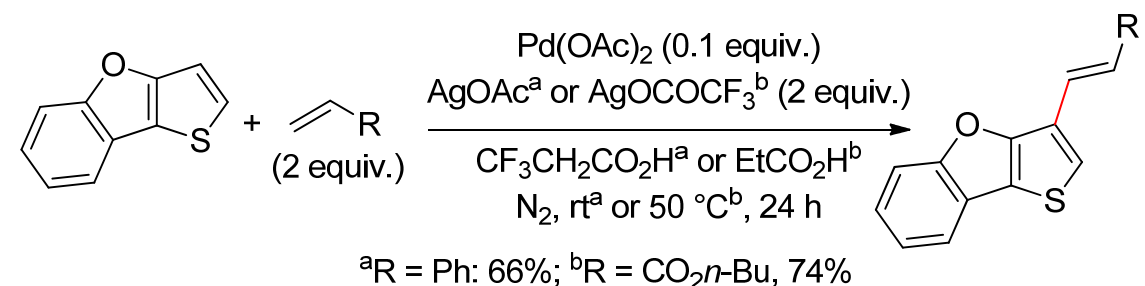

\subsection{Sub-Conclusion}

The 2-position of thiophenes and benzothiophenes is the most reactive towards the DHR. Regiodivergent reaction of thiophenes occurs when the 2- and 5-positions are already substituted or in the presence of a directing substituent. Regioselectivity may also depend on the ligand.

In contrast to thiophenes and benzothiophenes, thienothiophene and thienofuran react in the 3-position. 


\section{O-Arenes}

\subsection{Furans}

Subsequently to the reports by Kasahara's and Fujiwara's teams on the cross-coupling of furans with activated alkenes mediated by stoichiometric amounts of $\mathrm{Pd}(\mathrm{OAc})_{2}$ in refluxing $\mathrm{AcOH}$ [63] or $\mathrm{AcOH} /$ dioxane [29], Kozhevnikov disclosed catalytic conditions with $\mathrm{Cu}(\mathrm{OAc})_{2}$ to regenerate active $\mathrm{Pd}$ species [30]. Increased catalyst turnovers were subsequently reported with $\mathrm{Cu}(\mathrm{OAc})_{2} / \mathrm{O}_{2}[31,64]$, $\mathrm{Cu}(\mathrm{OAc})_{2}$ /air [32], benzoquinone (BQ), $\mathrm{Cu}(\mathrm{OAc})_{2} / \mathrm{BQ} / \mathrm{O}_{2}$ [65], $\mathrm{H}_{6} \mathrm{PMo}_{9} \mathrm{~V}_{3} \mathrm{O}_{40} /$ air [33], $\mathrm{HPMo} 11$ V/air [34], $\mathrm{BQ} / \mathrm{t}-\mathrm{BuOOH}$ [66], $\mathrm{AgOAc}$ [35], or $\mathrm{PhCO}_{3} t-\mathrm{Bu}$ [67] as oxidants with various additives and solvents [10].

Most of the above DHR methods of thiophenes were also used for the reaction of furans (Equation (1) [37], Equation (3) [22], Equations (4) and (5) [40], Equation (6) [41], Equation (7) [24], Equation (12) [44], Equation (13) [45],Equation (14) [46], Equation (15) [47], Equation (16) [48], Equation (17) [49], and Equation (29) [46]). The difunctionalization of 2-butylfuran was also carried out (Equation (18)) [53].

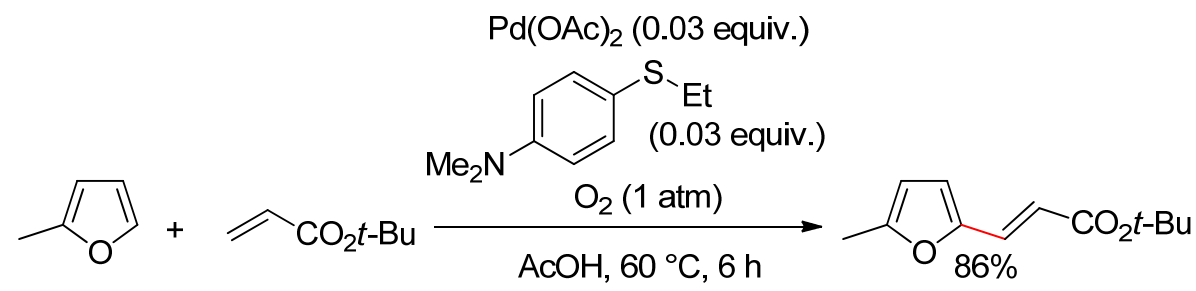

We efficiently carried out the above DHR using BQ as oxidant, at room temperature, in $\mathrm{AcOH} / \mathrm{DMSO}$ (Equation (30)) [21]. Slight homo-coupling of the furan was concomitantly observed.

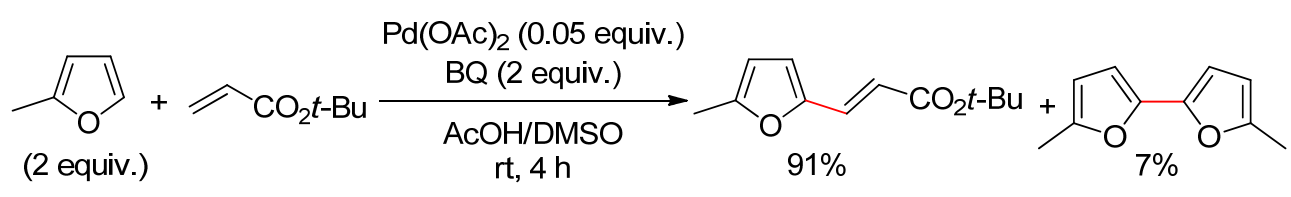

Recently, Zhu's team disclosed an efficient dual ligand-promoted DHR of aryl ethers, and applied their method to the dehydrogenative cross-coupling of furan with acrylonitrile [68]. The modest yield (Equation (31)) indicates that the sophisticated experimental conditions of the method are not adequate for such a substrate.

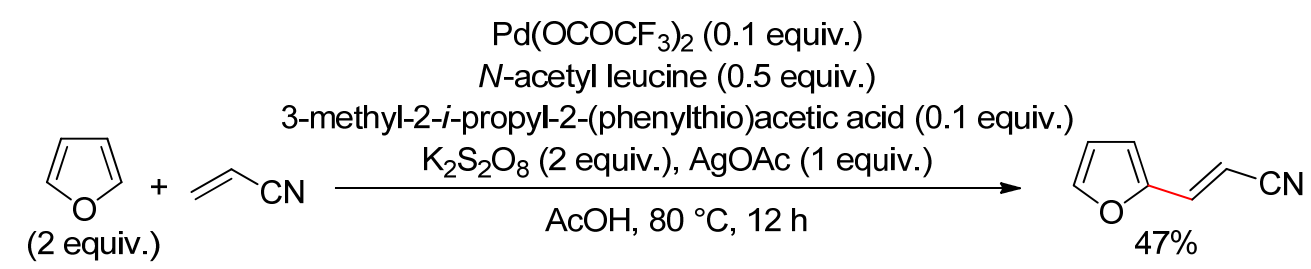

\subsection{Benzofurans}

In most cases, reports of the DHRs of benzothiophenes also provided DHRs of benzofurans (Equation (20) [37], Equation (22) [45], Equation (25), and Equation (26) [59]). Although N-acetylglycine 
was not effective for the DHR of benzothiophenes using $\mathrm{Pd}(\mathrm{OAc})_{2} / \mathrm{H}_{4} \mathrm{PMo}_{11} \mathrm{VO}_{40} / \mathrm{O}_{2}$ (Equation (24)), this additive may mediate fair to high yields from benzofurans (Equation (32)) [58].

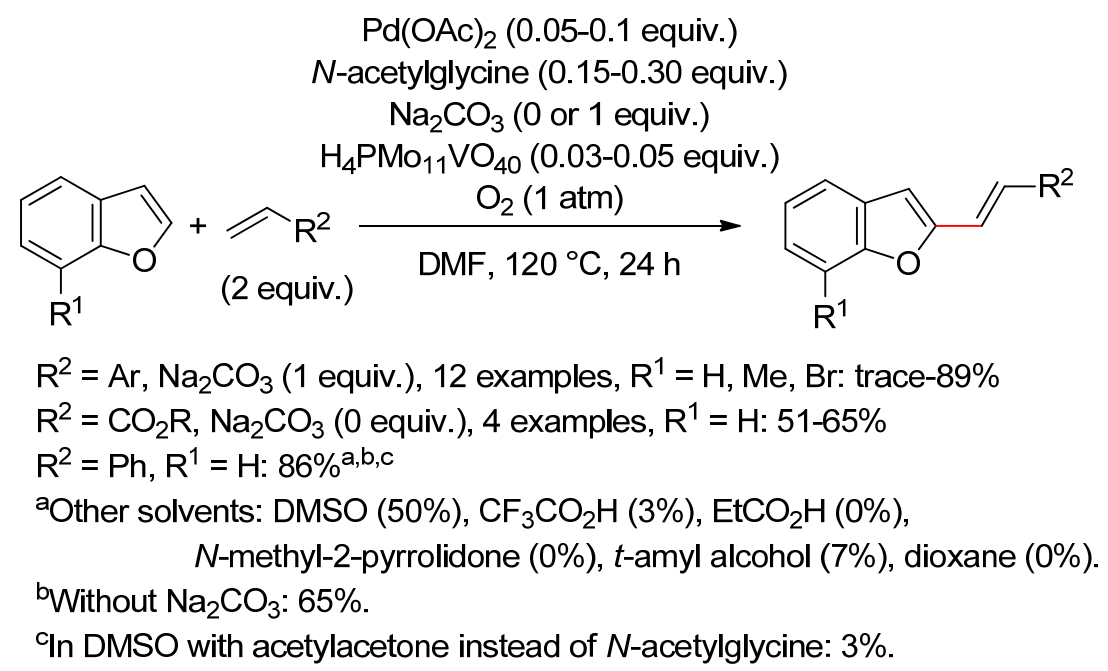

\subsection{Sub-Conclusion}

The exchange of the $\mathrm{S}$ atom for the $\mathrm{O}$ atom has no effect on the DHR regioselectivity of the five-membered heterocycle, the 2-position of furans and benzofurans being the most reactive in the absence of particular substituents.

\section{N-Arenes}

\subsection{Pyrroles}

In 1973, Fujiwara's team disclosed the synthesis of 2- and 3-styryl- $N$-methylpyrroles from stoichiometric amounts of $\mathrm{N}$-methylpyrrole, styrene, and $\mathrm{Pd}(\mathrm{OAc})_{2}$ in refluxing $\mathrm{AcOH} /$ dioxane [29]. Various catalytic conditions are related in our 2011 review [10].

The regioselectivity of the alkenylation of 4-aryl- $1 \mathrm{H}$-pyrrole-3-carboxylates is highly dependent on the solvent (Scheme 5) [69,70]. In benzene, assisted chelation by the carboxylate would favor the formation of $6 \mathbf{A}$ (Scheme 6). DMSO which is a strong coordinating solvent would add to $\mathrm{Pd}(\mathrm{OAc})_{2}$ to afford 6B [71]. That overrides the chelation with the carboxylate and promotes the palladation at $\mathrm{C} 5$ position giving $6 \mathrm{C}$ as intermediate. Subsequent reaction of $6 \mathrm{~A}$ and $6 \mathrm{C}$ with the alkenylating agent affords the two DHR products (Scheme 1).

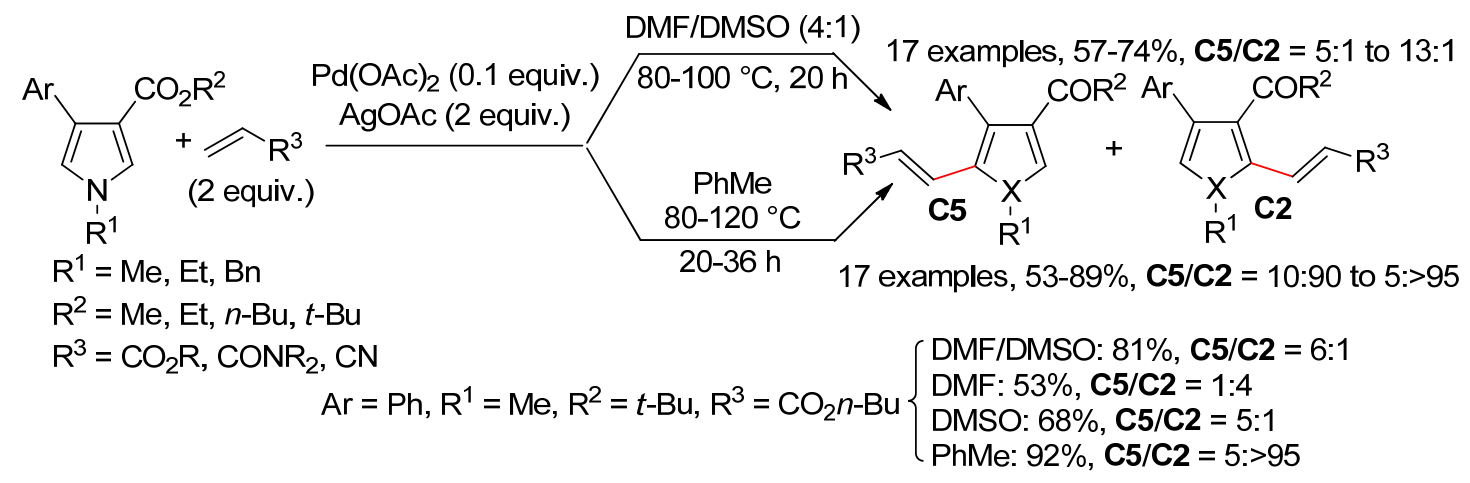

Scheme 5. Lin and Yao's regiodivergent DHRs. 


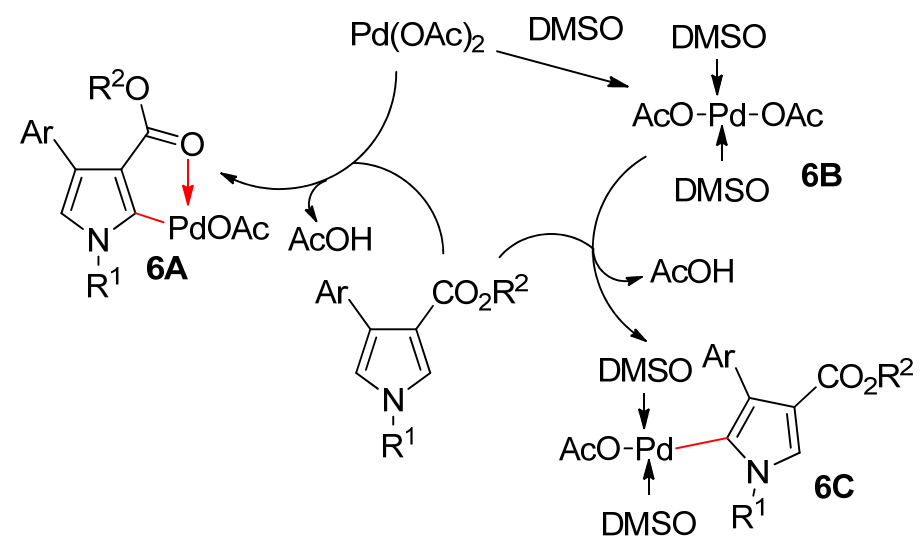

Scheme 6. Regioselectivity depending on intra- or inter-coordination.

The DHR with $\mathrm{Pd}(\mathrm{OAc})_{2} / \mathrm{Cu}(\mathrm{OAc})_{2}$ in DMSO of free $(\mathrm{NH})$-pyrrole occurred in $\mathrm{C} 2$ and $\mathrm{C} 5$ positions, while $\mathrm{N}$-tosylpyrrole afforded the mono-adduct (Equation (33)) [72]. In contrast, free (NH)-pyrrole with an electron-withdrawing C2 substituent led to alkenylation in C4 position (Equation (34)). The same regioselectivity was observed from $N$-methyl, $N$-benzyl, and $N$-tosylpyrroles, the latter reacting under different conditions (Equation (34)). Subjected the cross-coupling products to a second DHR led to C5 substitution with, in the case of the tosylpyrrole, a domino reaction leading to an indole (Scheme 7).
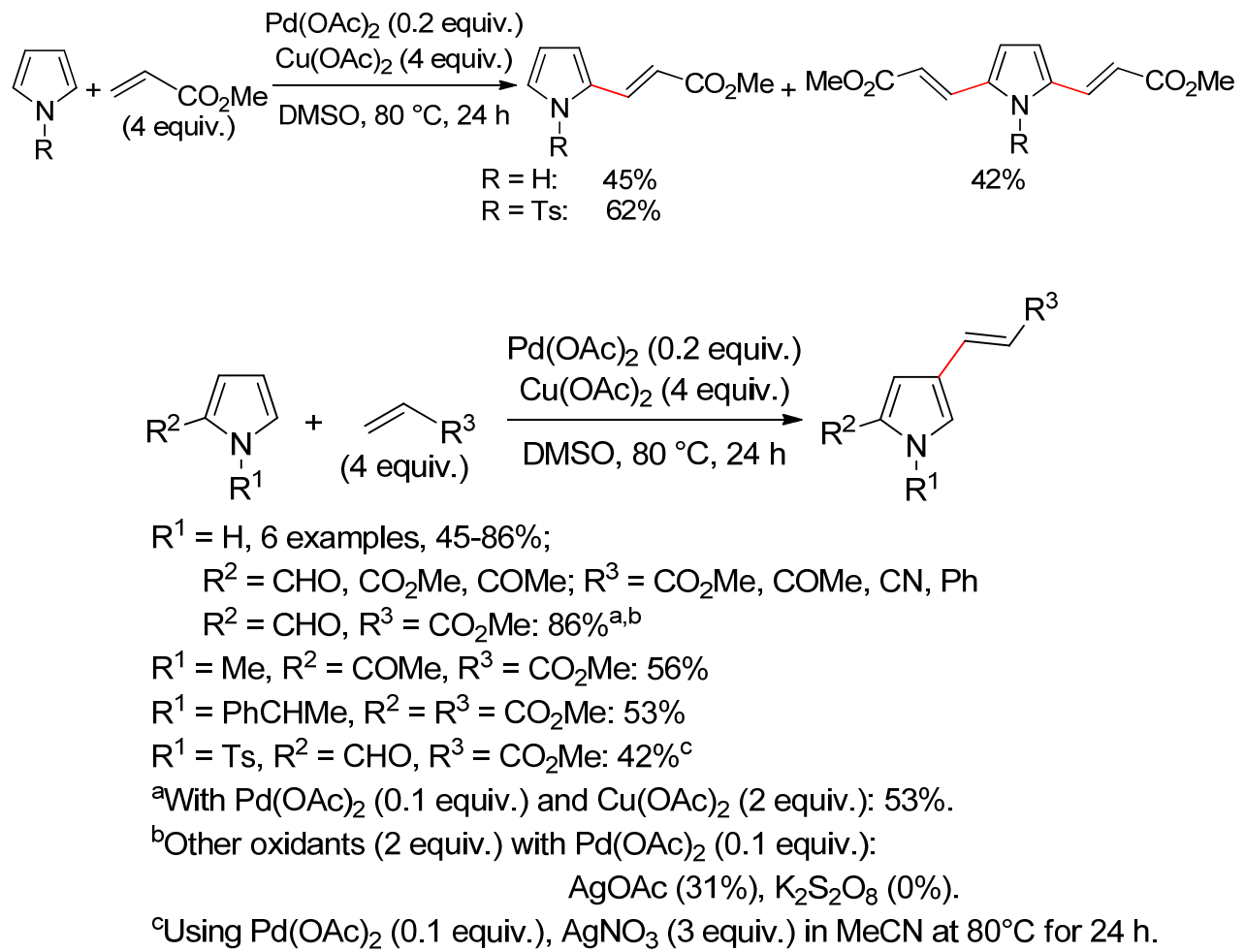

In contrast to the above, the DHR of $\mathrm{N}-\left(p-\mathrm{NCC}_{6} \mathrm{H}_{4} \mathrm{CO}\right)$-2-acylpyrroles mainly occurred at the $\mathrm{C} 5$ position (Equation (35)) [73]. According to Sun and co-workers, the carbonyl of the protecting group 
could have a directing effect but "should not be dominant for this C5-alkenylation". We suspect a C5 selectivity favored by coordination of the nitrile moiety to Pd-intermediates.

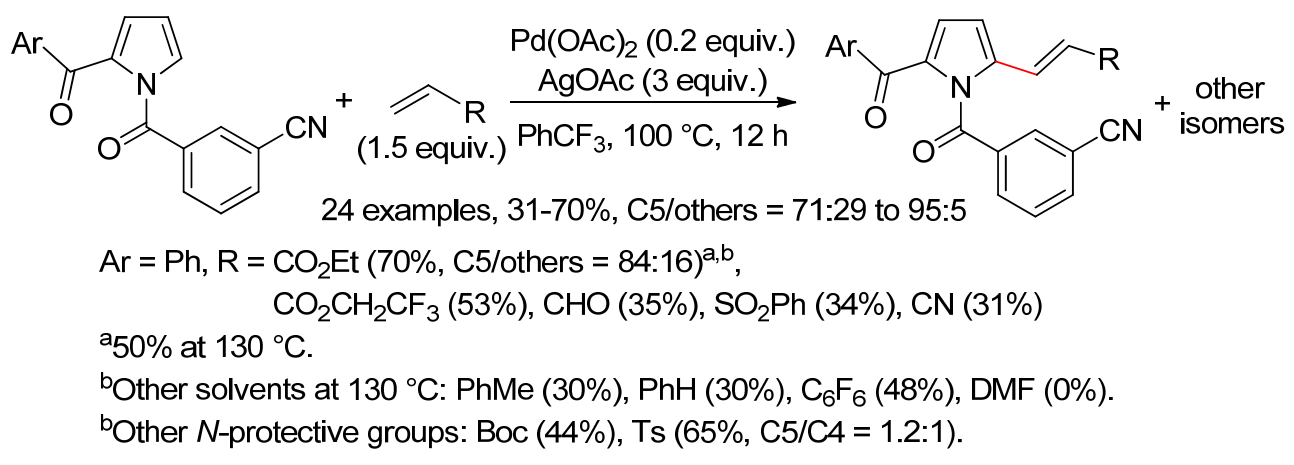

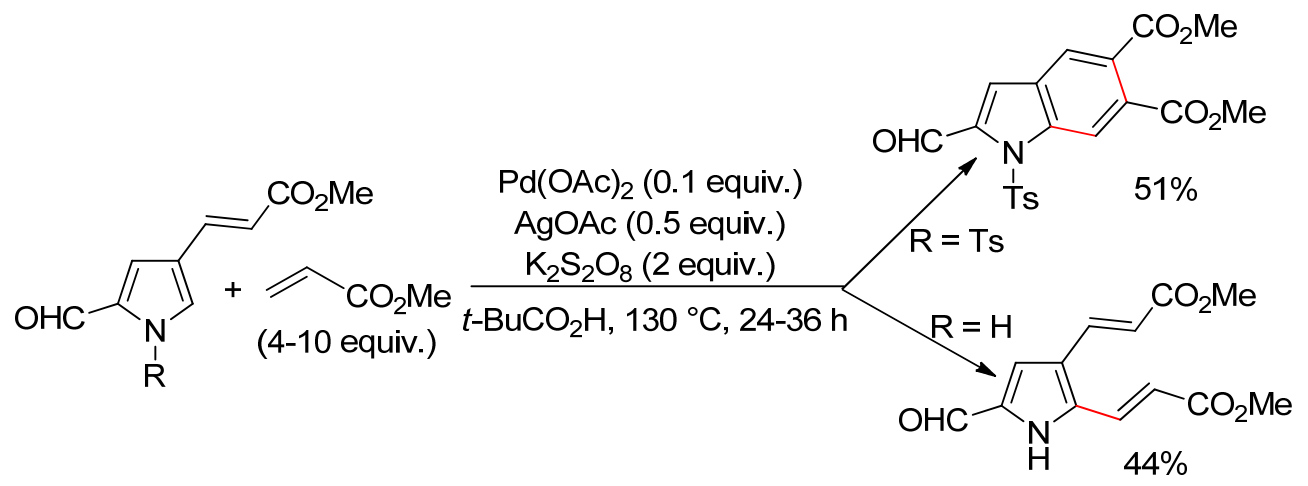

Scheme 7. Domino reaction or not depending on N substitution.

The thioether previously used as additive (Scheme 2) also participated in the DHR of N-protected pyrroles (Equation (36)), directing the reaction to the 5-position of 2-phenyl-pyrroles (Scheme 8) [45].

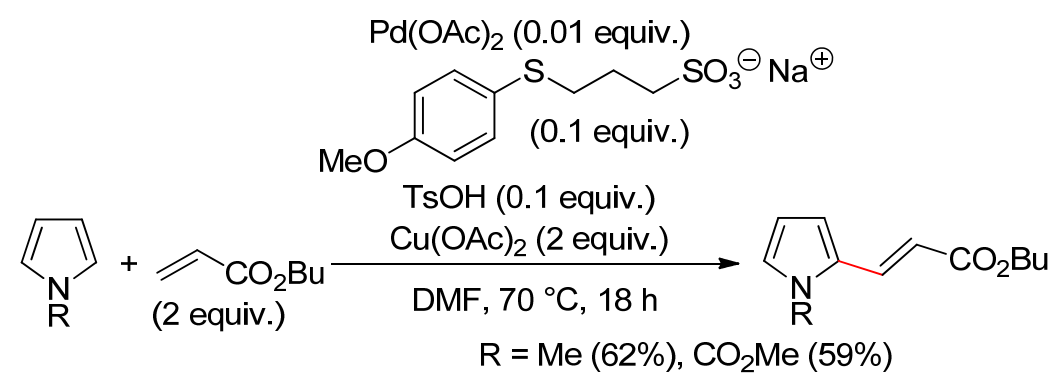

Reaction of $\mathrm{N}$-(2-(1H-pyrrol-1-yl)phenyl)-4-methylbenzenesulfonamide with butyl acrylate provided a quinoxaline derivative (Equation (37)) [74]. According to Xiao, Wang, and co-workers, the reaction pathway begins with the palladation of the secondary nitrogen giving 9A (Scheme 9, this scheme differs from that proposed by the authors [74], and also by Youn's team [55]). Selective activation of the $\alpha-\mathrm{C}-\mathrm{H}$ bond of the pyrrole provides palladacycle $9 \mathbf{B}$. Coordination of the alkenating 
agent followed by insertion into the C-Pd bond affords 9C. Nitrogen-assisted $\beta$-hydrogen elimination leads to 9D. Subsequent hydroamination gives the product.
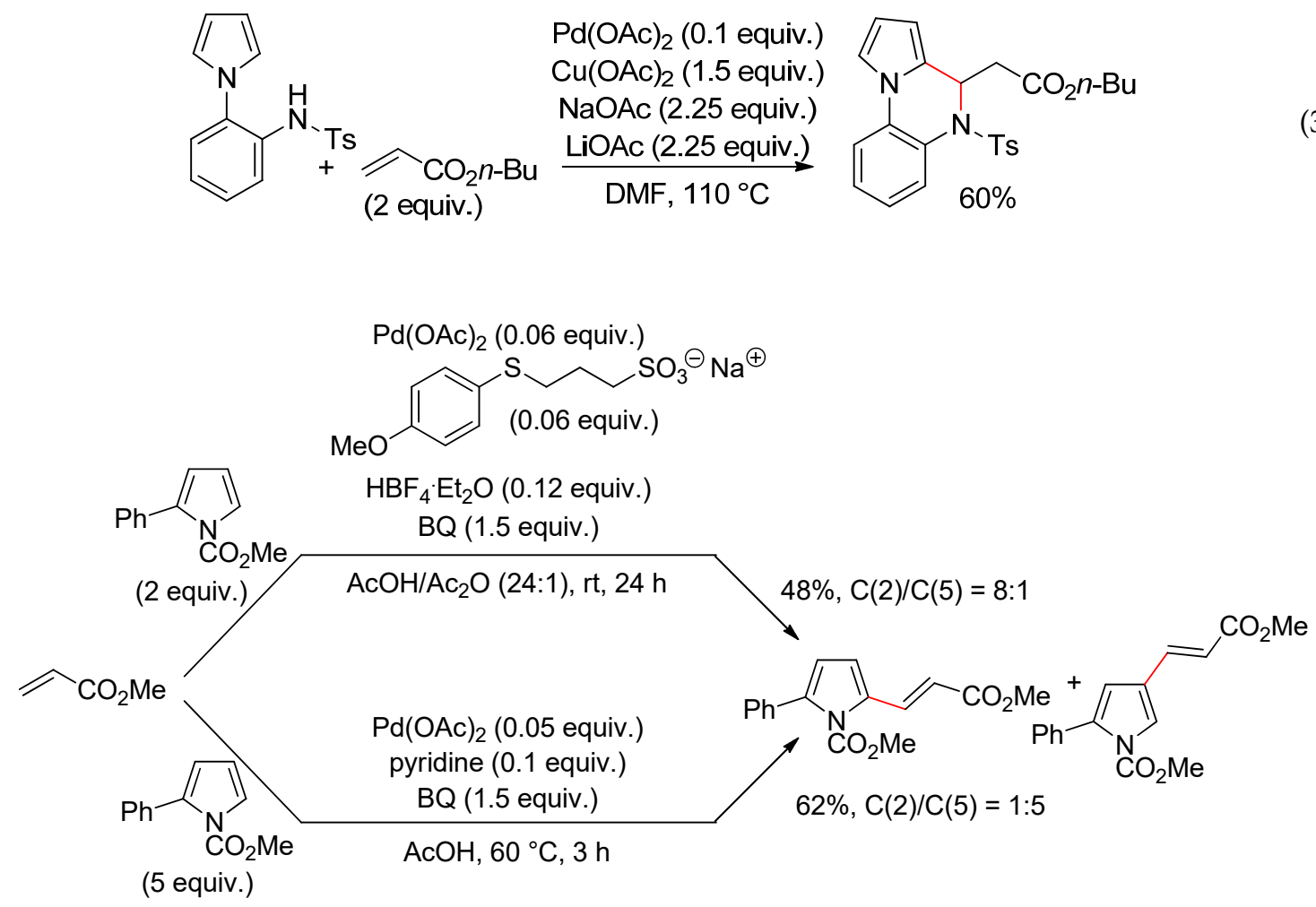

Scheme 8. Carrow's regiodivergent DHRs.

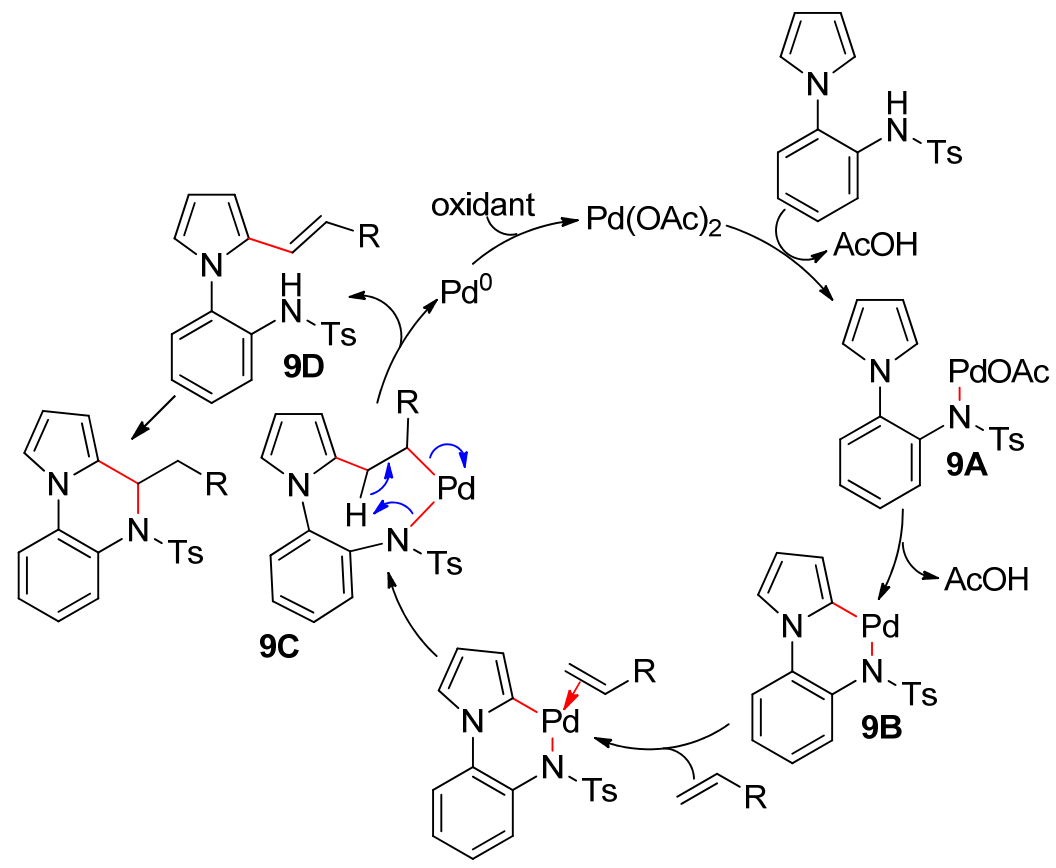

Scheme 9. Annulation of N-(2-(1H-pyrrol-1-yl)phenyl)-4-methylbenzenesulfonamide. 
$\mathrm{Pd}^{\mathrm{II}}$-catalyzed DHRs of boron dipyrromethene derivatives were carried out with either styrenes and $\mathrm{AgOAc}[75]$ or acrylates and $\mathrm{AgOCOCF}_{3}$ (Equation (38)) [76], affording dyes with improved properties.

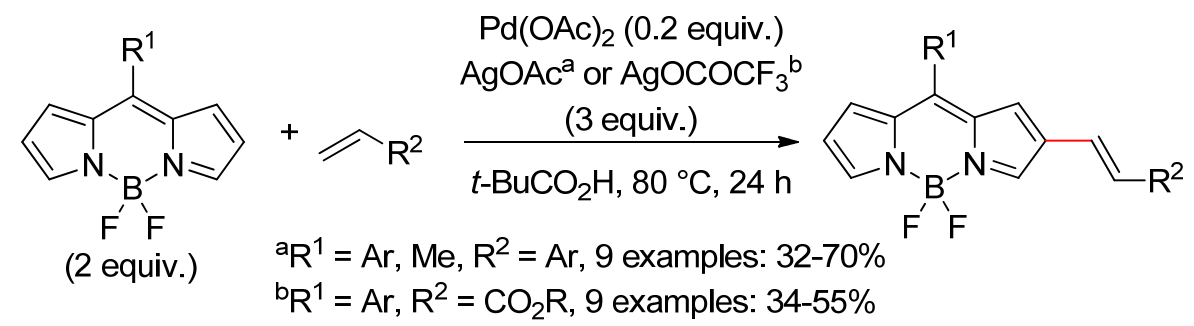

\subsection{Indoles}

Our 2011 review [10] contains a great number of DHRs of indoles. The topic continued to retain the attention of researchers resulting into papers with different $\mathrm{N}$-protecting groups and experimental conditions. Reviews not limited to palladium catalysis and DHR have been published [77-79]. As pointed in the introduction chapter, we will limit the examples to the DHRs of the heterocycle (For reactions at C4, C5, C6, and C7 positions of the benzenoid ring, see [18]).

Before presenting the results of the ten last years, it is necessary to remember the important communication of Gaunt and co-workers who, in 2005, disclosed the selective 2- or 3-alkenylation of free $(\mathrm{NH})$ indoles, depending on the experimental conditions, especially the solvent (Scheme 10) [80]. The optimum conditions also allowed the selective 3-alkenylation of $N$-methyl indole but were ineffective for the $\mathrm{C} 2$. According to the authors, the reaction starts with palladation at $\mathrm{C} 3$. Acidic conditions would allow migration of the C3-Pd bond leading to C2-Pd bond, hence the observed results.

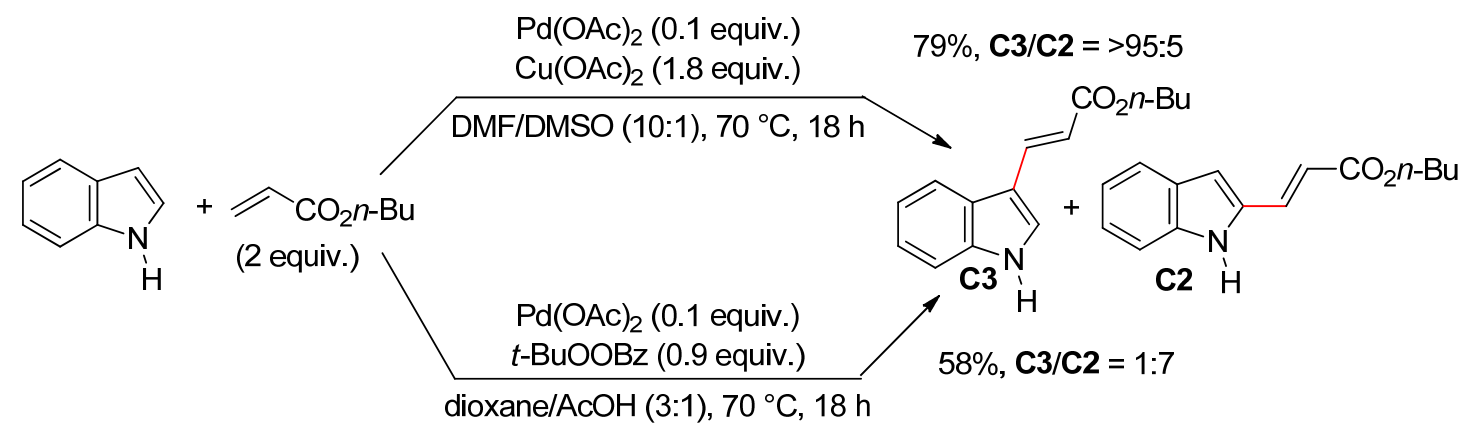

Scheme 10. Gaunt's divergent DHRs.

This chapter is divided in three parts corresponding to reactions in C3, C2, or both C2 and C3 positions.

\subsubsection{C3 Alkenylations}

Some of the above procedures have been used (Equations (39) [22], (40) [47], (41) [45], and (42) [41]). Surprisingly, the addition of metallic co-oxidants may have a negative effect on the aerobic DHR [22]. The $\mathrm{Pd}(\mathrm{OAc})_{2} / \mathrm{MOF}-808-\mathrm{L} 1 / \mathrm{PhCO}_{3} t-\mathrm{Bu}$ procedure (Equation (16)) mainly led to $\mathrm{C} 3$ alkenylation of 1-methyl-1H-indole (Equation (43)) [48]

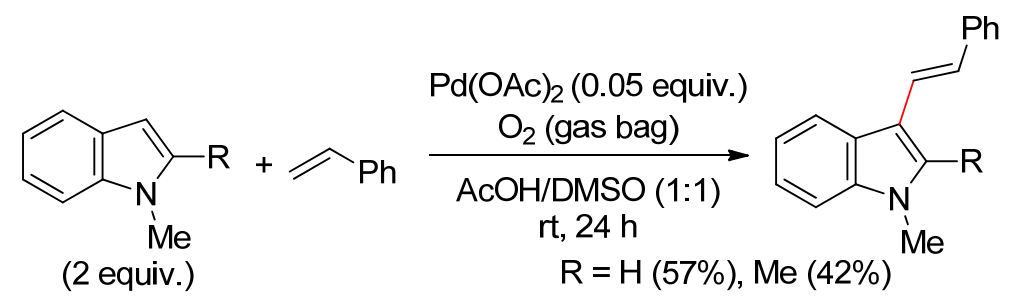




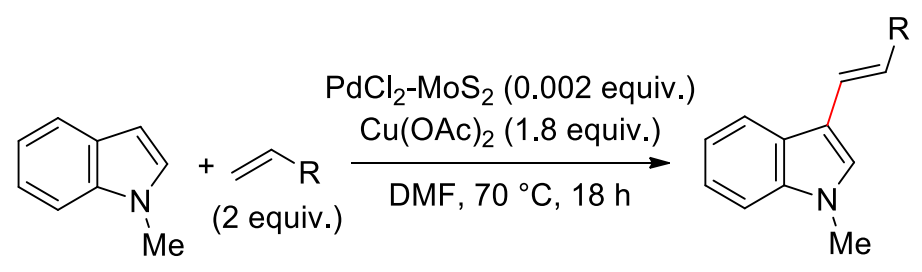

$\mathrm{R}=\mathrm{CO}_{2} n-\mathrm{Bu}(75 \%), \mathrm{Ph}(68 \%), \mathrm{CONMe}_{2}(55 \%), \mathrm{COC}_{5} \mathrm{H}_{11}(84 \%)$

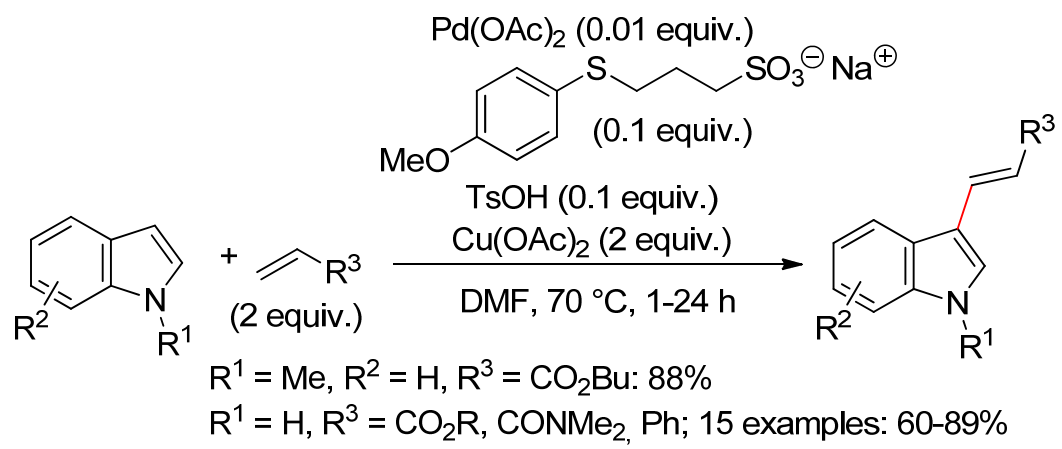

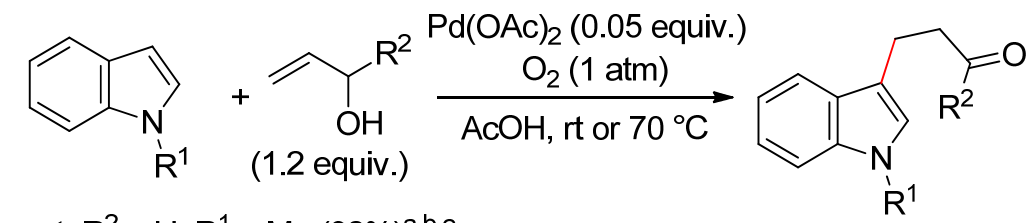

$\mathrm{rt}, \mathrm{R}^{2}=\mathrm{H}, \mathrm{R}^{1}=\mathrm{Me}(92 \%)^{\mathrm{a}, \mathrm{b}, \mathrm{c}}$

$\dot{R}^{1}$

$70{ }^{\circ} \mathrm{C}, \mathrm{R}^{2}=\mathrm{Me}, \mathrm{R}^{1}=\mathrm{Me}(94 \%), \mathrm{Bn}(68 \%)$

aOther solvents: $\mathrm{MeCN}(0 \%)$, DMSO (0\%).

${ }^{\mathrm{b}}$ At $80{ }^{\circ} \mathrm{C}: 73 \%$.

'Other oxidants (1.5 equiv.) at $80^{\circ} \mathrm{C}: \mathrm{Ag}_{2} \mathrm{CO}_{3}(58 \%), \mathrm{Cu}(\mathrm{OAc})_{2}(29 \%)$.

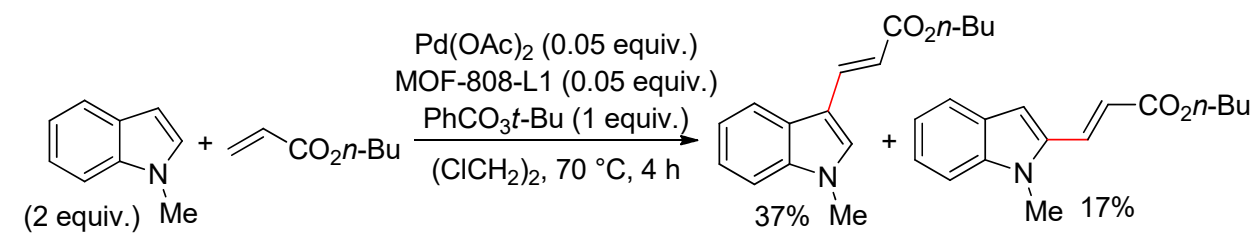

1-methyl-1H-indole

Other aerobic procedures have been proposed.

The $\mathrm{PdX}$ /acid/DMSO method is very sensitive to the nature of $\mathrm{X}$ and the acid, $\mathrm{Pd}(\mathrm{OAc})_{2} / \mathrm{CF}_{3} \mathrm{CO}_{2} \mathrm{H}$ being the optimum (Equation (44)) [81]. The cross-coupling occurred with lower yields in other solvents. In fact, the Pd coordination ability of DMSO could prevent the precipitation of $\operatorname{Pd}^{0}[80,82]$. Although 
$\mathrm{TsOH}$ was ineffective for the $\mathrm{PdX}_{2} /$ acid/DMSO method (Equation (44)), this acid was retain for the DHR in the presence of a thioether ligand (Equation (45)) [45].

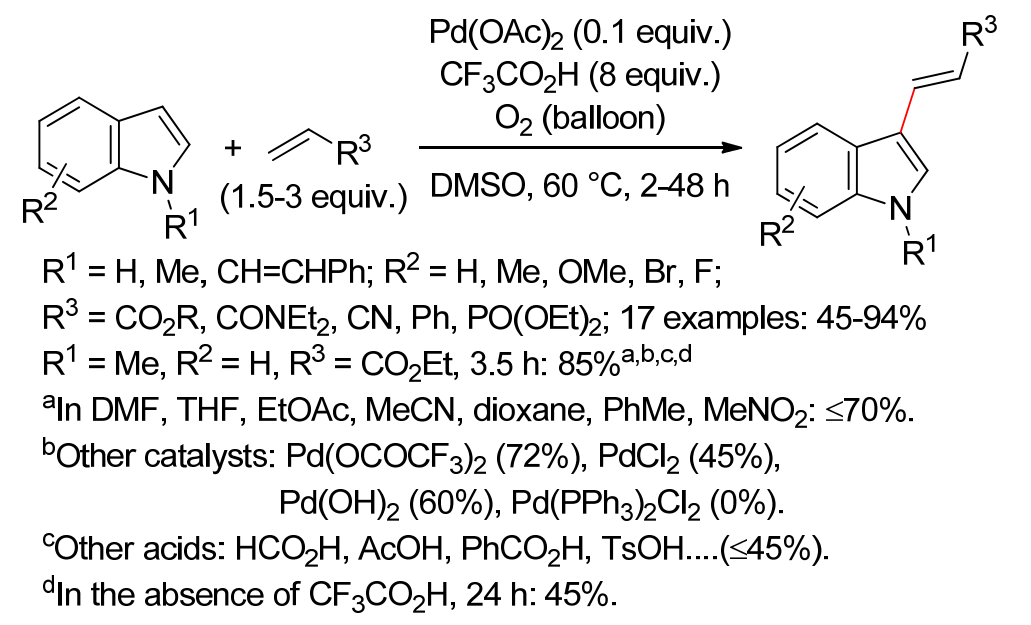

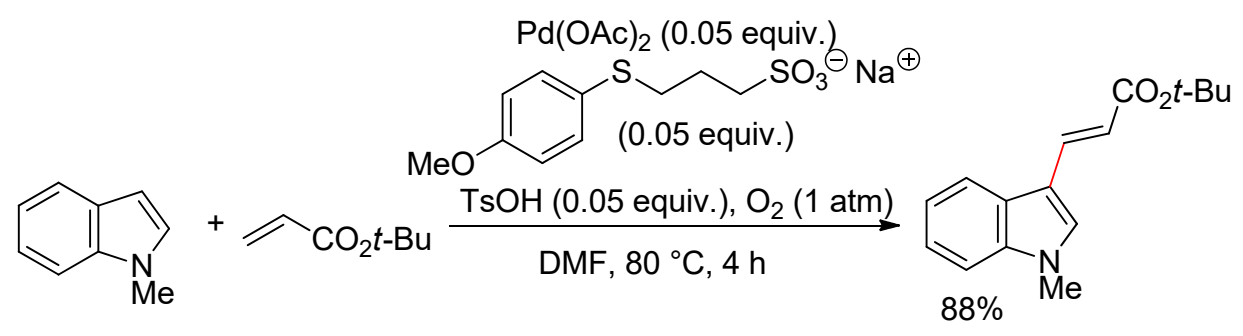

Catalytic amounts of $\mathrm{Pd}(\mathrm{OAc})_{2}$ and a molybdophosphoric acid with 4-dimethylaminopyridine under oxygen pressure in DMF/DMSO led to DHRs of various indoles. All components and solvents have a decisive role on the yields (Equation (46) [83].

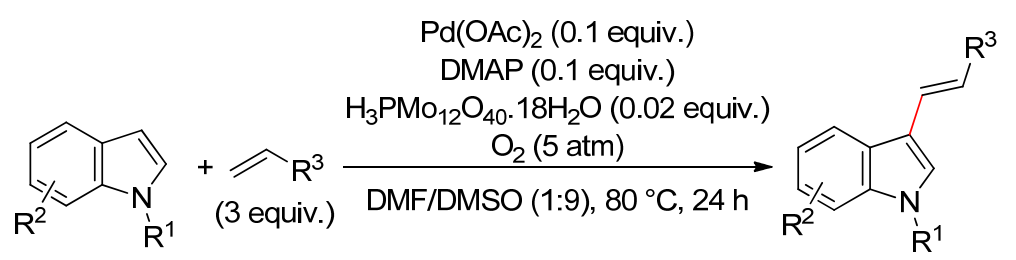

$\mathrm{R}^{1}=\mathrm{H} ; \mathrm{R}^{2}=\mathrm{H}, \mathrm{OMe}, \mathrm{OBn}, \mathrm{Br}, \mathrm{F}, \mathrm{CO}_{2} \mathrm{Me} ; \mathrm{R}^{3}=\mathrm{CO}_{2} \mathrm{R}, \mathrm{PO}(\mathrm{OEt})_{2} ; 15$ examples: 60-88\%

$\mathrm{R}^{1}=\mathrm{H}, \mathrm{R}^{2}=\mathrm{H}, \mathrm{R}^{3}=\mathrm{CO}_{2} n-\mathrm{Bu}: 73 \%$ (GC yield: $85 \%{ }^{\mathrm{a}, \mathrm{b}, \mathrm{c}}$ )

$\mathrm{R}^{1}=\mathrm{Me}, \mathrm{R}^{2}=\mathrm{H}, \mathrm{R}^{3}=\mathrm{CO}_{2} n-\mathrm{Bu}: 64 \%$

aln the absence of DMAP: $13 \%$.

bIn the absence of $\mathrm{H}_{3} \mathrm{PMo}_{12} \mathrm{O}_{40} \cdot 18 \mathrm{H}_{2} \mathrm{O}: 0 \%$.

'Other solvents: DMF (20\%), DMSO (80\%), AcOH (0\%), 1,4-dioxane (trace).

DMF/DMSO was also the solvent mixture for the catalytic DHR of free $(\mathrm{NH})$ indoles with maleimides (Equation (47)) [84]. The DHR of $\mathrm{N}$-methylindole with butyl acrylate arose in fair yield using $\mathrm{PdCl}_{2} / \mathrm{PPh}_{3} / \mathrm{Cu}(\mathrm{OAc})_{2}$ in the solvent mixture (Equation (48) (Under these conditions, free (NH) 
indoles led mainly to annulation products, like those of Equation (61)) [85]. Note that yields may depend on the DMF/DMSO ratio [85].

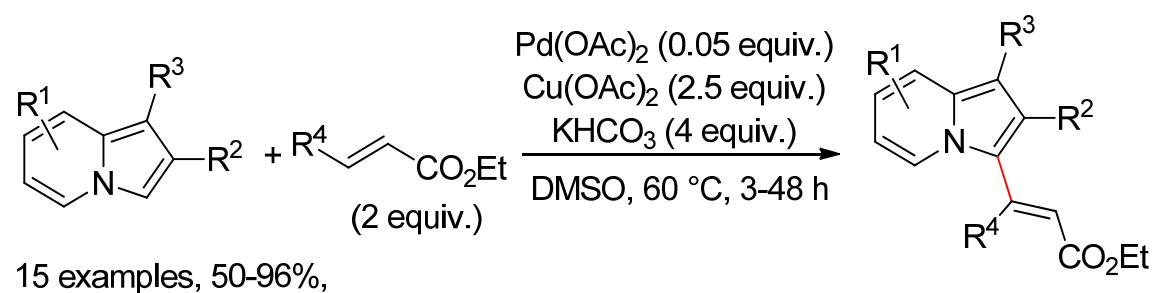

$\mathrm{R}^{1}=\mathrm{H}, \mathrm{Me} ; \mathrm{R}^{2}=\mathrm{H}, \mathrm{CO}_{2} \mathrm{R}, \mathrm{Me}, \mathrm{Ar} ; \mathrm{R}^{3}=\mathrm{H}, \mathrm{CN}, \mathrm{CO}_{2} \mathrm{R}, \mathrm{CONMe}_{2}, \mathrm{COPh} ; \mathrm{R}^{4}=\mathrm{H}, \mathrm{Me}$

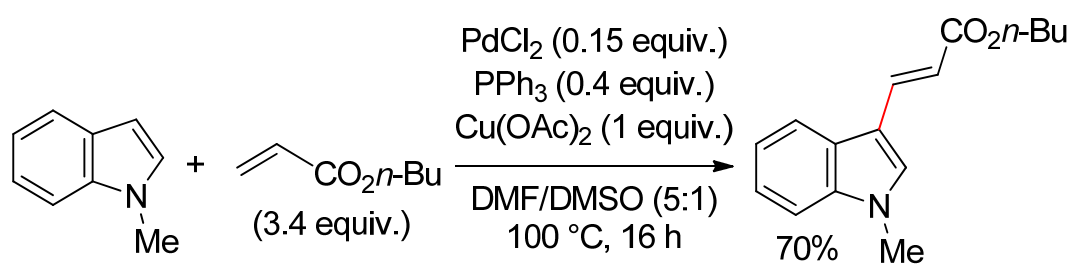

$t$-Butylhydroperoxide associated to catalytic amounts of a heterogeneous copper catalyst has been proposed as reoxidant for the $\mathrm{Pd}(\mathrm{OAc})_{2}$-catalyzed $\mathrm{DHR}$ of free $(\mathrm{NH})$ and $\mathrm{N}$-methylindoles in DMSO (Equation (49)) [86].

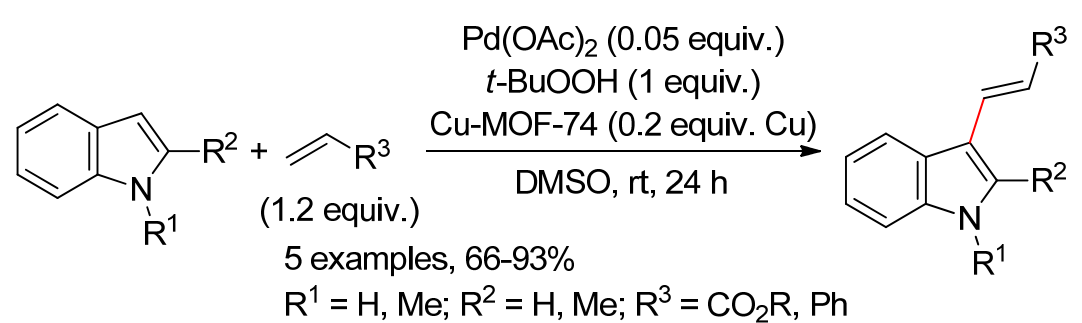

Bolm's team introduced the mechanochemical activation for solventless Rh-catalyzed DHRs [87]. $\mathrm{Su}$ and co-workers used this high-speed ball-milling process for the fast Pd-catalyzed C3 alkenylation of indoles with $\mathrm{MnO}_{2}$ as oxidant (Equation (50)) [25].

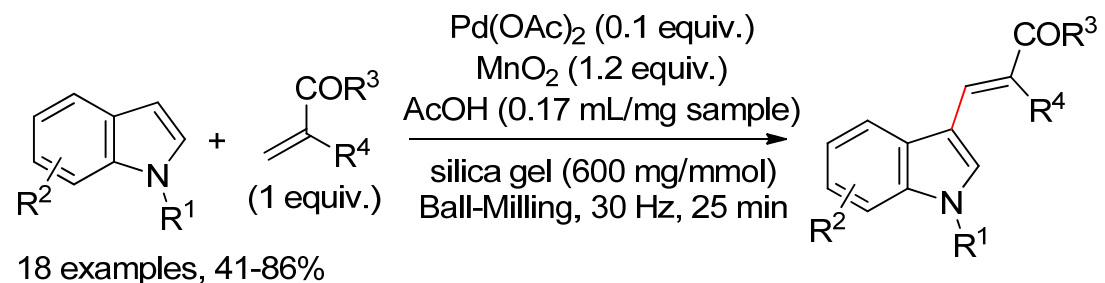

18 examples, $41-86 \%$

$\mathrm{R}^{1}=\mathrm{Me}, \mathrm{Et}, \mathrm{Bn} ; \mathrm{R}^{2}=\mathrm{H}, \mathrm{Cl}, \mathrm{Br}, \mathrm{Me}, \mathrm{OMe}, \mathrm{NO}_{2} ; \mathrm{R}^{3}=\mathrm{OEt}, \mathrm{O} n-\mathrm{Bu}, \mathrm{NEt}_{2} ; \mathrm{R}^{4}=\mathrm{H}, \mathrm{Me}$

$\mathrm{R}^{1}=\mathrm{Me} ; \mathrm{R}^{2}=\mathrm{H} ; \mathrm{R}^{3}=\mathrm{OEt}, \mathrm{R}^{4}=\mathrm{H}: 83 \%^{\mathrm{a}}$

aln the absence of $\mathrm{AcOH}: 62 \%$.

On the basis of their previous studies $[88,89]$, Sigman and co-workers used chiral pyridine oxazoline ligands to perform the enantioselective DHR of indoles with prochiral unsaturated alcohols [90]. Yields and enantioselectivities greatly depended on the substitution of the ligand. Ligands with a naphthyl 
group such as $\mathbf{L}_{1}{ }^{*}$ and $\mathbf{L}_{2}{ }^{*}$ were particularly effective providing aldehydes and ketones in good yields with e.e. up to $92 \%$ (Equation (51)).

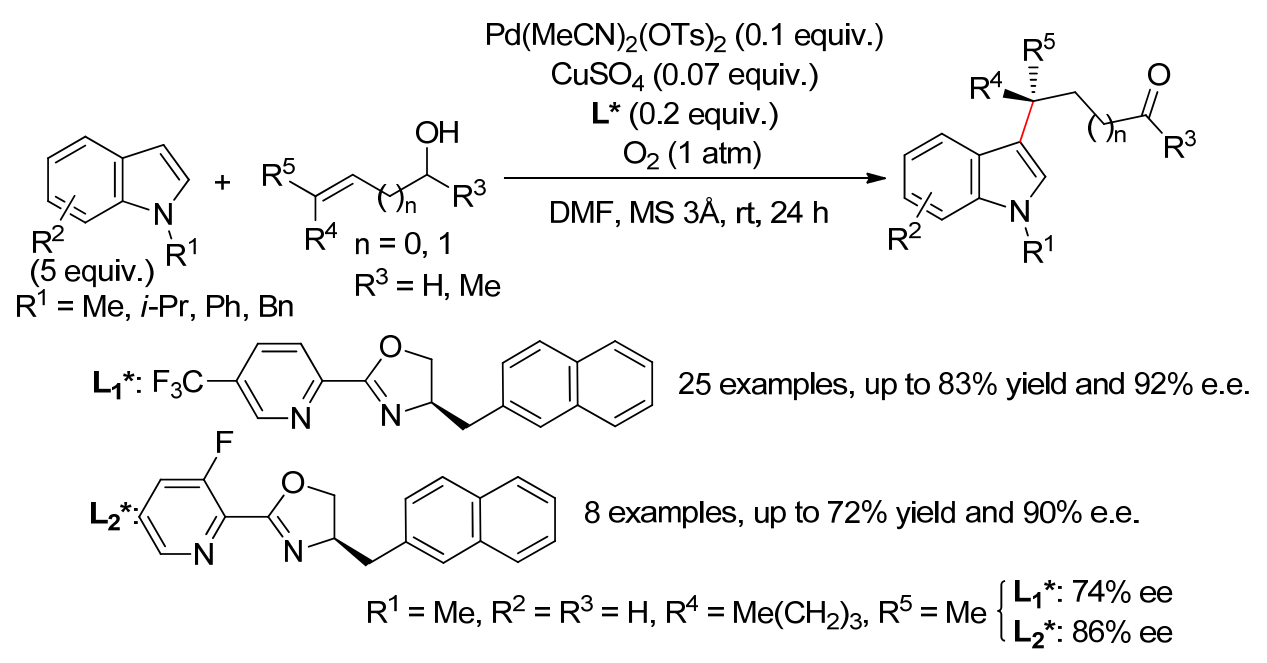

The domino C3 styrenation/annulation with the benzothiophene with an $\mathrm{O}$-methylketoxime group depicted in Chapter 2.2 also occurred with the corresponding indoles (Equation (26)) [59].

Using $\mathrm{Pd}\left(\mathrm{OCOCF}_{3}\right)_{2} / \mathrm{Cu}(\mathrm{OAc})_{2} / \mathrm{H}_{2} \mathrm{O}$ in $\mathrm{DMF} / \mathrm{DMSO}$, enol ethers, and enamides underwent reaction with indoles at their $\alpha$-position to afford the branched adduct, which, under the reaction conditions, led to 3-acylindoles (Equation (52)) [91]. The team of Li and Xiao proposed a mechanism involving alkene activation as depicted in Scheme 1. Nevertheless, a DHR mechanism cannot be discarded, since the Heck reaction of acyclic enol ethers and enamides could also occur at the $\alpha$-position [92-94].

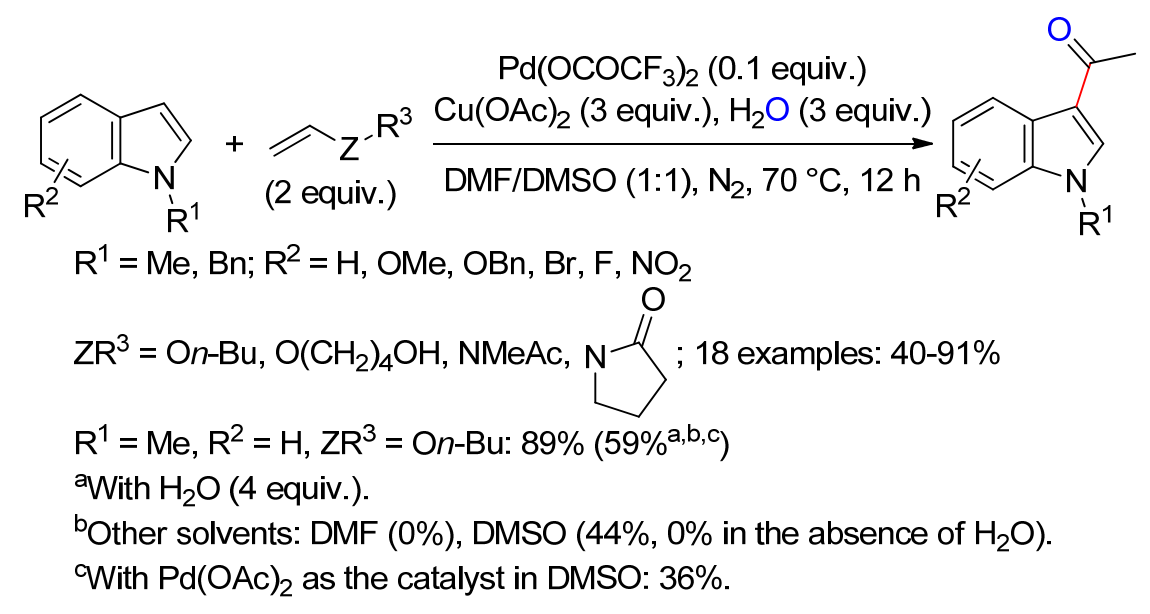

Reaction of $\mathrm{N}$-phenylindole with 3-chloro-1-phenylpropan-1-one provided high yield of the C3 alkenylation, via in situ generation of the enone from the $\beta$-chloro ketone (Equation (53)) [95]. (Under these conditions, $\mathrm{N}$-alkyl, $\mathrm{N}$-benzyl, and $\mathrm{N}$-allylindoles led mainly to annulation products, like those of Equation (61).)

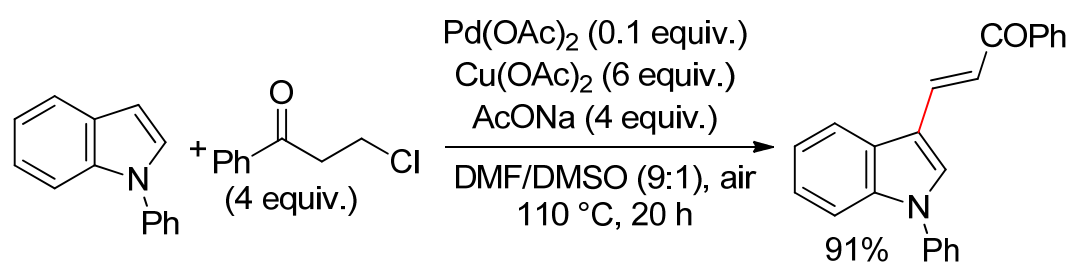




\subsubsection{C2 Alkenylations}

Most reports of selective C2 alkenylations are due to substrates already C3 substituted, as exemplified with Equation (54) [96], Equation (55) [97], Equation (56) [98], and Equation (57) [99].
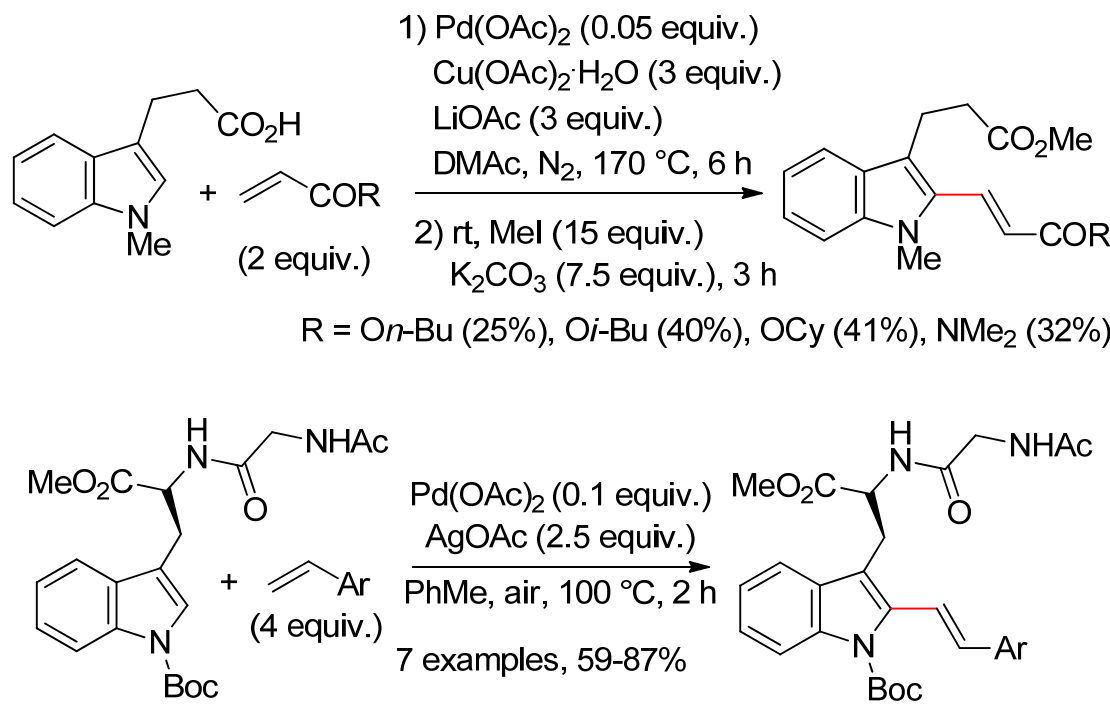

C2 alkenylation may be followed by annulation with the C3 substituent (Equations (56) [98] and (57) [99]). The lactonization depended on the N-substituent of the indole and did not occur with $\mathrm{N}, \mathrm{N}$-dimethylacrylamide as the alkenylating reagent (Equation (56)). The aza-heterocycle (Equation (57)) would be formed as depicted in Scheme 4. Regarding the lactone (Equation (56)), Liu, Zeng, and co-workers proposed the activation of an olefinic $\mathrm{C}-\mathrm{H}$ bond of the DHR product 11A, leading to the seven-membered palladacycle intermediate 11B (Scheme 11). Subsequent reductive elimination gives the lactone. We rather suspect a Wacker-type reaction [100]: activation of the double bond by coordination to $\mathrm{Pd}^{\mathrm{II}}$ mediating the nucleophilic addition leading to 11C. The latter would endure $\beta-\mathrm{H}$ elimination affording the lactone.

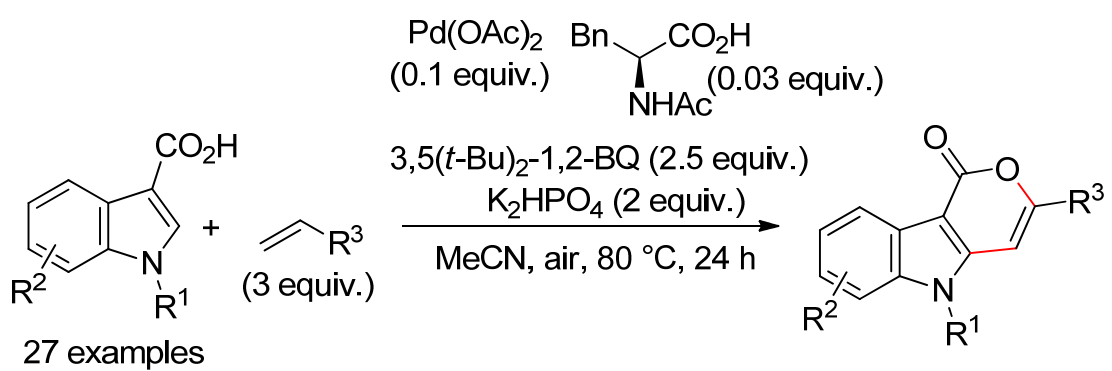

$\mathrm{R}^{1}=\mathrm{Me}, \mathrm{Bn}, i-\mathrm{Pr}, n-\mathrm{Bu}, \mathrm{Ph} ; \mathrm{R}^{2}=\mathrm{H}, \mathrm{Cl}, \mathrm{Br}, \mathrm{F}, \mathrm{Me}, \mathrm{OMe} ; \mathrm{R}^{3}=\mathrm{CO}_{2} \mathrm{R}, \mathrm{Ar}: 51-76 \%$

$\mathrm{R}^{1}=\mathrm{Ts} ; 0 \% . \mathrm{R}^{3}=\mathrm{CONMe}_{2}: 0 \%$.

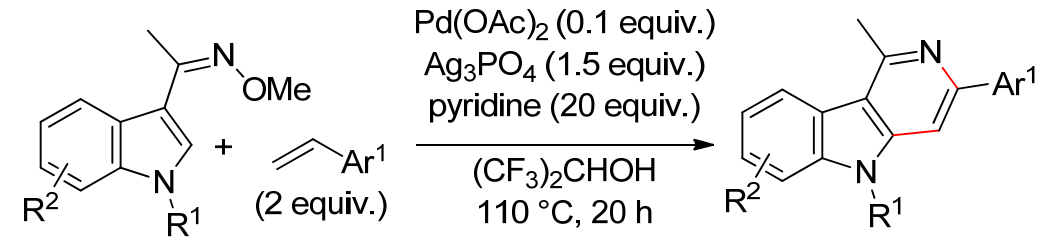

30 examples, 40-83\%; $\mathrm{R}^{1}=\mathrm{Ar}^{2}$, Bn, Me, Et $; \mathrm{R}^{2}=\mathrm{H}, \mathrm{Me}$ 


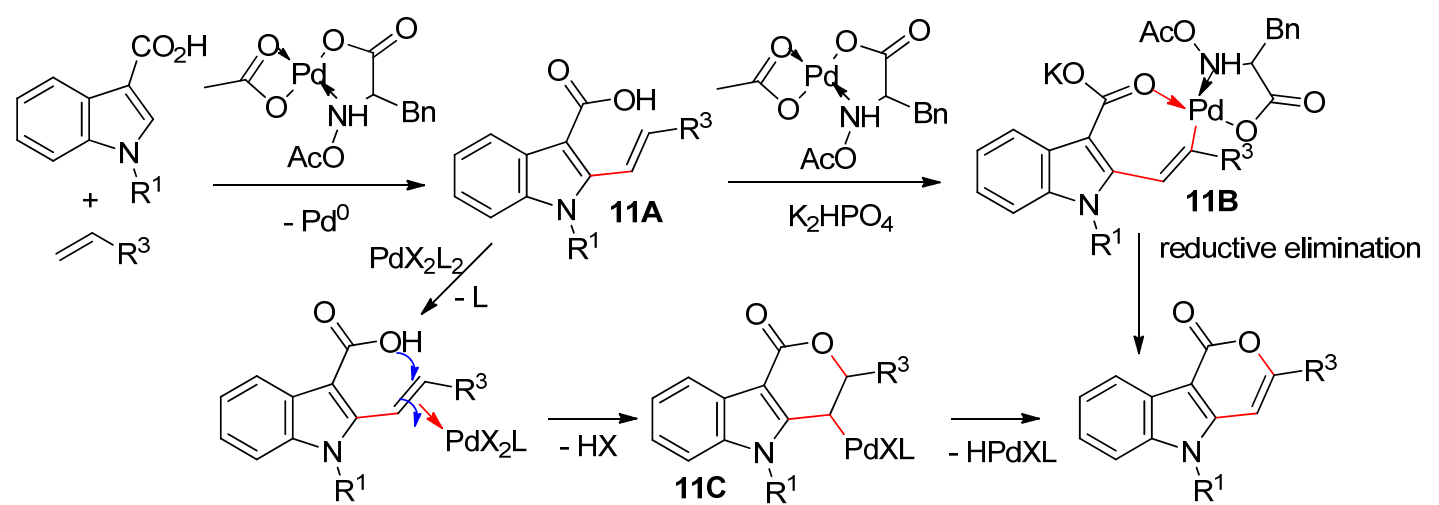

Scheme 11. Plausible pathways of the lactonization.

The $\mathrm{C} 2$ alkenylation/annulation of $N$-(2-(1H-pyrrol-1-yl)phenyl)-4-methylbenzenesulfonamide (Equation (37)) also arose from corresponding indoles (Equation (58)) [74].

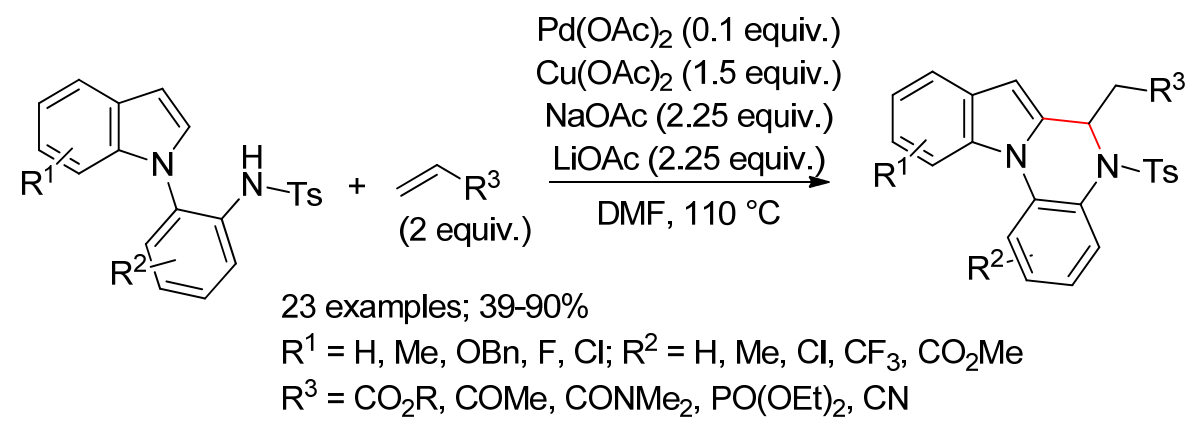

Wang's team effectively carried out various 2-alkenylation of $\mathrm{N}$-(2-pyridyl)sulfonylindoles (Equation (59)) [101]. The cross-coupling with 2,5-dihydrothiophene 1,1-dioxide was followed by migration of the $\mathrm{C}=\mathrm{C}$ bond (Equation (60)). Comparison of the rate of alkenylation of $\mathrm{N}$-(2-pyridyl)sulfonylindoles bearing either a $\mathrm{C} 2$ or $\mathrm{C} 3$ methyl group indicated that the protecting group activates the 2-alkenylation.

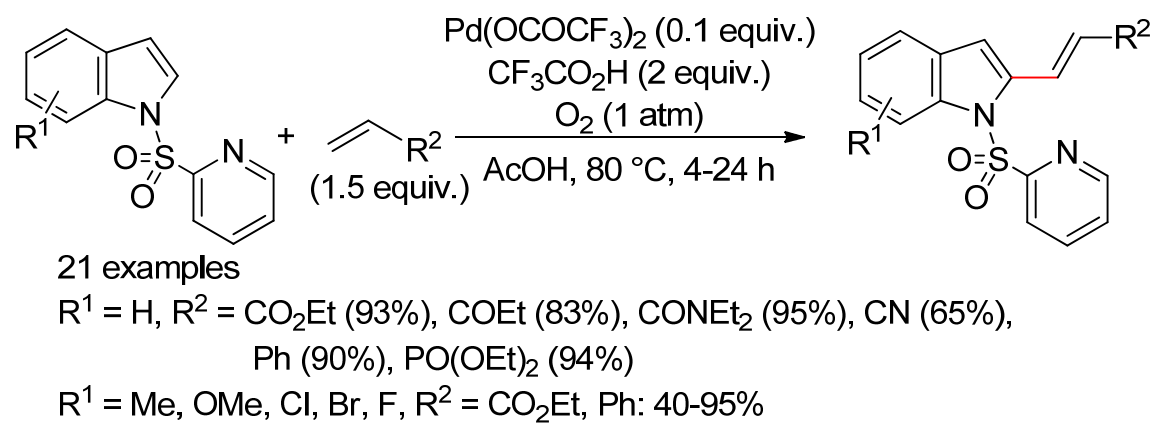

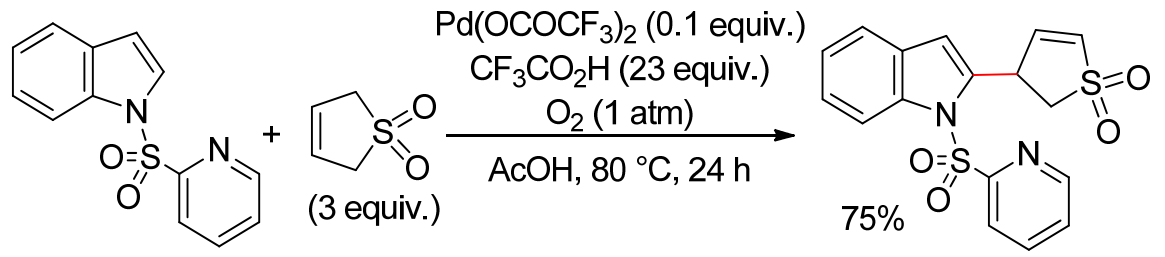

\subsubsection{Domino Reactions}

Domino reactions involving DHRs in 2-position have been above documented (Equations (56)-(58)). 
The annulation depicted in Equation (61) [102] differs from those of Equations (56) and (57). Indeed, the reaction of the exocyclic $\mathrm{C}=\mathrm{C}$ bond with the unsaturated reagent was one of the key intermediates. Plausible intermediates were proposed by Verma's team. According to Scheme 12, the cyclization step is Pd-catalyzed. Similar annulations were reported $[85,95,103]$, but, differing from the DHRs, they will not be more commented.<smiles>[R]C=Cc1c[nH]c2c[R]([H])ccc12</smiles>

18 examples, $54-72 \%$

$\mathrm{R}^{1}=\mathrm{H}, \mathrm{OMe}, \mathrm{Br}, \mathrm{NO}_{2} ; \mathrm{R}^{2}=\mathrm{CO}_{2} \mathrm{R} ; \mathrm{R}^{3}=\mathrm{Ar}, \mathrm{CO}_{2} \mathrm{R}, \mathrm{COMe}$

$\mathrm{R}^{1}=\mathrm{H}, \mathrm{R}^{2}=\mathrm{CO}_{2} \mathrm{Me}, \mathrm{R}^{3}=\mathrm{Ph}, 40 \mathrm{~h}: 70 \%$,

aOther solvents: DMF (25\%), DMSO (trace), DMA (30\%), NMP (0\%).

bWith $\mathrm{Cu}(\mathrm{OAc})_{2}$ (1.8 equiv.), $36 \mathrm{~h}: \mathrm{PdCl}_{2}\left(\mathrm{PPh}_{3}\right)_{2}(60 \%), \mathrm{Pd}(\mathrm{OAc})_{2}(50 \%)$.

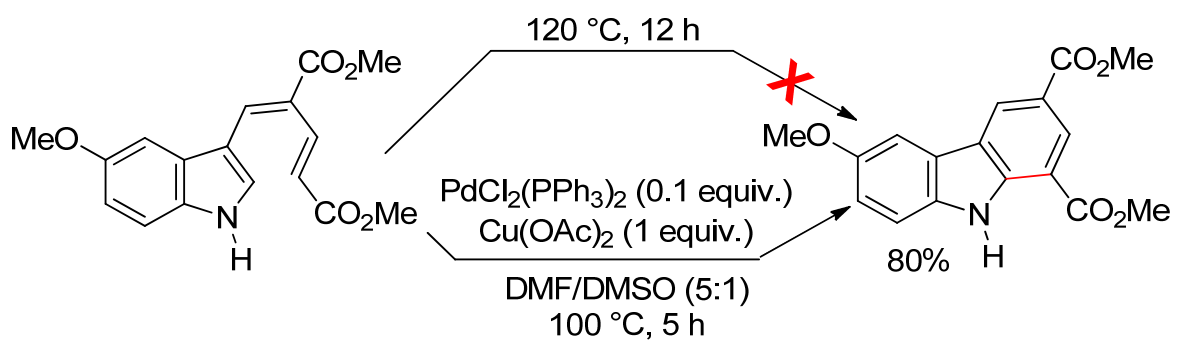

Scheme 12. Cyclization via Pd-catalysis versus thermal conditions.

Increasing the indole/maleimide ratio provided indolopyrrolocarbazoles (Equation (62)) under experimental conditions previously used in Equation (47) [84]. The mechanism proposed by Zhao and co-workers involves the DHR leading to C3 alkenylation product 13A (Scheme 13). Activation of the $\mathrm{C} 2-\mathrm{H}$ bond of $13 \mathrm{~A}$ affords $13 \mathrm{~B}$ which reacts with indole to afford 13C. Subsequent thermal electrocyclization gives the product. In agreement with this proposal, the carbazole was also obtained from the reaction of $\mathrm{C} 3$ alkenylation product with maleimide.

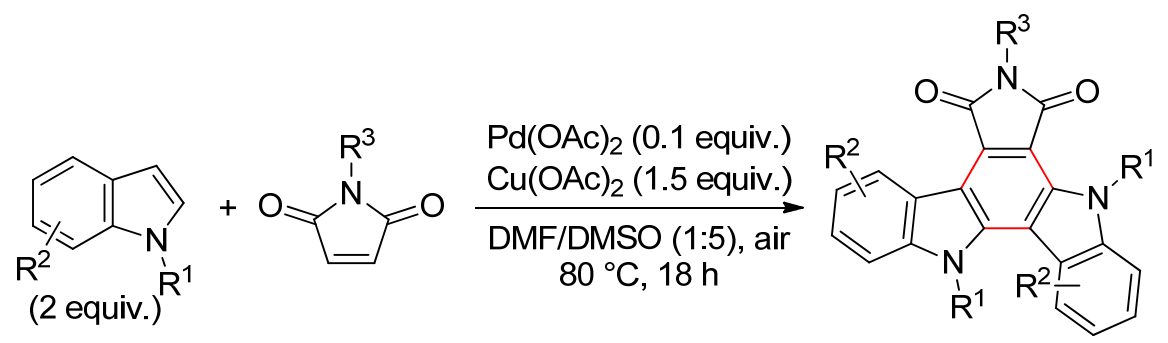

$\mathrm{R}^{1}=\mathrm{H}, \mathrm{Me} ; \mathrm{R}^{2}=\mathrm{H}, \mathrm{Me}, \mathrm{OMe}, \mathrm{OBn} ; \mathrm{R}^{3}=\mathrm{H}, \mathrm{Me}, \mathrm{Ph}$

$\mathrm{R}^{1}=\mathrm{R}^{2}=\mathrm{R}^{3}=\mathrm{H}: 75 \%$ a,b

11 examples, $55-85 \%$

aOther solvents: DMF (34\%), DMSO (56\%), dioxane (trace).

bOther oxidants in DMSO: $\mathrm{Ag}_{2} \mathrm{CO}_{3}(17 \%), \mathrm{AgNO}_{3}(15 \%), \mathrm{DDQ}(0 \%), \mathrm{O}_{2}(0 \%)$. 


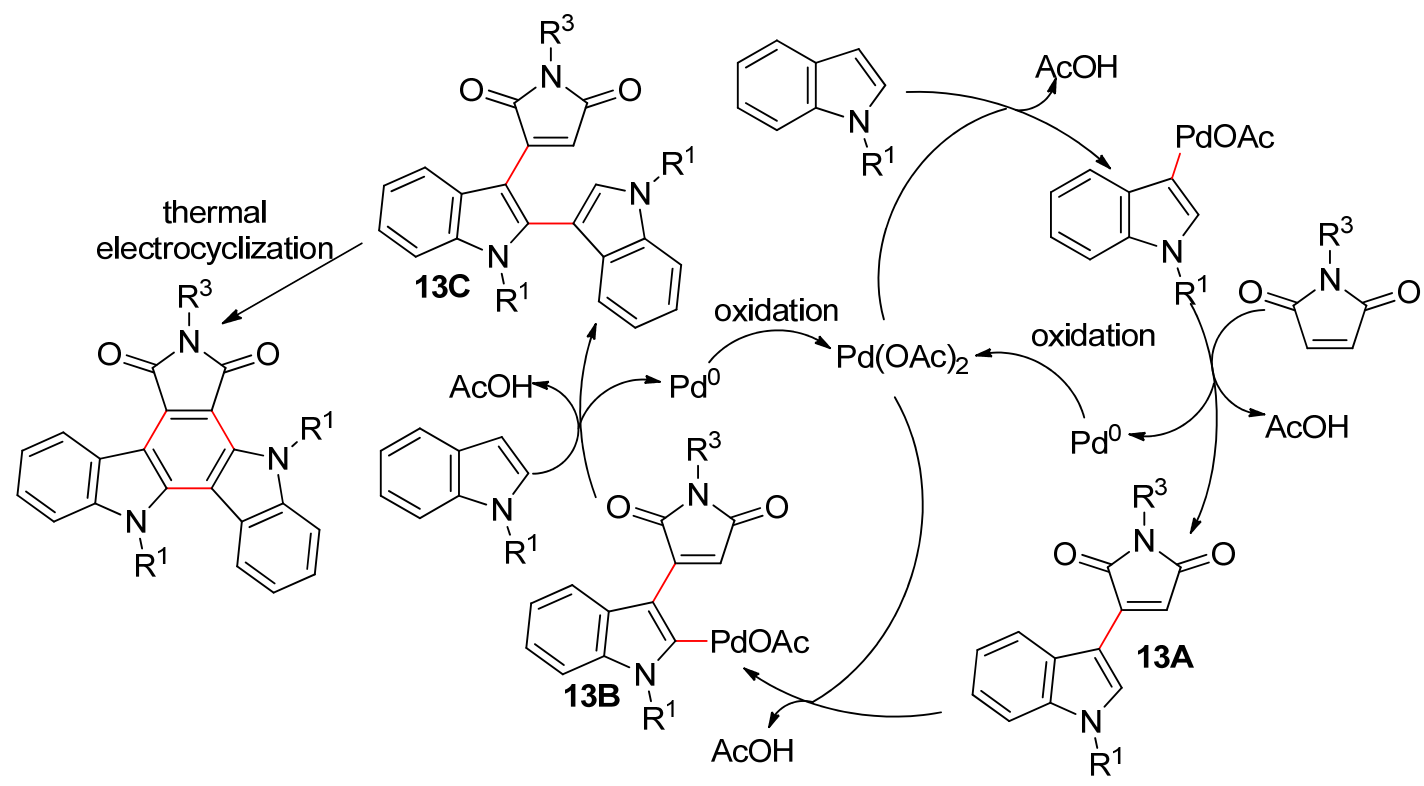

Scheme 13. Domino reaction of maleimide with indole.

The cross-coupling of $N$-methyl and $N$-benzylindoles with methyl acrylate afforded a mixture of two isomeric carbazoles (Scheme 14, path a) [104]. The process became selective with others $\mathrm{N}$-substituents, (path $b$ ) arising from a double DHR reaction followed, according Equation (63), thermal electrocyclization. The annulation was not observed from free $(\mathrm{NH})$ indole (path $c$ ).<smiles>COC(=O)/C=C/c1c(/C=C/C(C)=O)c2ccccc2n1Cc1ccccc1</smiles><smiles>COc1cc2c(cc1C)c1ccccc1n2Cc1ccccc1</smiles>

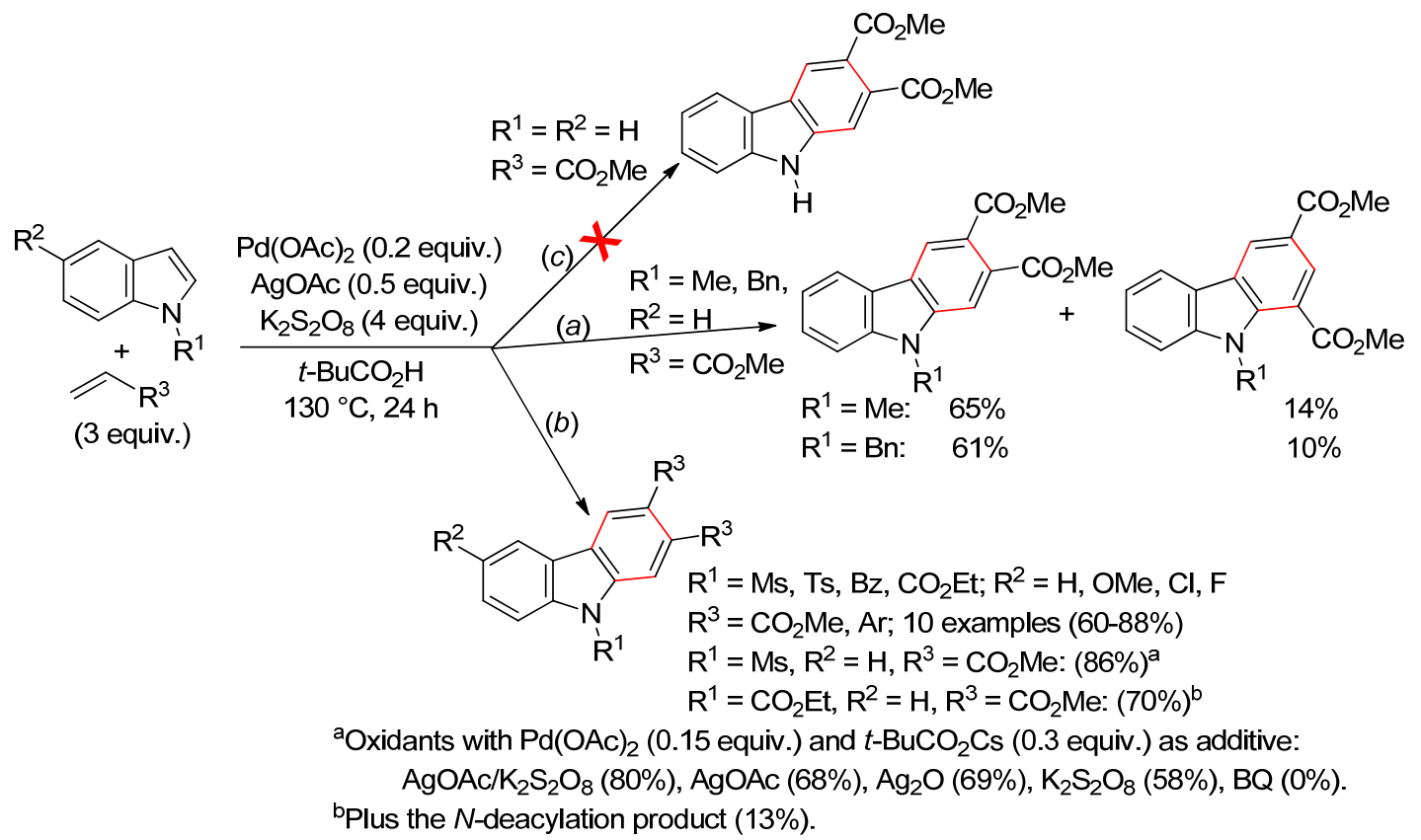

Scheme 14. Reactivity depending on the N substituent. 


\subsection{7-Azaindoles}

7-Azaindoles underwent aerobic C-3 alkenylation at room temperature using catalytic amounts of $\mathrm{Pd}(\mathrm{OAc})_{2}, \mathrm{PPh}_{3}$, and $\mathrm{Cu}(\mathrm{OTf})_{2}$ (Equation (64)) [105]. The yields were very sensitive to the solvent and oxidant.

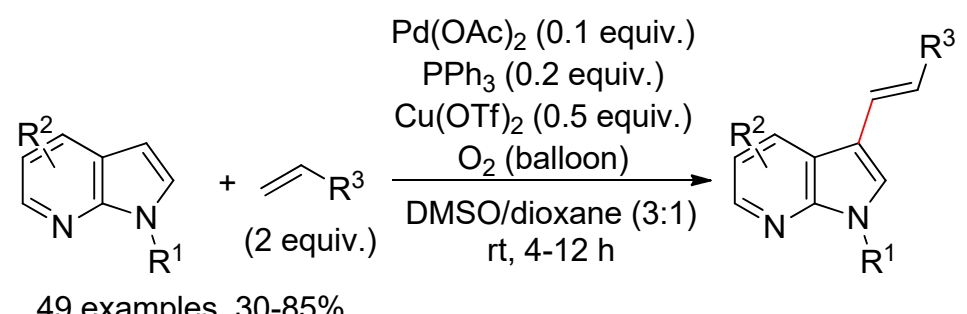

49 examples, $30-85 \%$

$\mathrm{R}^{1}=\mathrm{PMB}, \mathrm{Bn}, \mathrm{Ph} ; \mathrm{R}^{2}=\mathrm{H}, \mathrm{Cl}, \mathrm{Br}, \mathrm{Ar}, \mathrm{OMe} ; \mathrm{R}^{3}=\mathrm{CO}_{2} \mathrm{R}, \mathrm{CN}, \mathrm{Ar}$

$\mathrm{R}^{1}=\mathrm{PMB}, \mathrm{R}^{2}=\mathrm{H}, \mathrm{R}^{3}=\mathrm{CO}_{2} n-\mathrm{Bu}: 80 \%^{\mathrm{a}}$

aOther oxidants: $\mathrm{O}_{2}, \mathrm{BQ}, \mathrm{Phl}(\mathrm{OAc})_{2}, \mathrm{~K}_{2} \mathrm{~S}_{2} \mathrm{O}_{8}(10-20 \%)$.

\subsection{Indolizines}

The DHR of indolizines preferentially occurred at the 3-position (Equations (65) and (66) [27] and Equation (67) [106]. When the 3-position was already occupied, the cross-coupling arose in C1 position (Equation (68)) [107].

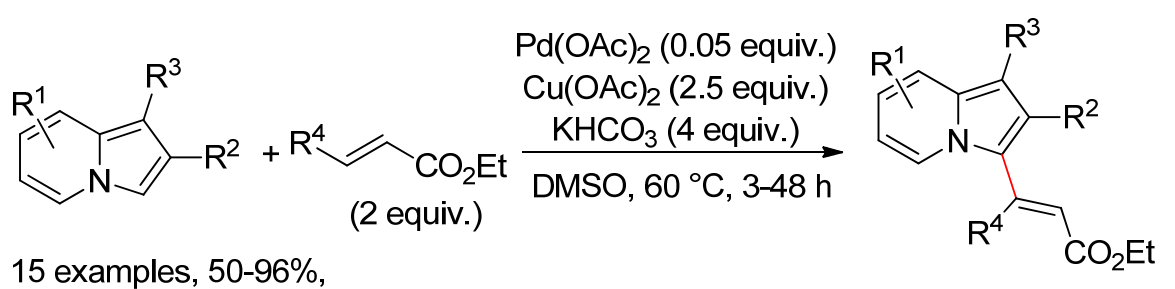

$\mathrm{R}^{1}=\mathrm{H}, \mathrm{Me} ; \mathrm{R}^{2}=\mathrm{H}, \mathrm{CO}_{2} \mathrm{R}, \mathrm{Me}, \mathrm{Ar} ; \mathrm{R}^{3}=\mathrm{H}, \mathrm{CN}, \mathrm{CO}_{2} \mathrm{R}, \mathrm{CONMe}_{2}, \mathrm{COPh} ; \mathrm{R}^{4}=\mathrm{H}, \mathrm{Me}$

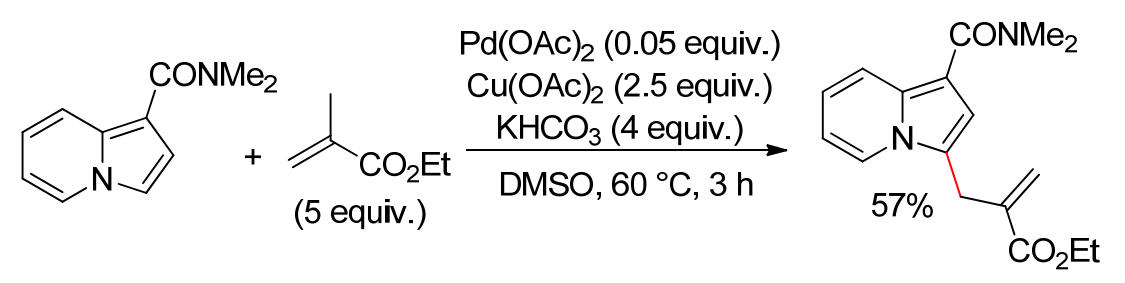

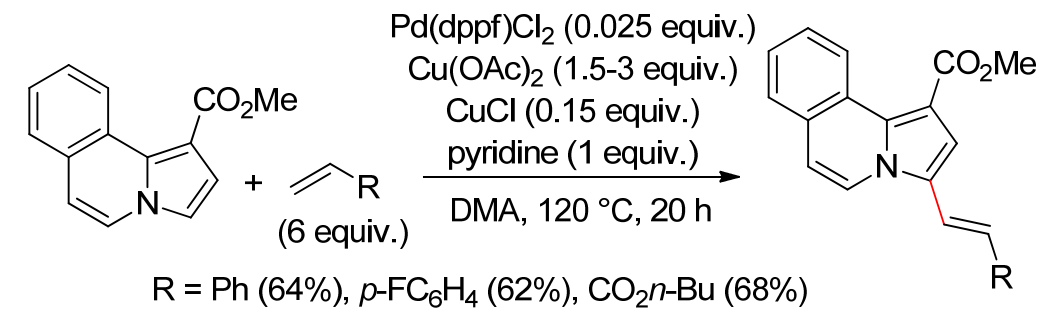




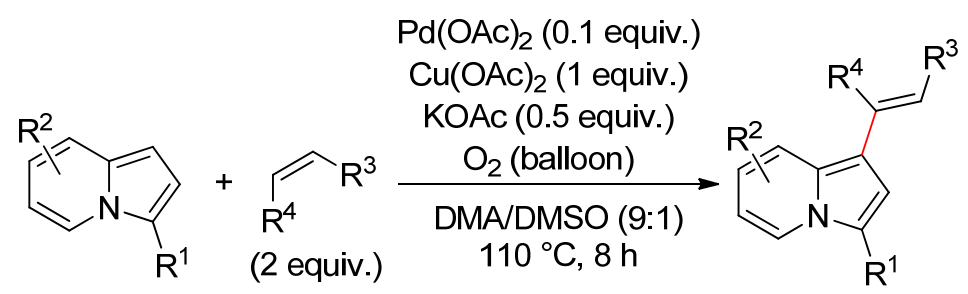

26 examples, $42-95 \%$

$\mathrm{R}^{1}=\mathrm{COAr}, \mathrm{CO}_{2} \mathrm{R}, \mathrm{Ph} ; \mathrm{R}^{2}=\mathrm{H}, \mathrm{CO}_{2} \mathrm{R} ; \mathrm{R}^{3}=\mathrm{CO}_{2} \mathrm{R}, \mathrm{CONMe}_{2}, \mathrm{PO}(\mathrm{OMe})_{2}, \mathrm{Ar}$;

$\mathrm{R}^{4}=\mathrm{H}, \mathrm{CO}_{2} \mathrm{Me}, p-\mathrm{MeC}_{6} \mathrm{H}_{4}(\mathrm{E} / \mathrm{Z}=1.3: 1)$

$\mathrm{R}^{1}=\mathrm{COPh}, \mathrm{R}^{2}=\mathrm{R}^{4}=\mathrm{H}, \mathrm{R}^{3}=\mathrm{CO}_{2} \mathrm{Bu} ; 88 \%{ }^{\mathrm{a}}$

${ }^{a}$ In the absence of $\mathrm{Cu}(\mathrm{OAc})_{2}: 79 \%$.

Using $\mathrm{PdCl}_{2} / \mathrm{K}_{2} \mathrm{CrO}_{4} / \mathrm{H}_{2} \mathrm{O} / \mathrm{O}_{2}$ in DMF, C1-substituted indolizines underwent cross-coupling with $\alpha, \beta$-unsaturated carboxylic acids to produce C3 acylated compounds (Equation (69)) [108]. Traces of annulation products were identified; they were selectively formed under modified experimental conditions (Equation (70)). According to Zhang and co-workers, the first steps of the acylation are those of the DHR leading to 15A (Scheme 15). Oxidation of the activated tertiary hydrogen bond of 15A with $\mathrm{K}_{2} \mathrm{CrO}_{4}$ provides 15B. Subsequent hydrolysis of the C-Pd bond affords $15 \mathrm{C}$ that is oxidized with $\mathrm{K}_{2} \mathrm{CrO}_{4}$ giving the acylated compound. The annulation product would arise from $15 \mathrm{~A}$ via $\beta-\mathrm{H}$ elimination leading to $15 \mathrm{D}$. Subsequent oxidation with $\mathrm{BQ} / \mathrm{K}_{2} \mathrm{CrO}_{4}$ affords $15 \mathrm{E}$. Activation of $\mathrm{C}-\mathrm{H}$ bond in 5 position gives the palladacycle 15F, which delivers the product via reductive elimination and decarboxylation.
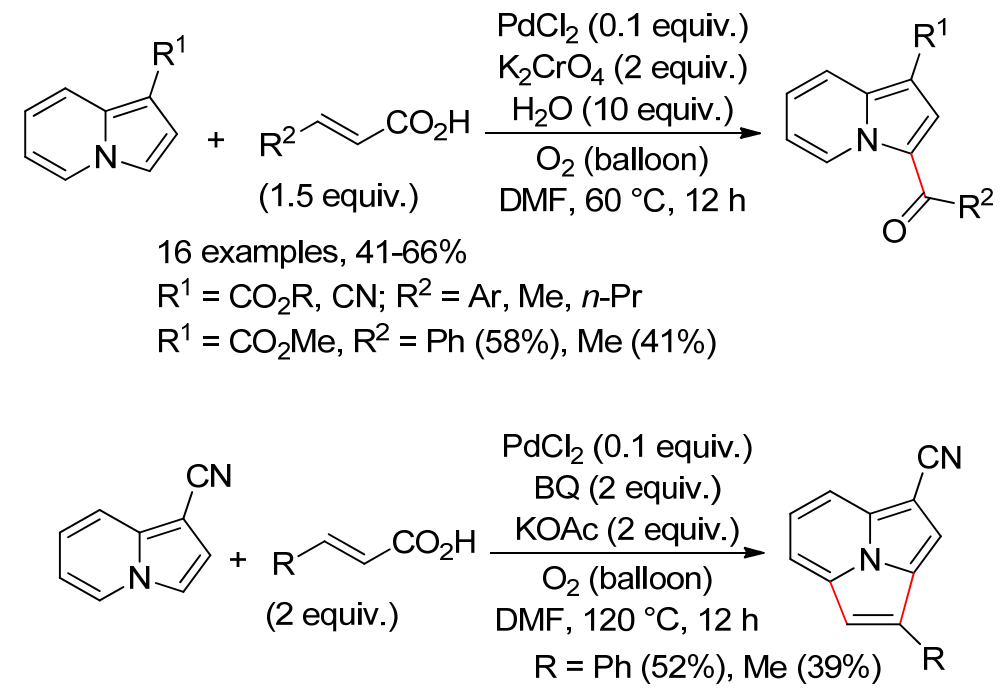

\subsection{Sub-Conclusion}

The regioselectivity of the DHR of pyrroles depends on solvent, $\mathrm{N}$ protective group, and, if present, electron-withdrawing substituents. Indoles react in 3 position in the absence of directing substituent.

Under DHR conditions, the C3 position of 7-azaindoles and indolizines is the more reactive. It seems however necessary to note that the $\mathrm{C} 3$ position relative to the $\mathrm{N}$ atom is $\beta$ for the former and $\alpha$ for the latter. 
<smiles>[R]C(=O)c1cc([R])c2ccccn12</smiles>

Scheme 15. DHRs with $\alpha, \beta$-unsaturated carboxylic acids: acylation versus annulation.

\section{Se-Arenes}

Although Fujiwara's team disclosed, in 1973, the synthesis of 2-styrylselenophene and 2,5-distyrylselenophene from stoichiometric amounts of selenophene, styrene, and $\operatorname{Pd}(\mathrm{OAc})_{2}$ in refluxing $\mathrm{AcOH} /$ dioxane [29], the DHRs of Se-arenes under catalytic conditions have been seldom reported.

\subsection{Selenophenes}

$\mathrm{Pd}(\mathrm{OAc})_{2}$-catalyzed DHR of selenophenes with $\mathrm{Ag}_{2} \mathrm{CO}_{3}$ as oxidant in the presence of $t-\mathrm{BuCO}_{2} \mathrm{H}$ provided the $\alpha$-mono or $\alpha, \alpha^{\prime}$-diolefination products depending on the olefinating agent/selenophene ratio (Equations (71) and (72)) [109].

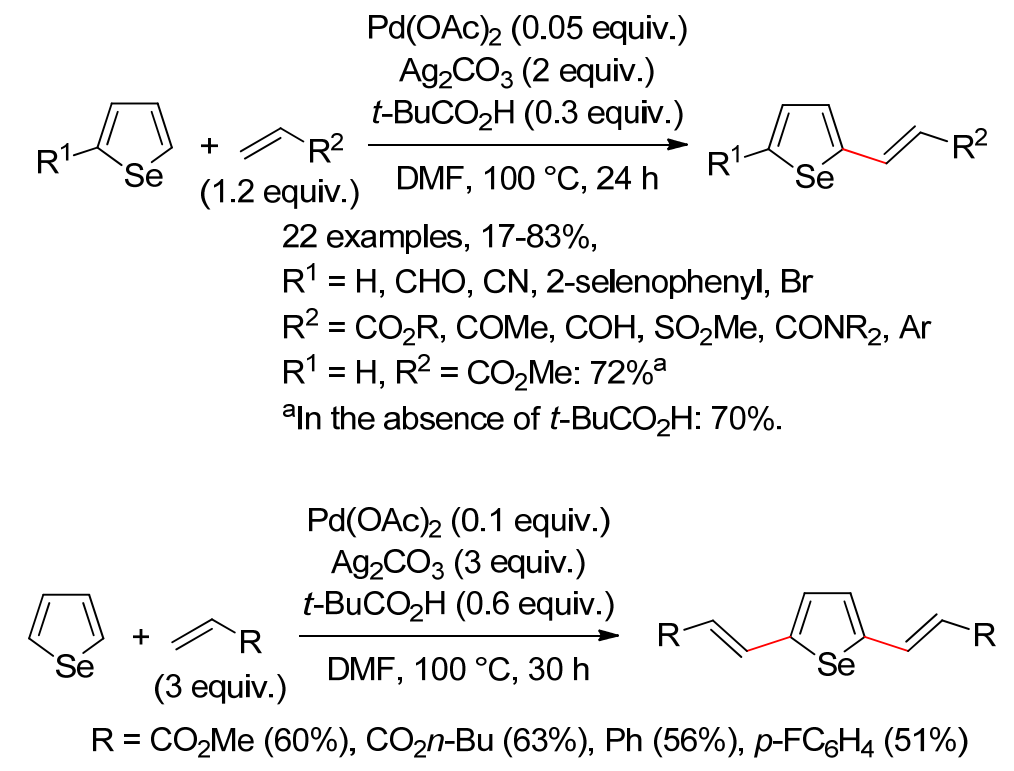




\subsection{Benzoselenophene}

Benzoselenophene reacted under conditions of selenophene to yield the $\mathrm{C} 2$ substituted product (Equation (73)) [109].

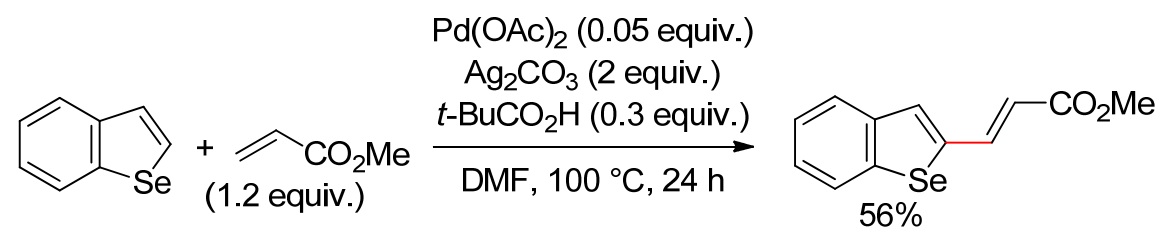

\section{S,N-Arenes}

\subsection{Thiazoles}

Homocoupling competed with DHR from thiazoles substituted in 2 and 5 positions (Equation (74)) [110].

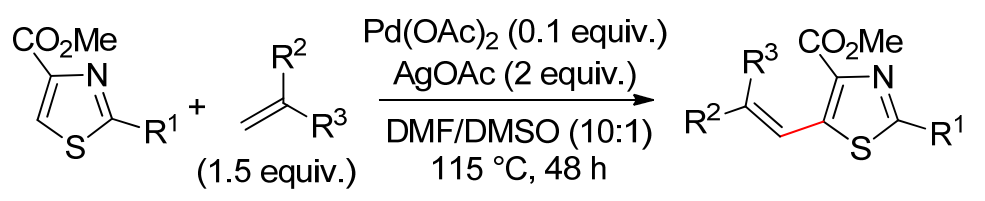

21 examples, $46-82 \%$

$\mathrm{R}^{1}=\mathrm{Ar}, \mathrm{CH}_{2} \mathrm{Bn}, n-\mathrm{Pr}, \mathrm{Bz} ; \mathrm{R}^{2}=\mathrm{CO}_{2} \mathrm{R}, \mathrm{Ph} ; \mathrm{R}^{3}=\mathrm{H}, \mathrm{Me}$

$\mathrm{R}^{1}=\mathrm{Bz}, \mathrm{R}^{2}=\mathrm{CO}_{2} n-\mathrm{Bu}, \mathrm{R}^{3}=\mathrm{H}: 61 \%^{\mathrm{a}}$

aplus $\mathrm{MeO}_{2} \mathrm{C}$

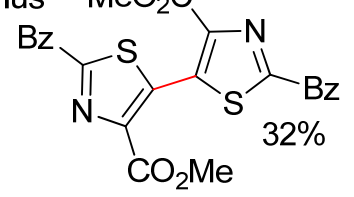

Unsubstituted thiazole and thiazoles substituted in 4 or/and 5 position underwent $C-2$ selective olefination using $\mathrm{Pd}(\mathrm{OAc})_{2} / 1,10$-phenanthroline/ $\mathrm{AgNO}_{3}$ in $\mathrm{DMSO}$ (Equation (75)) [111]. The presence of 1,10-phenanthroline was essential for this DHR.

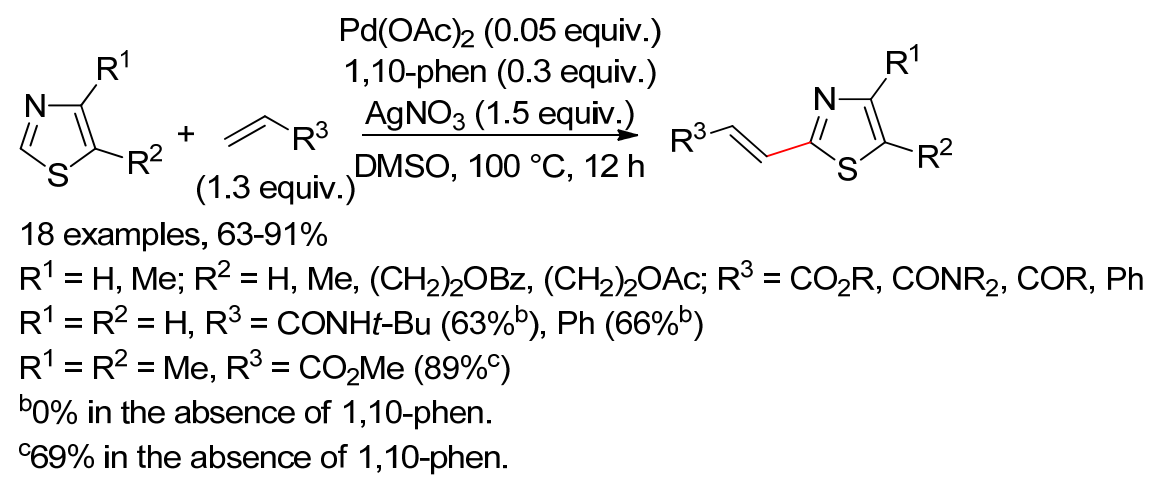

Maiti's team studied the olefination of 4-methylthiazole [112]. With $\mathrm{Pd}(\mathrm{OAc})_{2} / \mathrm{AgOAc}$ in trifluoroethanol containing catalytic amounts of $\mathrm{N}$-acetylglycine, the reaction with methyl acrylate led to a complex mixture (Equation (76)). The authors examined the DHR in the presence of tricoordinating templates to direct the metal catalyst to the desired $\mathrm{C} 5-\mathrm{H}$ bond. They founded an effective recyclable 
template for the purpose (Equation (76)). Interestingly, selective C5-olefination also occurred from 4-chlorothiazole, 2-methylthiazole, and unsubstituted thiazole (Equation (77)).

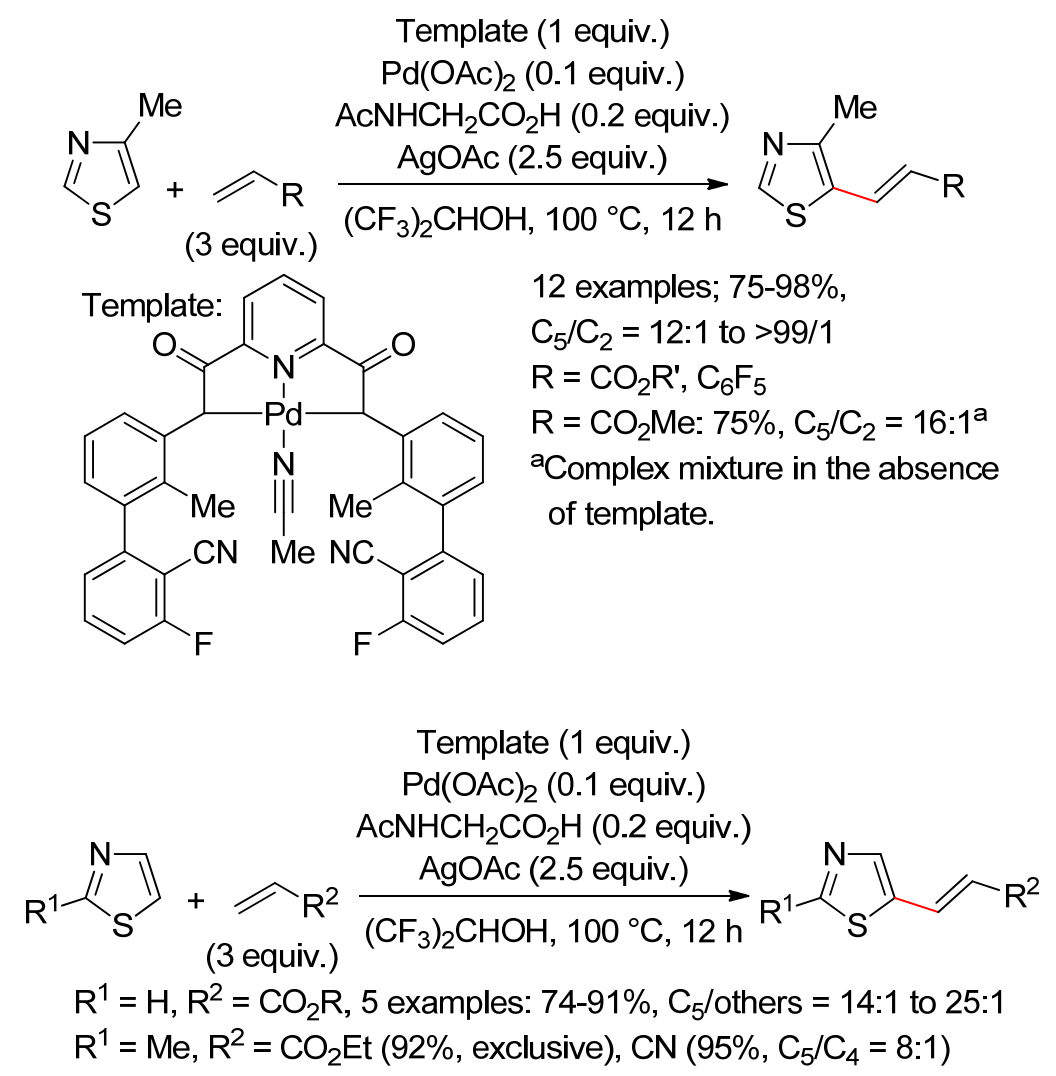

The key intermediates proposed by Maiti's team for the template reactions are depicted in Scheme 16 [112]. Exchange between acetonitrile and thiazole provides 16A. Activation of C5-H bond due to interaction with the aromatic nitrile allowed regioselective palladation leading to $16 \mathrm{~B}$, while the $\mathrm{C} 2-\mathrm{H}$ bond is preserved. Subsequent reaction with the olefin gives $\mathbf{1 6 C}$, which liberates the product and regenerates the template.

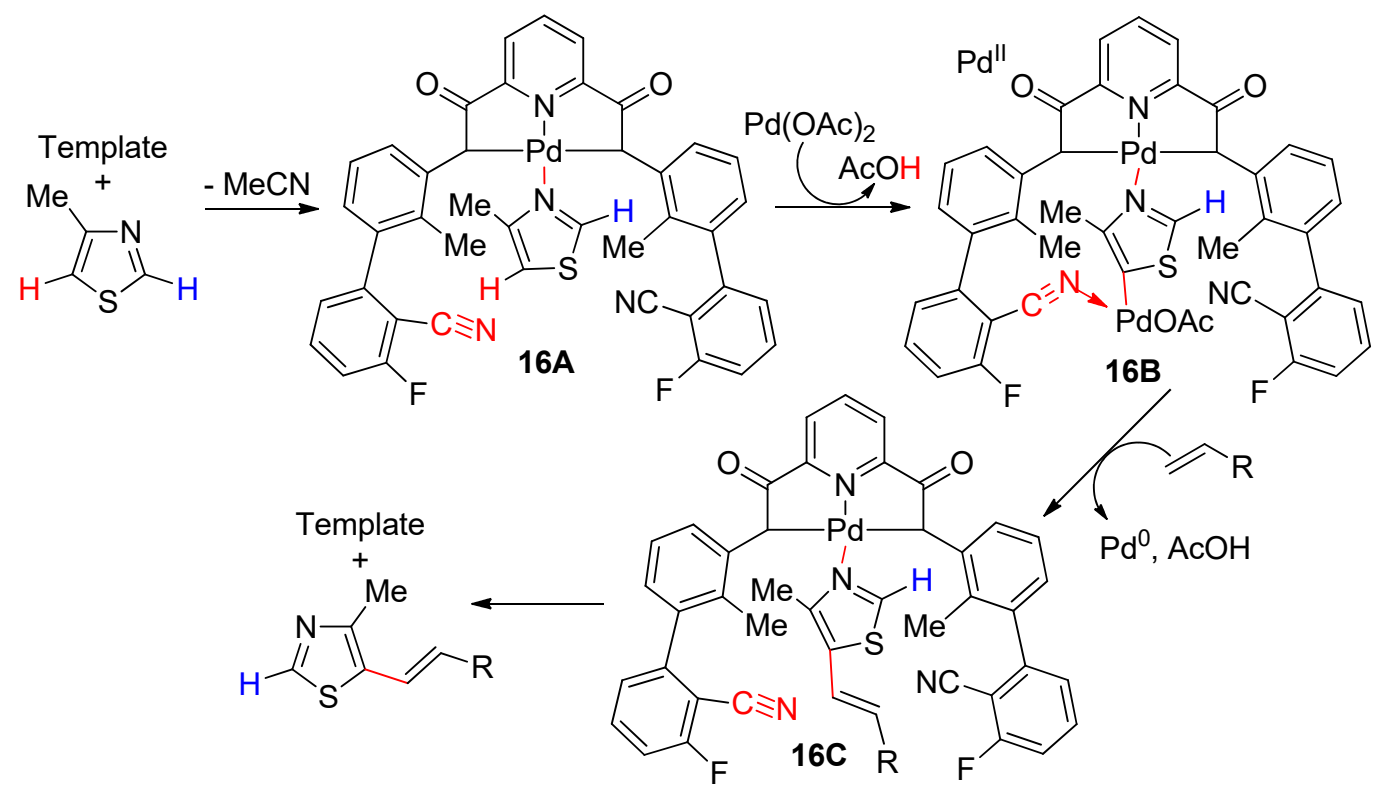

Scheme 16. Template-mediated regioselectivity. 


\subsection{Isothiazoles}

The DHR of 3-methyl-5-phenylisothiazole with butyl acrylate using $\mathrm{Pd}(\mathrm{OAc})_{2} / \mathrm{Cu}(\mathrm{OAc})_{2}$ in DMA was sluggish at $120^{\circ} \mathrm{C}$, giving the product in a low yield (Equation (78)) [113].

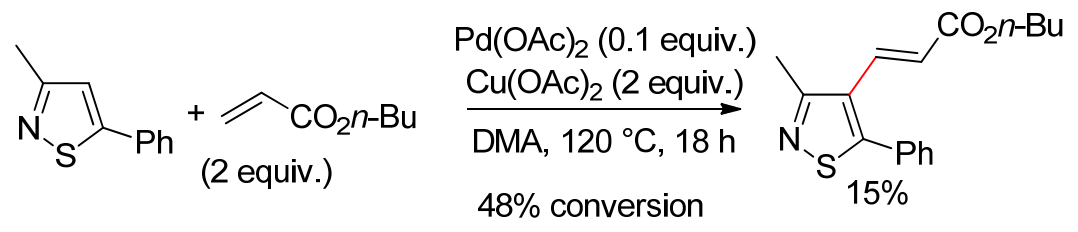

\subsection{Benzothiazoles}

The Pd(OAc) 2 /1,10-phenanthroline association (Equation (75)) also led to efficient C2 substitution of benzothiazole with acrylates, $N$-methylacrylamide (Scheme 17) [111], and styrene (Equation (79)) [114]. Lower yield was obtained with 1-octene (Scheme 17). Moreover, the formation of the branched cross-coupling product led us to suspect a mechanism involving activation of the alkene (Scheme 1). Indeed, the Heck reaction of terminal alkenes preferentially occurs at the terminal carbon $[115,116]$, while nucleophilic addition to Pd-coordinated alkenes arises rather at the internal carbon [117-119].
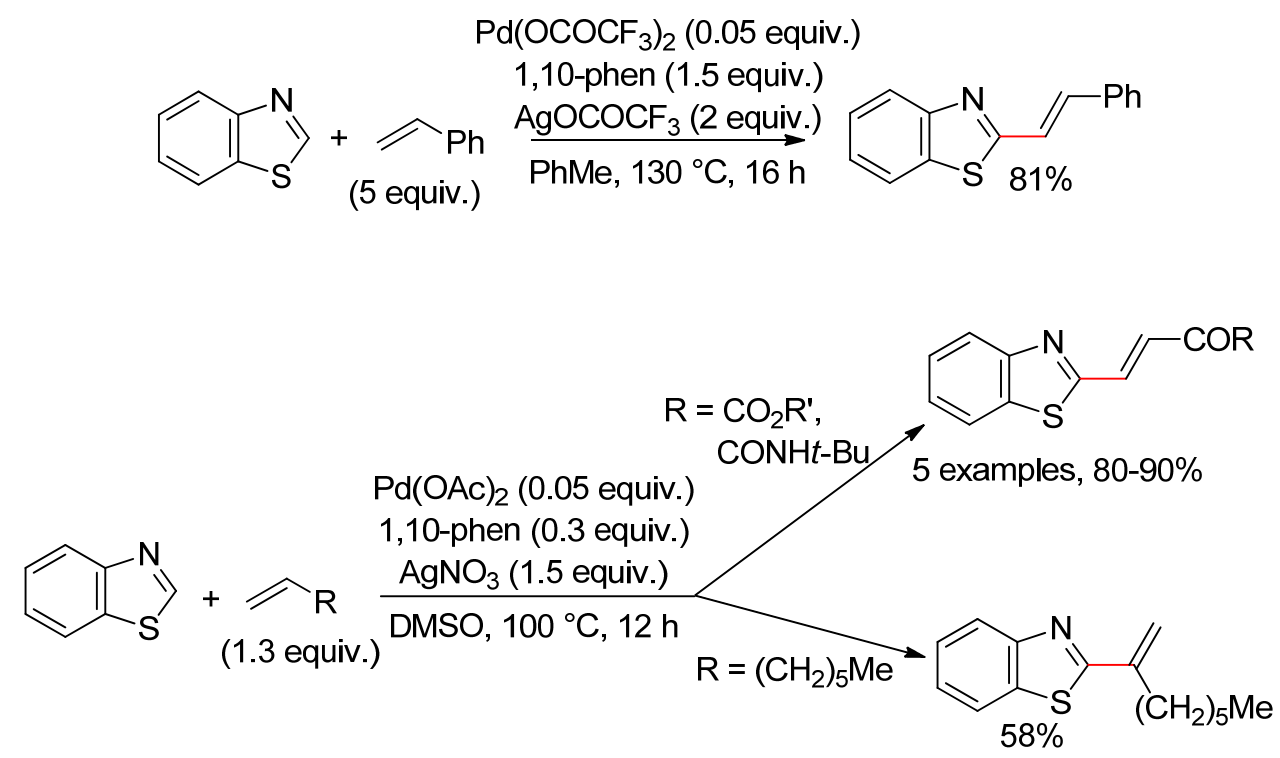

Scheme 17. Linear and branched cross-coupling products.

\subsection{Thiazolotriazoles}

Both $\mathrm{Cu}(\mathrm{OAc})_{2}$ and $\mathrm{O}_{2}$ as the oxidation sytem and dioxane as the solvent were used as optimum conditions for the $\mathrm{Pd}(\mathrm{OAc})_{2}$-catalyzed $\mathrm{DHR}$ of 6-substituted thiazolo[3,2-b]-1,2,4-triazoles, leading to 
selective 5-alkenylation (Equation (80)) [120]. It seems necessary to point out the absence of reaction at the 2-position.

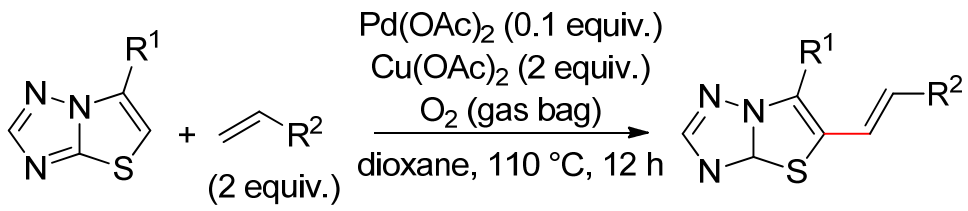

13 examples; $\mathrm{R}^{1}=\mathrm{Me}, \mathrm{Ph} ; \mathrm{R}^{2}=\mathrm{CO}_{2} \mathrm{R}, \mathrm{CONHR}, \mathrm{CO}_{2} \mathrm{H}, \mathrm{Ar}: 33-85 \%$

$\mathrm{R}^{1}=\mathrm{Me} ; \mathrm{R}^{2}=\mathrm{CO}_{2} n-\mathrm{Bu}: 82 \%$, b

aOther oxidants: $\mathrm{Cu}(\mathrm{OAc})_{2}(72 \%), \mathrm{O}_{2}(17 \%), \mathrm{BQ}(23 \%)$,

$$
\mathrm{Ag}_{2} \mathrm{CO}_{3}(41 \%), \mathrm{K}_{2} \mathrm{~S}_{2} \mathrm{O}_{8}(11 \%) \text {. }
$$

bOther solvents: DMF (72\%), DMSO (53\%), AcOH (76\%), MeCN (35\%).

\subsection{Imidazo[2,1-b]thiazoles}

3-Substituted imidazo[2,1-b]thiazoles bearing an aryl group in C6 underwent selective 2-alkenylation (Equation (81)), while change of the aryl group for a methyl led to 2,5-disubstitution (Equation (82)) [121]. According to Huang, Chen, and co-workers, electronic effects played a more important role than steric effects in the reaction.

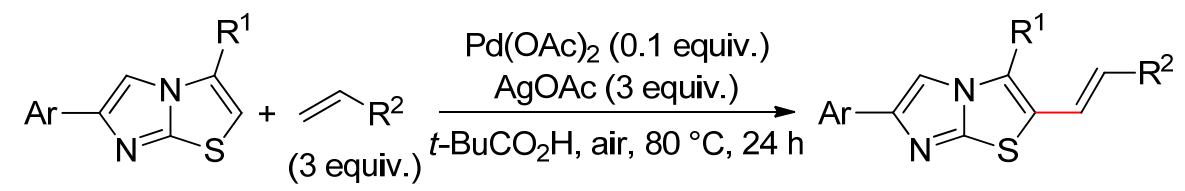

18 examples, $65-91 \%$

$\mathrm{R}^{1}=\mathrm{Me}, i-\mathrm{Pr}, i-\mathrm{Bu}, n-\mathrm{Bu} ; \mathrm{R}^{2}=\mathrm{CO}_{2} \mathrm{R}, \mathrm{CONMe}_{2}, \mathrm{CN}, \mathrm{PO}(\mathrm{OEt})_{2}, \mathrm{Ar}$

$\mathrm{Ar}=\mathrm{Ph}, \mathrm{R}^{1}=\mathrm{Me}, \mathrm{R}^{2}=\mathrm{CO}_{2} t-\mathrm{Bu}: 89 \%^{\mathrm{a}}$

aOther solvents: DMF, dioxane, DMA, $\mathrm{AcOH}, \mathrm{CF}_{3} \mathrm{CO}_{2} \mathrm{H}$ : 0\%-trace.

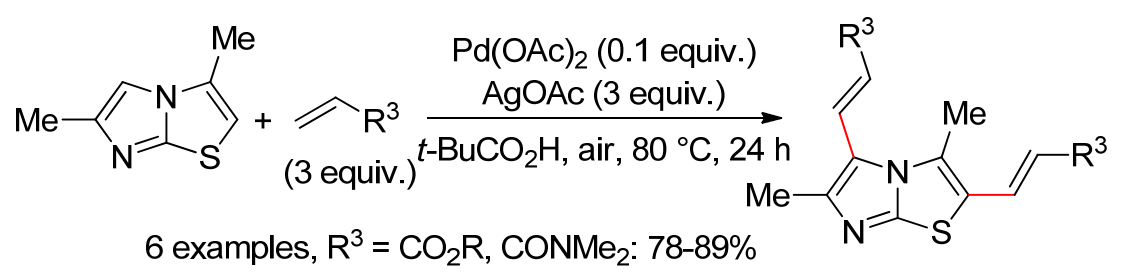

\section{O,N-Arenes}

\subsection{Oxazoles}

Olefination of disubstituted oxazoles in either the 4- (Equation (83)) [122] or 2-position (Equation (84)) [114], depending on the substitution of the starting material, have been reported. $\mathrm{Pd}(\mathrm{OAc})_{2}$-catalyzed DHR of 5-methoxy-2-(4-methoxyphenyl)oxazole with $n$-butyl acrylate occurred in high yield in $\mathrm{MeCN}$ with $\mathrm{Cu}(\mathrm{OAc})_{2}$ as oxidant, but changing the oxidant or the solvent provided 
only traces of the cross-coupling product, especially in DMF/DMSO which is often used for DHR of five-membered heteroarenes (Equation (83)).

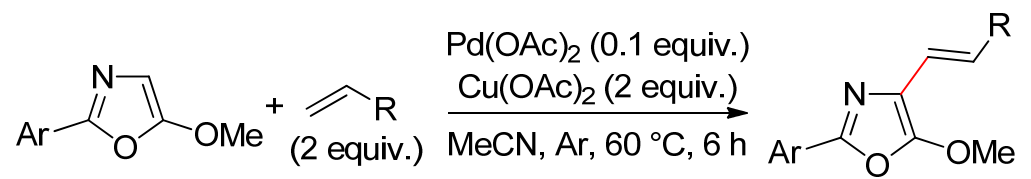

15 examples, $26-87 \%$

$\mathrm{Ar}=p-\mathrm{MeOC}_{6} \mathrm{H}_{4}, \mathrm{O}-\mathrm{MeOC}_{6} \mathrm{H}_{4}$

$\mathrm{R}=\mathrm{CO}_{2} \mathrm{R}^{\prime}, \mathrm{COMe}, \mathrm{CONPhEt}, \mathrm{Ar}, \mathrm{TMS}, \mathrm{CH}=\mathrm{CHPh}$

$\mathrm{Ar}=p-\mathrm{MeOC}_{6} \mathrm{H}_{4}, \mathrm{R}=\mathrm{CO}_{2} n-\mathrm{Bu}\left(84 \%{ }^{\mathrm{a}, \mathrm{b}}\right), \mathrm{COMe}(52 \%), \mathrm{Ph}(73 \%)$

aOther oxidants: AgOAc (<5\%), BQ ( $0 \%)$.

bOther solvents: DMSO (<5\%), DMF/DMSO (<5\%), AcOH (0\%).

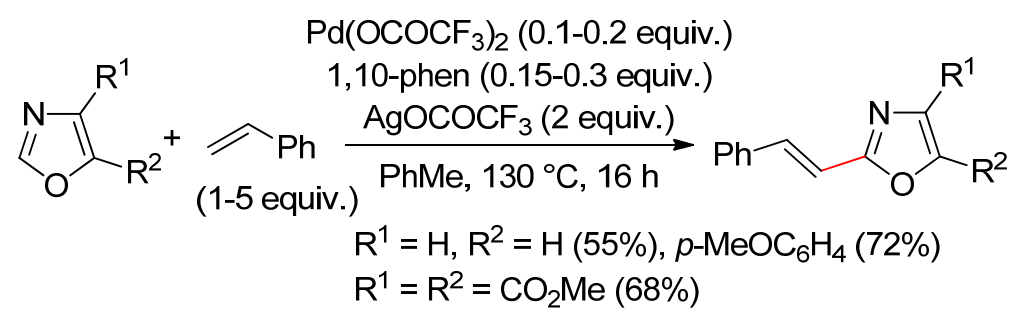

\subsection{Oxazolones}

4-Alkenylation of 5-substituted-2-oxazolones mediated with the $\mathrm{Pd}(\mathrm{OAc})_{2} / \mathrm{Cu}(\mathrm{OAc})_{2}$ system was very sensitive to the experimental conditions (Equation (85)) [123]. Unconjugated compounds, formed via $\beta-\mathrm{H}$ elimination involving the methyl group, were the main cross-coupling products from $\alpha$-methylstyrene and methyl methacrylate (Equation (86)).
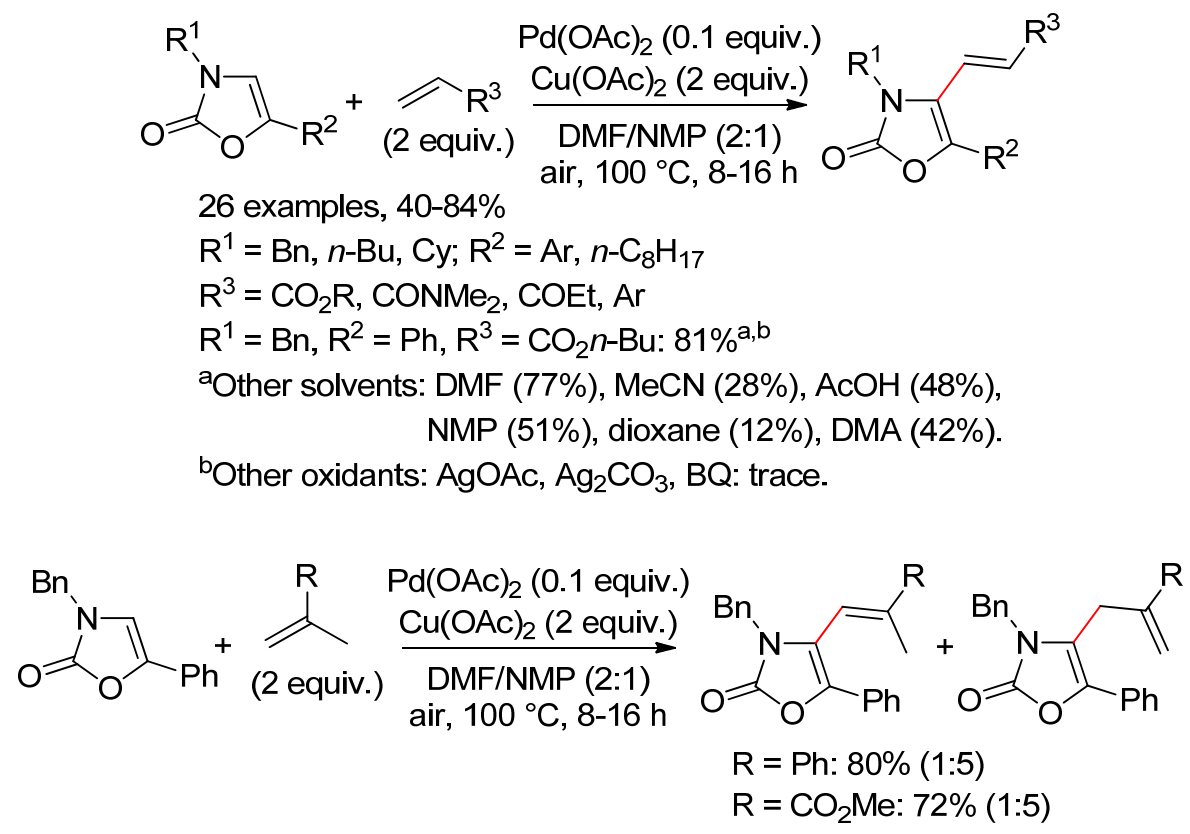


\subsection{Isoxazoles}

The $\mathrm{Pd}(\mathrm{OAc})_{2} / \mathrm{Cu}(\mathrm{OAc})_{2} / \mathrm{DMA}$ association which has a low efficiency for the DHR of isothiazole (Equation (78)) afforded fair yields from isoxazoles (Equation (87)) [113].

$$
\begin{aligned}
& 6 \text { examples, 55-68\% } \\
& \mathrm{R}^{1}=\mathrm{Me}, \mathrm{Ph} ; \mathrm{R}^{2}=\mathrm{CO}_{2} n-\mathrm{Bu}, \mathrm{CO}_{2} t-\mathrm{Bu}, \mathrm{CONMe}_{2}, \mathrm{Ph} \\
& \mathrm{R}^{1}=\mathrm{Me}, \mathrm{R}^{2}=\mathrm{CO}_{2} n-\mathrm{Bu} 63 \% ; \mathrm{R}^{1}=\mathrm{Ph} ; \mathrm{R}^{2}=\mathrm{CONMe}_{2}: 58 \%
\end{aligned}
$$

\subsection{Benzoxazoles}

1,10-Phenanthroline would be the optimum ligand of $\mathrm{Pd}\left(\mathrm{OCOCF}_{3}\right)_{2}$ for the 2-alkenylation of benzoxazoles (Equation (88)) [114].

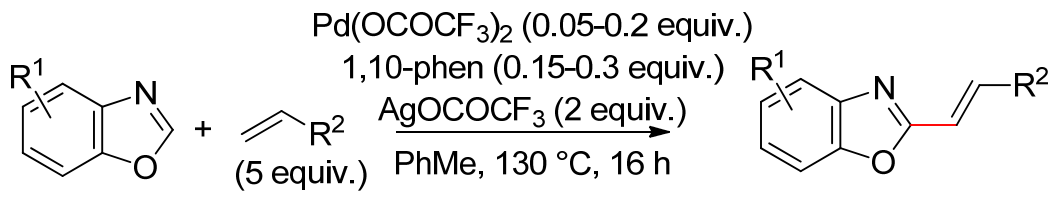

$$
\begin{aligned}
& 24 \text { examples, 32-94\% } \\
& \mathrm{R}^{1}=\mathrm{H}, \mathrm{Me}, \mathrm{Cl}, \mathrm{Ph}, \mathrm{CO}_{2} \mathrm{Me} ; \mathrm{R}^{2}=\mathrm{Ar}, \mathrm{CO}_{2} \mathrm{R} \\
& \mathrm{R}^{1}=\mathrm{H}, \mathrm{R}^{2}=\mathrm{Ph}: 87 \% \%^{\mathrm{a}, \mathrm{b}} \\
& \text { aln the absence of 1,10-phen: } 60 \% \text {. } \\
& \text { bOther ligands: } \mathrm{PCy}_{3}(50 \%) \text {, bipyridine (50\%). }
\end{aligned}
$$

\section{8. $\mathbf{N}, \mathrm{N}$-Arenes}

\subsection{Pyrazoles}

The 4-alkenylation of $\mathrm{N}$-methylpyrazole and 3,5-dimethyl- $\mathrm{N}$-methylpyrazole using $\mathrm{Pd}(\mathrm{OAc})_{2} / \mathrm{Cu}(\mathrm{OAc})_{2} / \mathrm{DMA}$ occurred in low yields (Equation (89)) [113]. $\mathrm{N}$-phenylpyrazole was unreactive [113], but could react under different conditions (see Equation (91)).

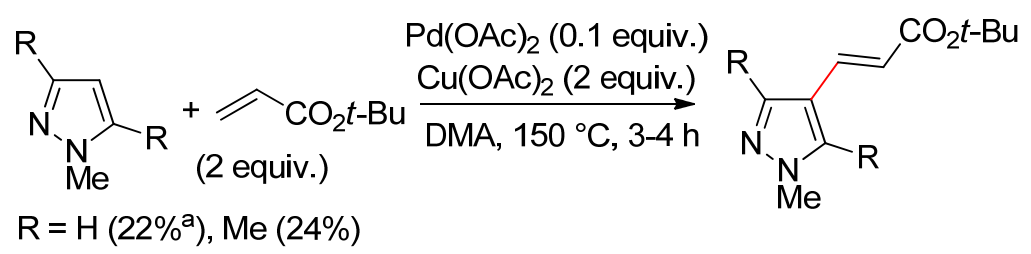

aplus $30 \%$ yield of a $4: 1$ mixture of 4,5- and 3,4-dialkenylated products.

The DHR of 5-aryl-3-(trifluoromethyl)- $1 \mathrm{H}$-pyrazoles using $\mathrm{Pd}(\mathrm{OAc})_{2} / \mathrm{Ag}_{2} \mathrm{CO}_{3}$ in DMF required an excess of the pyrazole to afford fair to good yields (Equation (90)) [124]. These conditions were 
not effective for the DHR of 3-(difluoromethyl)-5-aryl-1H-pyrazoles: addition of BQ was required (Equation (91)).

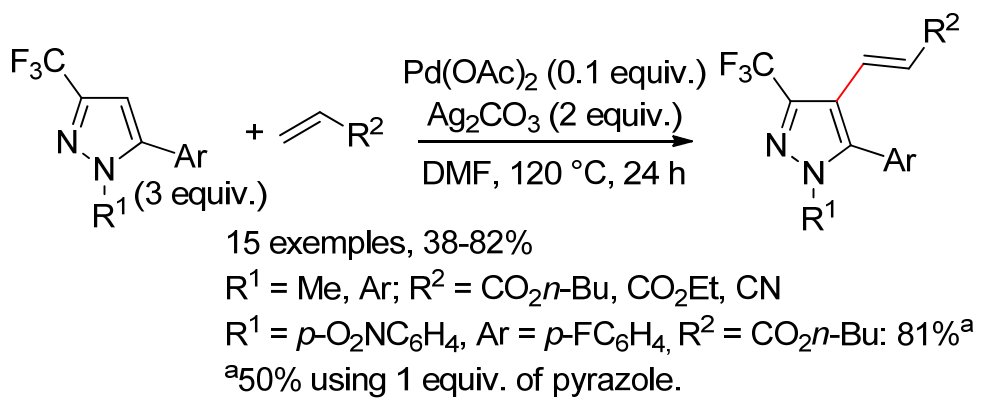

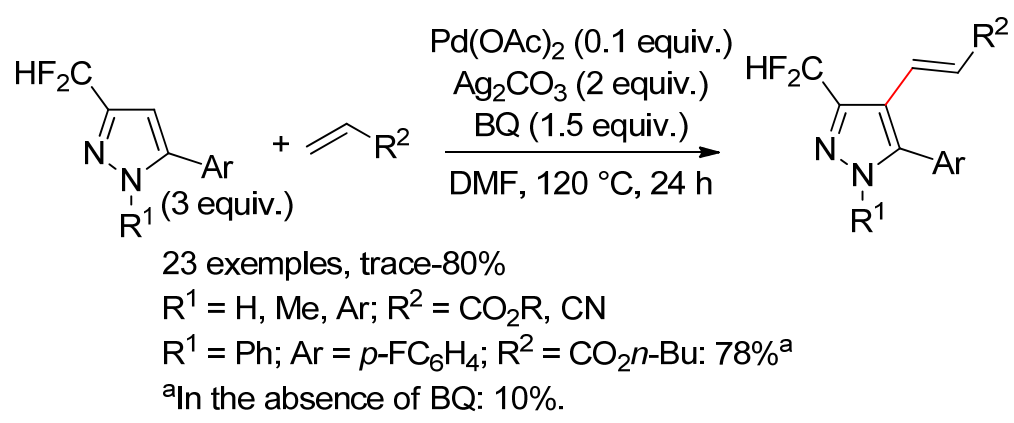

4-Substituted pyrazoles underwent $\mathrm{C} 5$ alkenylation using $\mathrm{Pd}(\mathrm{OAc})_{2} / \mathrm{Cu}(\mathrm{OAc})_{2}$ in dioxane, in increased yields with pyridine as additive (Equation (92)) [125].

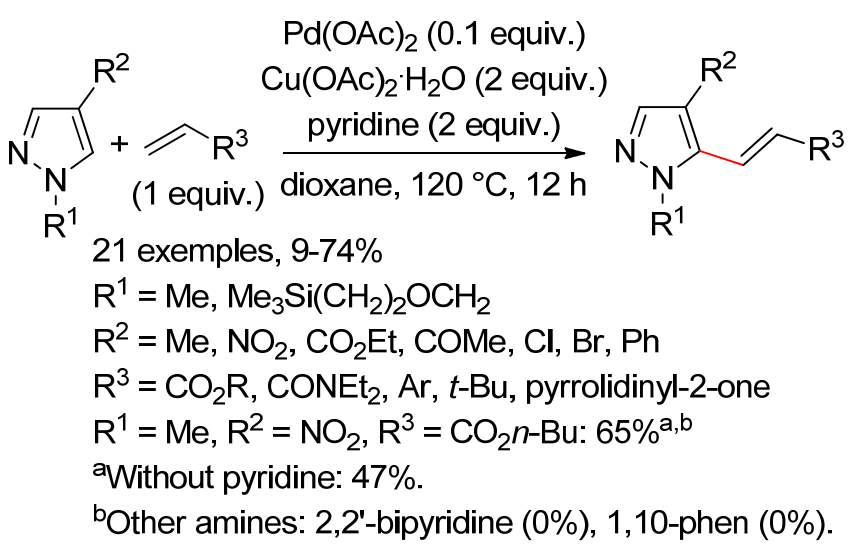

The teams of Lim, Baik, and Joo joined their efforts to selectively obtain either C4 or C5 alkenylation of 1-methyl-1H-pyrazole, via a ligand-controlled regiodivergent process (Scheme 18) [126]. Besides the ligand, the experiment conditions also differed. The two methods were applied to 
different $\mathrm{N}$-substituted pyrazoles, possibly C3-substituted. A third method was optimized for the 4,5-dialkenylation (Equation (93)).
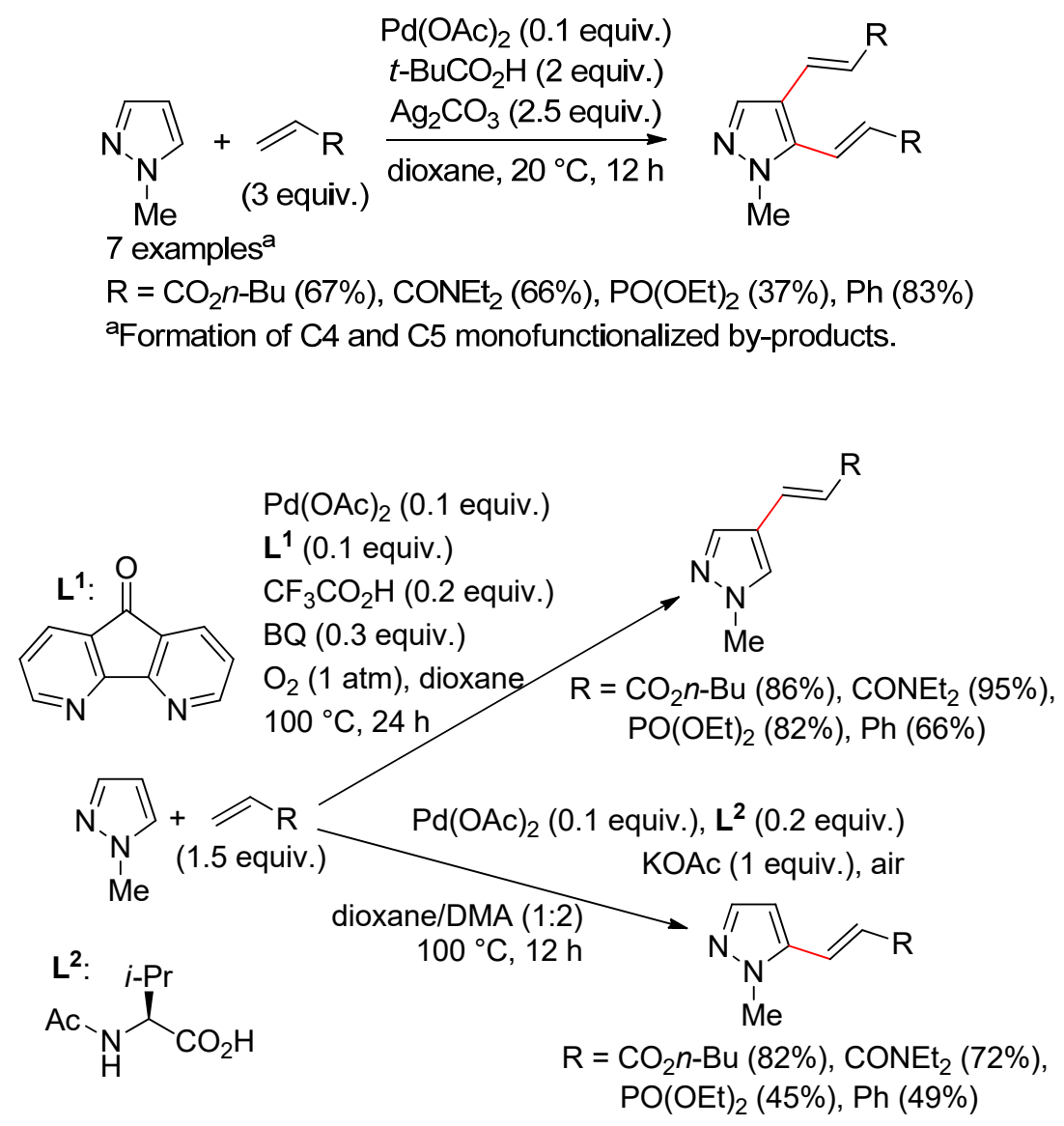

Scheme 18. Lim, Baik, and Joo's divergent DHR's.

\subsection{Pyrazolones}

Substituted 5-pyrazolones led to various 4-alkenylated pyrazolones via DHRs sensitive to the nature of oxidant and solvent (Equation (94)) [127].

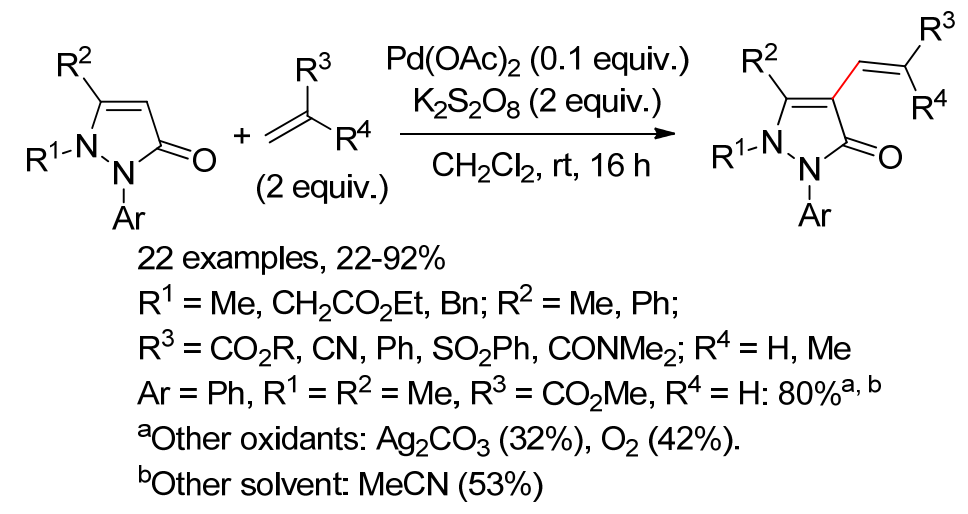

\subsection{Indazoles}

Guillaumet's team disclosed the $\mathrm{Pd}^{\mathrm{II}}$-catalyzed C3-alkenylation of 2-methyl-2H-indazoles (Equation (95)) and 1-methyl-1H-indazoles (Equation (96)) using $\mathrm{Ag}_{2} \mathrm{CO}_{3}$ as oxidant and stoichiometric amounts of both $\mathrm{AcOH}$ and $\mathrm{Ac}_{2} \mathrm{O}$ for optimum yields [128]. The DHR arose in $\mathrm{C} 7$ from C3-substituted substrates. The same substrates were subsequently C3-alkenylated with butyl acrylate 
and $N, N$-diethylacrylamide (42-72\% yields) by Joo's team under experimental conditions they used for pyrazoles (Equation (92)) [125].
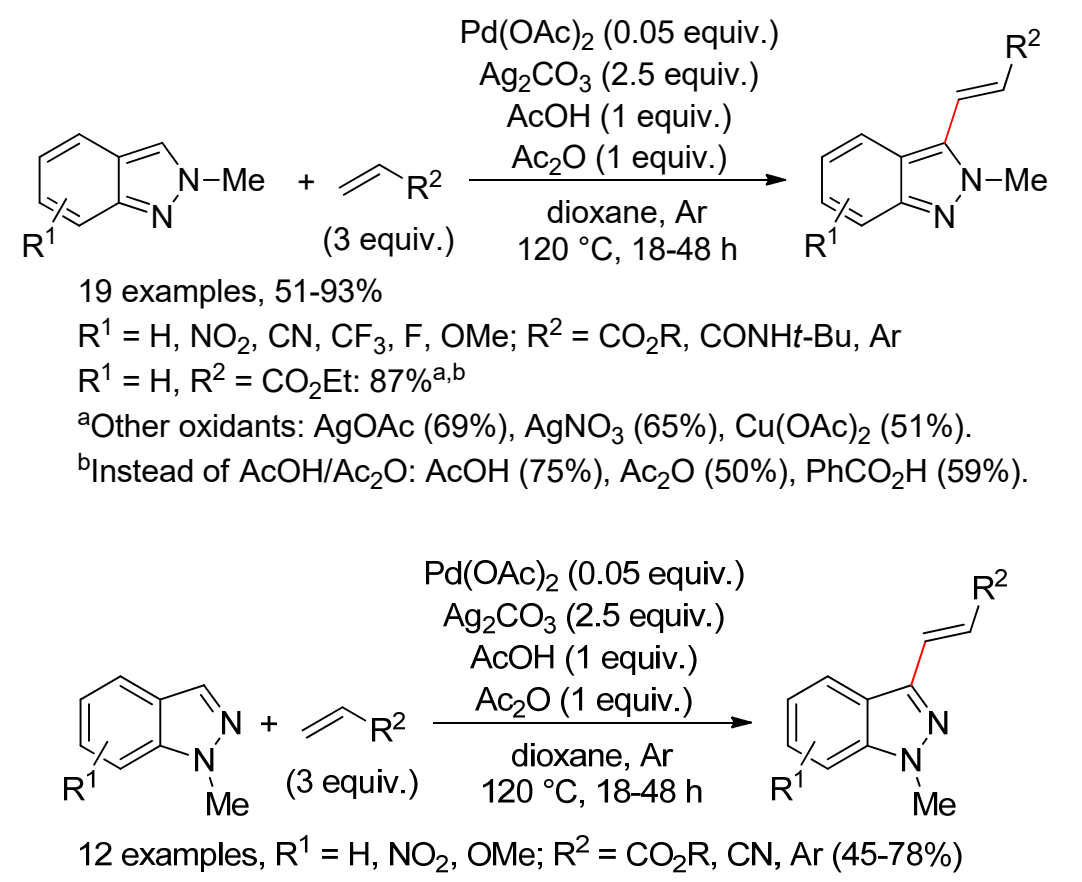

Su's team again used the mechanochemical strategy (Equation (50)) [25], but under different conditions for the C3-alkenylation of 1-methyl(or benzyl)-1H-indazoles (Equation (97)) [129]. $\mathrm{Cu}(\mathrm{OAc})_{2} \cdot \mathrm{H}_{2} \mathrm{O}$ and 1,10-phenanthroline were essential for good reactivity.

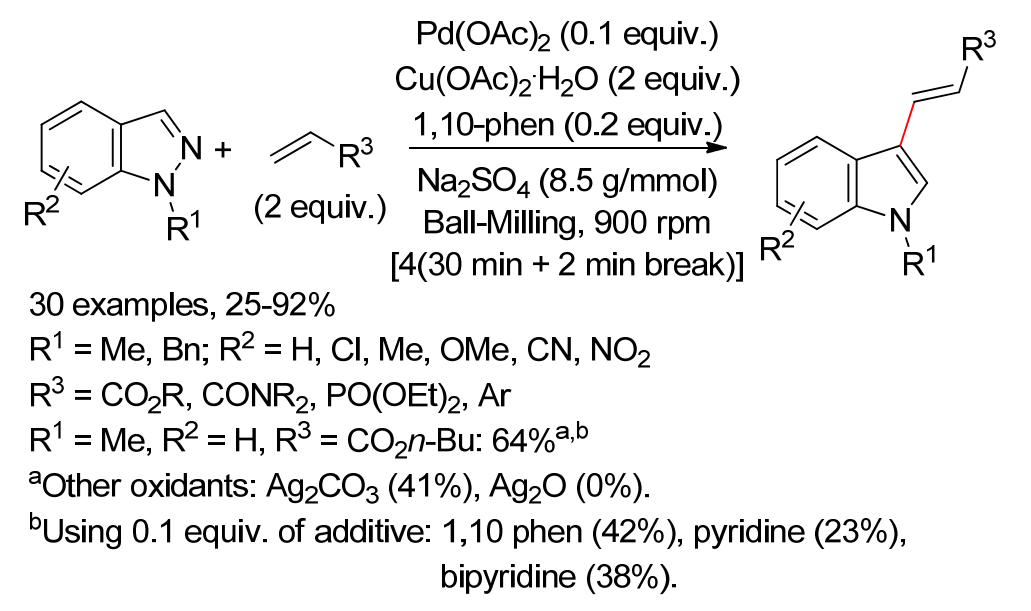

\subsection{Imidazoles}

The Ong procedure already used for other azoles (Equations (79), (84), and (88)) led to C2-styrenylation of 1-methyl-1H-imidazole (Equation (98)) [114].

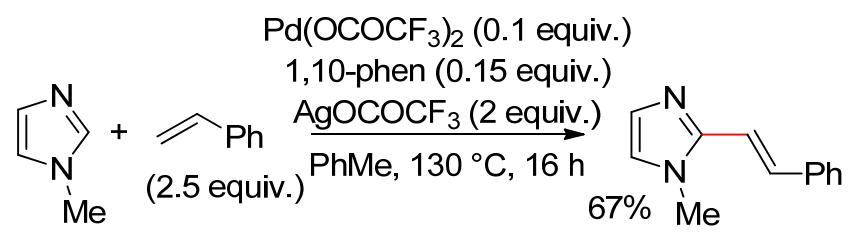




\subsection{Benzimidazole}

C2-styrenylation of 1-methyl-1H-benzo[d]imidazole was also performed using Ong's procedure (Equation (99)) [114].

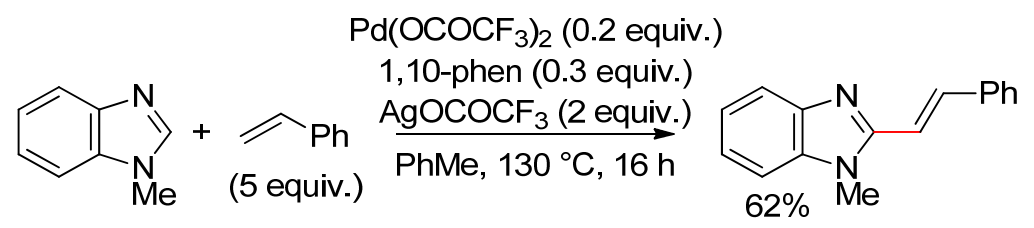

\subsection{Imidazo[1,2-a]pyridines}

Mahdavi and co-workers have recently reviewed different C3-functionalization of imidazo[1,2-a]pyridines [130].

An efficient and highly regioselective $\mathrm{Pd}^{\mathrm{II}}$-catalyzed C-3 alkenylation of imidazo[1,2-a]pyridines with acrylates and styrenes was developed by Cao's team using oxygen as the main oxidant [131]. Catalytic amounts of $\mathrm{Ag}_{2} \mathrm{CO}_{3}$ and stoichiometric quantities of both $\mathrm{AcOH}$ and $\mathrm{Ac}_{2} \mathrm{O}$ were required for optimum results. Acrylates and acrylonitrile tended to form $\beta$-products, while styrenes tended to form $\alpha$-products (Scheme 19). The authors proposed two different catalytic cycles like those of Scheme 1 , "arene activation" for the $\beta$-products and "alkene activation" for the $\alpha$-products.

Using oxygen as the sole oxidant, $\mathrm{Pd}(\mathrm{OAc})_{2}$-catalyzed 2-phenylimidazo[1,2-a]pyridine with styrene in DMSO provided the $\mathrm{C} 3$ branched adduct in low yield [132]. Changing the solvent for DMA with, especially $\mathrm{Bu}_{4} \mathrm{NBr}$ as additive, led to a fair yield (Equation (100)). Other substituted substrates and styrenes were reacted under the same conditions. The branched product was also obtained with 1-octene. Hajra and co-workers retained the mechanism of Scheme 1, alkene activation.

$$
\begin{aligned}
& \begin{array}{c}
\mathrm{Pd}(\mathrm{OAc})_{2} \text { (0.05 equiv.) } \\
\mathrm{Bu} 4 \mathrm{NBr}(2 \text { equiv.) }
\end{array} \\
& 18 \text { examples, } 59-78 \% \\
& \mathrm{R}^{1}=\mathrm{H}, i-\mathrm{Pr}, \mathrm{Ar} ; \mathrm{R}^{2}=\mathrm{H}, \mathrm{Me}, \mathrm{R}^{3}=\mathrm{Ar},\left(\mathrm{CH}_{2}\right)_{5} \mathrm{Me} \\
& \mathrm{R}^{1}=\mathrm{Ph}, \mathrm{R}^{2}=\mathrm{H}, \mathrm{R}^{3}=\mathrm{Ph}: 75 \% \text {, } \\
& \text { aOther solvents: DMSO (45\%), DMF (50\%), NMP (65\%), dioxane (10\%). } \\
& \text { bOther catalysts: } \mathrm{PdCl}_{2} \text { (15\%), } \mathrm{PdCl}_{2}\left(\mathrm{PPh}_{3}\right)_{2} \text { (trace). }
\end{aligned}
$$

Carrow's conditions used in Schemes 2 and 8 and Equations (36), (41), and (45) mediated the C3-olefination of imidazo[1,2-a]pyridine with butyl acrylate (Equation (101)) [45].

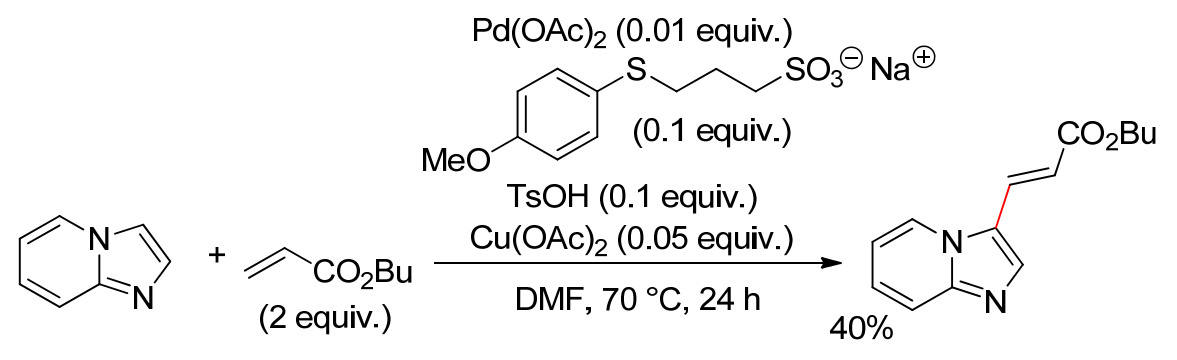




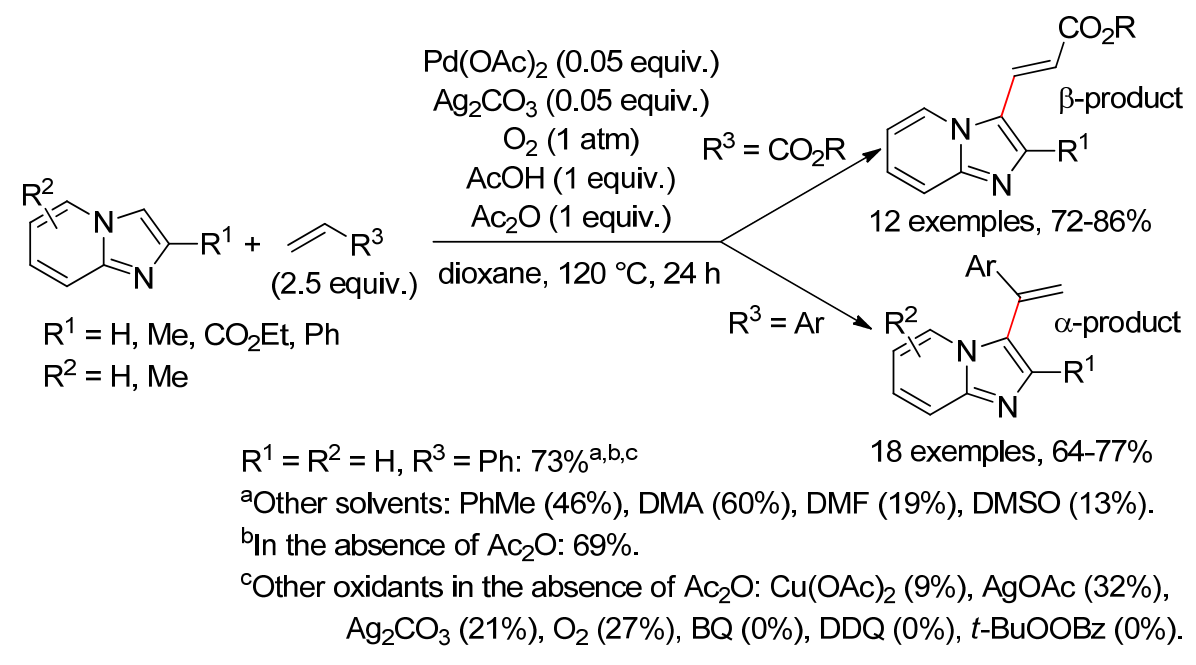

Scheme 19. Linear or branched cross-coupling product.

\subsection{Purines}

C8-olefination of biologically relevant purines occurred (Equations (102) and (103)) under experimental conditions used for DHRs of indolizines (Equation (67)), leading to fluorescent molecules with potential role in biological imaging [106].

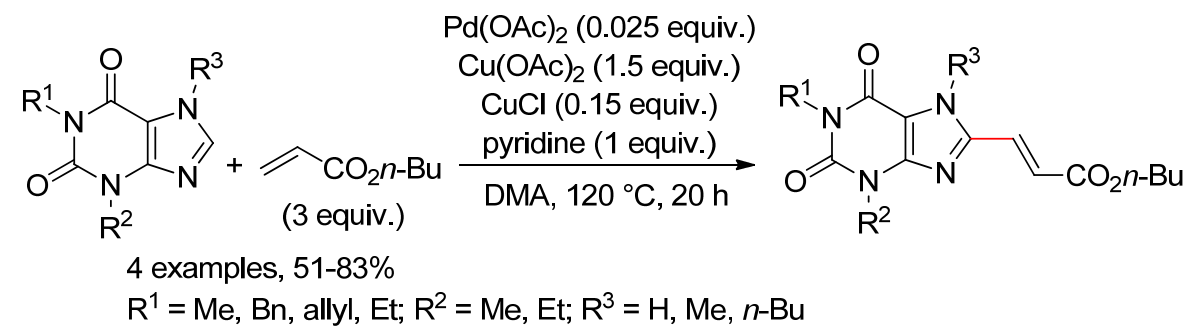

$$
\begin{gathered}
\mathrm{Pd}(\mathrm{OAC})_{2}(0.025 \text { equiv. }) \\
\mathrm{Cu}(\mathrm{OAC})_{2}(1.5-3 \text { equiv.) } \\
\mathrm{CuCl}(0.15 \text { equiv.) } \\
\text { pyridine }(1 \text { equiv.) }
\end{gathered}
$$

\section{9. $\mathrm{O}, \mathrm{N}, \mathrm{N}$-Arenes}

\subsection{1,3,4-Oxadiazoles}

The $\mathrm{Pd}\left(\mathrm{OCOCF}_{3}\right)_{2} / \mathrm{Ag}\left(\mathrm{OCOCF}_{3}\right)_{2} / 1,10$ phen would be the optimum association at $130{ }^{\circ} \mathrm{C}$ in toluene for the DHR of 2-aryl-1,3,4-oxadiazoles with vinyl(hetero)arenes (Equation (104)) [133].

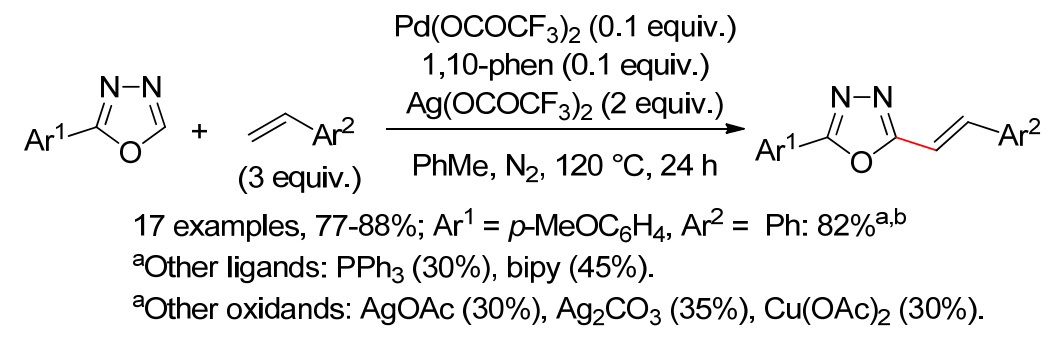




\subsection{Sydnones}

At room temperature, using AgOAc as the oxidant, 3-arylsydnones reacted with acrylates, acrylamide, allyl acetate, and styrenes leading to cross-coupling products in fair to good yields, while the 4-vinyl adduct arose with vinyl acetate (Scheme 20) [134]. Yang and Kuang did no comment on the cleavage mechanism of the C-OAc bond. We propose two plausible pathways based on Scheme 1 (Scheme 21). The DHR mechanism provides 21B and/or 21C through heteroarylpalladium complex 21A. $\beta$-H elimination from 21B would afford the cross-coupling adduct while $\beta$-HOAc elimination from $21 \mathrm{C}$ would lead to the vinyl adduct ${ }^{4}$. Another possibility is the formation of alkene complex 21D which underwent nucleophilic attack giving 21B and/or 21C. The addition of Heck reagent to vinyl acetate may add to $\alpha$ and $\beta$ positions, with slight preference for the $\beta$ [135], leading to mixture of products in a ratio depending on the experimental conditions $[36,116,136]$, while nucleophilic attack on the alkene complex could prefer the $\alpha$ position [119]. As the 3-arylsydnone/vinyl acetate cross-coupling product was not observed (Scheme 20), the 4-vinyl adduct would be rather formed via alkene activation.

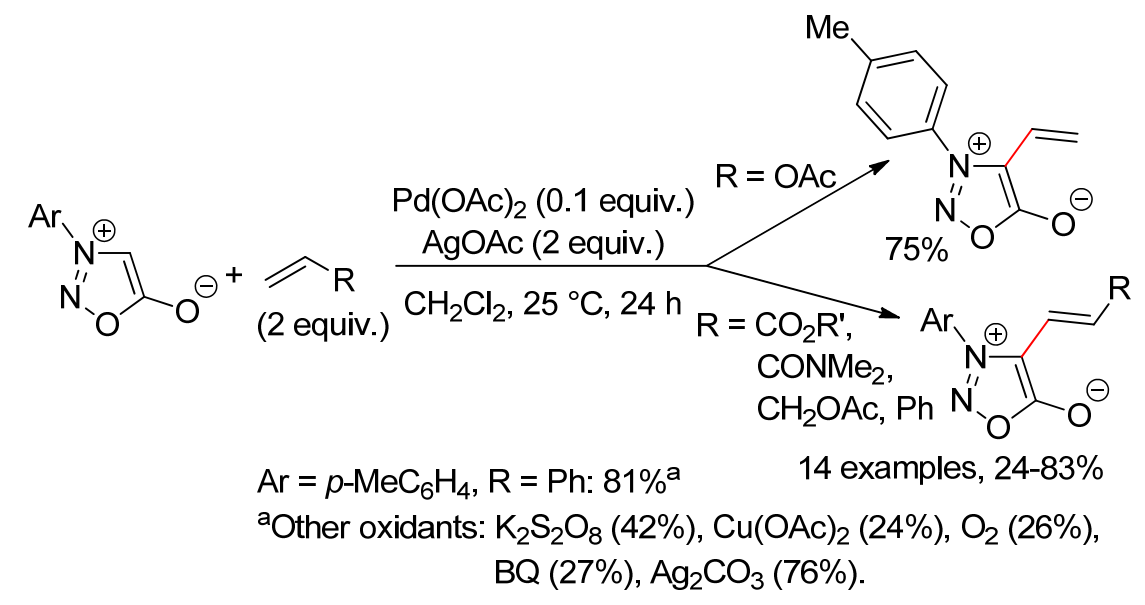

Scheme 20. DHRs of 3-arylsydnones.

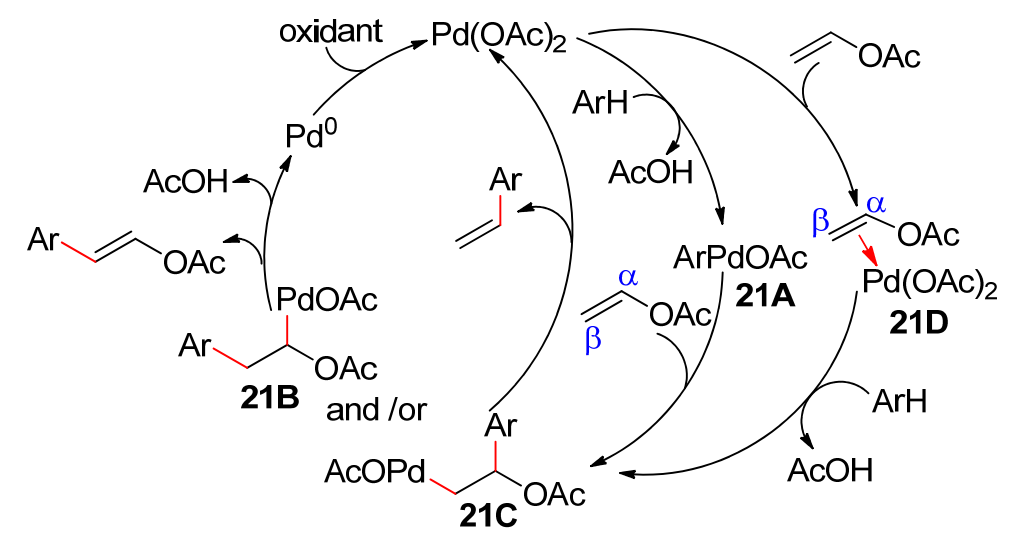

Scheme 21. Plausible pathways of the DHR with vinyl acetate. 


\section{0. $\mathrm{N}, \mathrm{N}, \mathrm{N}-$ Arenes}

\subsection{1,2,4-Triazoles}

Arylvinyltriazole nucleosides have been synthesized via DHR of the triazole core with a variety of styrenes (Equation (105)) [137].

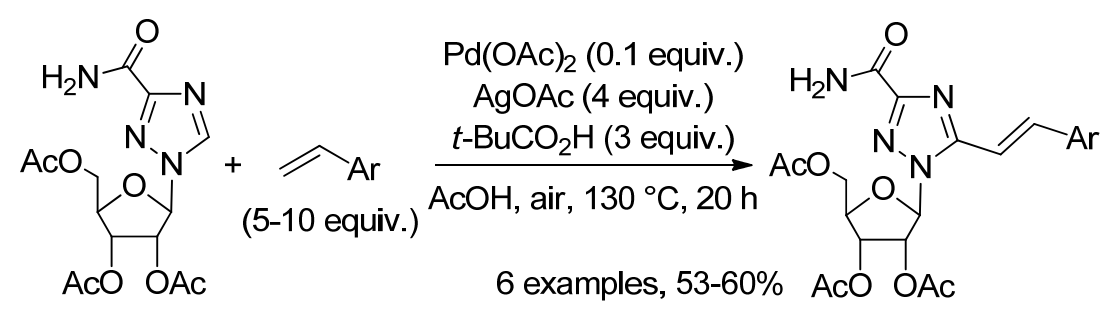

Kuang and co-workers reported the reluctance of 2-( $p$-tolyl)-2H-1,2,3-triazole towards the DHR with methyl acrylate under experimental conditions of Scheme 20 [138].

\subsection{1,2,3-Triazole N-Oxides}

The $\mathrm{Pd}(\mathrm{OAc})_{2} / \mathrm{Ag}_{2} \mathrm{CO}_{3} /$ pyridine system in $t-\mathrm{BuOH} /$ dioxane led to efficient DHRs of 2-aryl-2H-1,2,3-triazole 1-oxides with acrylates and styrene (Scheme 22) [138]. The presence of pyridine and the 1:4 ratio of $t-\mathrm{BuOH} /$ dioxane were essential for yields. The reaction with vinyl acetate provided a mixture of the cross-coupling and corresponding deacetoxy products, while that of 1-octene led to three isomers. Kuang and co-workers proposed that the three isomers were issued from the DHR (Scheme 1, arene activation). The formation of the branched product led us to suspect the possibility of a nucleophilic attack on the octene-coordinated palladium complex (Scheme 1, alkene activation). The mixture obtained from vinyl acetate does not allow the prioritization of a catalytic cycle (see Scheme 21 and discussion of Sub-chapter 9.2).

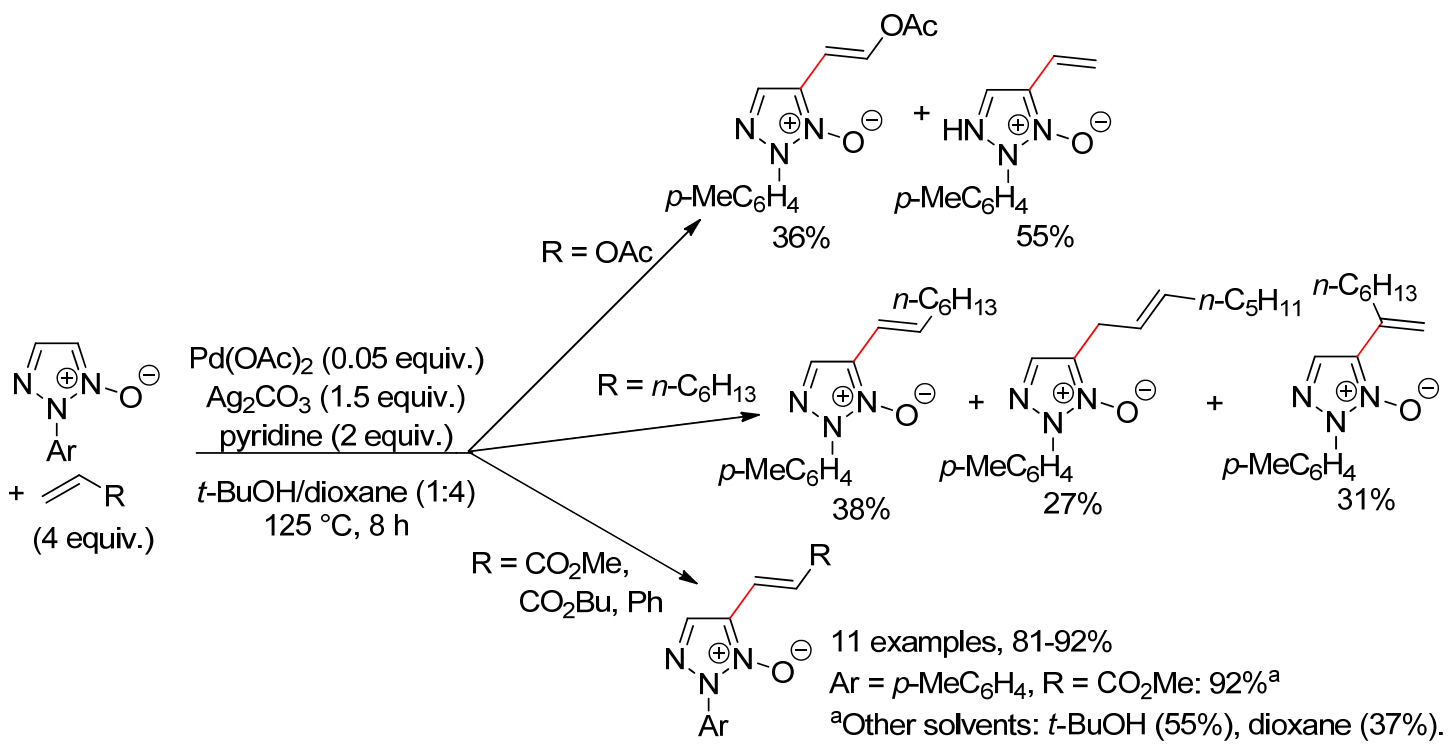

Scheme 22. Products depending on the olefinating agents.

\section{Conclusions and Remarks}

Undeniably, the development of DHRs of five-membered heteroarenes has greatly progressed in the last ten years. Their exclusive properties have attracted the attention of scientists all over the world, leading to processes that would be valuable tools for academic and industrial applications. 
A number of $\mathrm{Pd}(\mathrm{OAc})_{2}$-catalyzed methods seem almost identical. In fact, the oxidant, required for the turnover, and the solvent often varied with the substrate. Additives, which may also be ligands, have, in most cases, a decisive role on the efficiency. As the range of oxidants, solvent mixtures, and additives is large, it is not obvious to choose the right combination for a new reaction. Complexity increases with $\mathrm{N}$-heterocycles because their reactivity may depend on the $\mathrm{N}$-substitution. Even if the wide published procedures give valuable indications, the chemist should try and see to reach fine results from a new DHR.

Compared to traditional Heck reactions, the DHR's have a "green" character, because prefunctionalization of the starting aromatic partner is avoided, improving step economy, and also the high atom efficiency gained by formal removal of only the molecular hydrogen. Nevertheless, the DHR's are usually performed with an excess of heteroarene or alkenating reagent, and only a few methods use solely oxygen to regenerate the Pd active species. Consequently, expensive silver salts are often required as oxidants. Leading to wastes, these conditions decrease the "green" aspect of the procedures and their compatibility with the atom economy principle [139].

In our opinion, five publications are particularly important $[49,69,70,112,126]$ and complete the older Gaunt report [80]. One of them revealed a regioselectivity depending on the metal catalyst [49], while three others related regioselectivity mainly depending on solvent [69,70] or ligand [126]. The fifth publication disclosed a template directing the regioselectivity [112]. Another important report related regioselectivity depending on the substitution [72]. Although these reports concern DHRs of only a few substrates, they represent breakthroughs for researchers involved in the selective synthesis of regioisomers from the same starting material.

Author Contributions: Both J.M. and J.L.B. contributed to the manuscript, writing and literature research. All authors have read and agreed to the published version of the manuscript.

Funding: This research received no external funding.

Conflicts of Interest: The authors declare no conflict of interest.

\section{References}

1. Heck, R.F. Palladium Reagents in Organic Syntheses; Academic Press: London, UK, 1985; pp. 260-268.

2. Tsuji, J. Palladium Reagents and Catalysts, Innovations in Organic Synthesis; Wiley: Chichester, UK, 1995; pp. 55-59.

3. Tsuji, J. Palladium Reagents and Catalysts, New Perspectives for the 21st Century; Wiley: Chichester, UK, 2004.

4. The Mizoroki-Heck Reaction; Oestreich, M. (Ed.) Wiley: Chichester, UK, 2009.

5. Moritani, I.; Fujiwara, Y. Aromatic substitution of styrene-palladium chloride complex. Tetrahedron Lett. 1967, 8, 1119-1122. [CrossRef]

6. Fujiwara, Y.; Moritani, I.; Matsuda, M.; Teranishi, S. Aromatic substitution of olefins. IV Reaction with palladium metal and silver acetate. Tetrahedron Lett. 1968, 9, 3863-3865. [CrossRef]

7. Mizoroki, T.; Mori, K.; Ozaki, A. Arylation of olefin with aryl iodide catalyzed by palladium. Bull. Chem. Soc. Jpn. 1971, 44, 581. [CrossRef]

8. Julia, M.; Duteil, M. Condensation of aromatic halides with olefins catalyzed by palladium (0). Bull. Soc. Chim. Fr. 1973, 9-10, 2790.

9. Heck, R.F.; Nolley, J.P., Jr. Palladium-catalyzed vinylic hydrogen substitution reactions with aryl, benzyl, and styryl halides. J. Org. Chem. 1972, 37, 2320-2322. [CrossRef]

10. Le Bras, J.; Muzart, J. Intermolecular dehydrogenative Heck reactions. Chem. Rev. 2011, 111, 1170-1214. [CrossRef]

11. Weng, J.; Yu, Z.; Zhang, G. Direct oxidative coupling between unfunctionalized arene and olefin. Prog. Chem. 2012, 24, 523-544.

12. Wu, Y.; Wang, J.; Mao, F.; Kwong, F.Y. Palladium-catalyzed cross-dehydrogenative functionalization of C $\left(\mathrm{sp}^{2}\right)$-H bonds. Chem. Asian J. 2014, 9, 26-47. [CrossRef]

13. Maes, J.; Maes, B.U.W. A journey through metal-catalyzed C-H functionalization of heterocycles: Insights and trends. Adv. Heterocycl. Chem. 2016, 120, 137-194. 
14. Ping, L.; Chung, D.S.; Bouffard, J.; Lee, S.-G. Transition metal-catalyzed site- and regio-divergent C-H bond functionalization. Chem. Soc. Rev. 2017, 46, 4299-4328. [CrossRef]

15. Huang, C.-Y.; Kang, H.; Li, J.; Li, C.-J. En route to intermolecular cross-dehydrogenative coupling reactions. J. Org. Chem. 2019, 84, 12705-12721. [CrossRef] [PubMed]

16. Liu, Q.; Li, Q.; Ma, Y.; Jia, Y. Direct olefination at the C-4 position of tryptophan via C-H activation: Application to biomimetic synthesis of clavicipitic acid. Org. Lett. 2013, 15, 4528-4531. [CrossRef] [PubMed]

17. Guo, Y.; Shao, L.-Y.; Yu, K.-K.; Hu, Y.-H.; Liu, H.-W.; Liao, D.-H.; Ji, Y.-F. Palladium-catalyzed site-selective direct olefination of 6-electron-withdrawing group substituted 3-arylbenzo[d]isoxazoles. Org. Chem. Front. 2017, 4, 1962-1966. [CrossRef]

18. Leitch, J.A.; Bhonoah, Y.; Frost, C.G. Beyond C2 and C3: Transition-metal-catalyzed C-H functionalization of indole. ACS Catal. 2017, 7, 5618-5627. [CrossRef]

19. Broggini, G.; Beccalli, E.M.; Fasana, A.; Gazzola, S. Palladium-catalyzed dual C-H or N-H functionalization of unfunctionalized indole derivatives with alkenes and arenes. Beilstein J. Org. Chem. 2012, 8, 1730-1746. [CrossRef]

20. Thiery, E.; Harakat, D.; Le Bras, J.; Muzart, J. Pd-catalyzed oxidative coupling of alkylfurans with olefins through C-H activation: Synthesis of difurylalkanes. Organometallics 2008, 27, 3996-4004. [CrossRef]

21. Vasseur, A.; Harakat, D.; Muzart, J.; Le Bras, J. ESI-MS studies of the dehydrogenative Heck reaction of furans with acrylates using benzoquinone as the reoxidant and DMSO as the solvent. J. Org. Chem. 2012, 77, 5751-5758. [CrossRef]

22. Vasseur, A.; Harakat, D.; Muzart, J.; Le Bras, J. Aerobic dehydrogenative Heck reactions of heterocycles with styrenes: A negative effect of metallic co-oxidants. Adv. Synth. Catal. 2013, 355, 59-67. [CrossRef]

23. Rauf, W.; Brown, J.M. Reactive intermediates in catalytic alkenylation; pathways for Mizoroki-Heck, oxidative Heck and Fujiwara-Moritani reactions. Chem. Commun. 2013, 49, 8430-8440. [CrossRef]

24. Vasseur, A.; Laugel, C.; Harakat, D.; Muzart, J.; Le Bras, J. Ligand-promoted reactivity of alkenes in dehydrogenative Heck reactions of furans and thiophenes. Eur. J. Org. Chem. 2015, 2015, 944-948. [CrossRef]

25. Jia, K.-Y.; Yu, J.-B.; Jiang, Z.-J.; Su, W.-K. Mechanochemically activated oxidative coupling of indoles with acrylates through $\mathrm{C}-\mathrm{H}$ activation: Synthesis of 3-vinylindoles and $\beta, \beta$-diindolyl propionates and study of the mechanism. J. Org. Chem. 2016, 81, 6049-6055. [CrossRef] [PubMed]

26. Jones, R.C. Controlling reactivity in the Fujiwara-Moritani reaction: Examining solvent effects and the addition of 1,3-dicarbonyl ligands on the oxidative coupling of electron rich arenes and acrylates. Tetrahedron Lett. 2020, 61, 151471. [CrossRef]

27. Hu, H.; Liu, Y.; Zhong, H.; Zhu, Y.; Wang, C.; Ji, M. Heck-type cross-dehydrogenative coupling reactions of indolizines at the 3-position with electron-deficient alkenes through palladium-catalyzed C-H activation. Chem. Asian J. 2012, 7, 884-888. [CrossRef] [PubMed]

28. Petit, A.; Flygare, J.; Miller, A.T.; Winkel, G.; Ess, D.H. Transition-state metal aryl bond stability determines regioselectivity in palladium acetate mediated $\mathrm{C}-\mathrm{H}$ bond activation of heteroarenes. Org. Lett. 2012, 14, 3680-3683. [CrossRef]

29. Asano, R.; Moritani, I.; Fujiwara, Y.; Teranishi, S. Aromatic substitution of olefins. XIX. Reaction of five-membered heterocyclic aromatic compounds with styrene. Bull. Chem. Soc. Jpn. 1973, 46, 663. [CrossRef]

30. Kozhevnikov, I.V. Vinylation of 5-membered heterocycles by ethylene in the presence of palladium (II). React. Kinet. Catal. Lett. 1976, 5, 439-443. [CrossRef]

31. Fujiwara, Y.; Maruyama, O.; Yoshidomi, M.; Taniguchi, H. Palladium-catalyzed alkenylation of aromatic heterocycles with olefins. Synthesis of functionalized aromatic heterocycles. J. Org. Chem. 1981, 46, 851-855. [CrossRef]

32. Patra, P.; Ray, J.K.; Kar, G.K. Catalyst- and steric-controlled alkenylation via chemoselective C-H activation and C-Br activation in Heck reaction of methyl 1-(2-bromoaryl)-3-(2-furyl/thienyl)-5-oxopyrrolidine-2-carboxylates and diethyl 1-(2-bromoaryl)-3-(2-furyl/thienyl)-5-oxopyrrolidine-2,2-dicarboxylate derivatives. Tetrahedron Lett. 2010, 51, 3580-3582.

33. Taraban'ko, V.E.; Kozhevnikov, I.V.; Matveev, K.I. Palladium (II)-catalyzed arylation of ethylene in the presence of phosphorus-molybdenum-vanadium heteropoly acids. Kinet. Katal. 1978, 19, 1160-1166.

34. Tani, M.; Sakaguchi, S.; Ishii, Y. Pd (OAc) $)_{2}$-catalyzed oxidative coupling reaction of benzenes with olefins in the presence of molybdovanadophosphoric acid under atmospheric dioxygen and air. J. Org. Chem. 2004, 69, 1221-1226. [CrossRef] 
35. Zhao, J.; Huang, L.; Cheng, K.; Zhang, Y. Palladium-catalyzed alkenation of thiophenes and furans by regioselective C-H bond functionalization. Tetrahedron Lett. 2009, 50, 2758-2761. [CrossRef]

36. Le Bras, J.; Muzart, J. $\beta$-Elimination competitions leading to $\mathrm{C}=\mathrm{C}$ bonds from alkylpalladium intermediates. Tetrahedron 2012, 68, 10065-10113. [CrossRef]

37. Zhang, Y.; Li, Z.; Liu, Z.-Q. Pd-catalyzed olefination of furans and thiophenes with allyl esters. Org. Lett. 2012, 14, 226-229. [CrossRef] [PubMed]

38. Larock, R.C.; Hightower, T.R. Synthesis of unsaturated lactones via palladium-catalyzed cyclization of alkenoic acids. J. Org. Chem. 1993, 58, 5298-5300. [CrossRef]

39. Muzart, J. Oxidation adjacent to oxygen of alcohols catalyzed by palladium/dimethyl sulfoxide. In Comprehensive Organic Synthesis, 2nd ed.; Molander, G.A., Knochel, P., Eds.; Oxford: Oxford, UK; Elsevier: Amsterdam, The Netherlands, 2014; Volume 7, pp. 295-301.

40. Jiang, Z.; Zhang, L.; Dong, C.; Cai, Z.; Tang, W.; Li, H.; Xu, L.; Xiao, J. Palladium-catalyzed highly regioselective arylation of allylamines with thiophenes and furans. Adv. Synth. Catal. 2012, 354, 3225-3230. [CrossRef]

41. Huang, L.; Qi, J.; Wu, X.; Wu, W.; Jiang, H. Aerobic oxidative coupling between carbon nucleophiles and allylic alcohols: A strategy to construct $\beta$-(hetero) aryl ketones and aldehydes through hydrogen migration. Chem. Eur. J. 2013, 19, 15462-15466. [CrossRef]

42. Muzart, J. Palladium-catalysed reactions of alcohols, Part B: Formation of C-C and C-N bonds from unsaturated alcohols. Tetrahedron 2005, 61, 4179-4212. [CrossRef]

43. Álvarez-Casao, Y.; Fernández-Ibáñez, M.Á. S,O-Ligand-promoted Pd-catalyzed C-H olefination of thiophenes. Eur. J. Org. Chem. 2019, 2019, 1842-1845. [CrossRef]

44. Li, Y.; Shen, Z.; Huang, M.; Zhang, J.; Kim, J.K.; Wu, Y. Highly catalytic activity of bis(alkoxo)-palladium complexes for Fujiwara-Moritani. Chin. J. Org. Chem. 2018, 38, 200-207. [CrossRef]

45. Gorsline, B.J.; Wang, L.; Ren, P.; Carrow, B.P. C-H alkenylation of heteroarenes: Mechanism, rate, and selectivity changes enabled by thioether ligands. J. Am. Chem. Soc. 2017, 139, 9605-9614. [CrossRef]

46. Wen, Z.-K.; Zhao, Z.-K.; Wang, N.-J.; Chen, Z.-L.; Chao, J.-B.; Feng, L.-H. Palladium-catalyzed controllable reductive/oxidative Heck coupling between cyclic enones and thiophenes via C-H activation. Org. Lett. 2019, 21, 9545-9549. [CrossRef] [PubMed]

47. Wang, S.; Deng, G.; Gu, J.; Hua, W.; Jia, X.; Xi, K. In site preparation of Pd (II)-MoS 2 complex: A new high-efficiency catalyst for alkenylation of heteroaromatics by direct $\mathrm{C}-\mathrm{H}$ bond activation. Appl. Catal. A Gen. 2015, 508, 80-85. [CrossRef]

48. Van Velthoven, N.; Henrion, M.; Dallenes, J.; Krajnc, A.; Bugaev, A.L.; Liu, P.; Bals, S.; Soldatov, A.V.; Mali, G.; De Vos, D.E. S,O-functionalized metal-organic frameworks as heterogeneous single-site catalysts for the oxidative alkenylation of arenes via C-H activation. ACS Catal. 2020, 10, 5077-5085. [CrossRef]

49. Gao, S.; Wu, Z.; Wu, F.; Lin, A.; Yao, H. Catalyst-controlled regiodivergent dehydrogenative Heck reaction of 4-arylthiophene/furan-3-carboxylates. Adv. Synth. Catal. 2016, 358, 4129-4135. [CrossRef]

50. Della $\mathrm{Ca}^{\prime}$, N.; Fontana, M.; Motti, E.; Catellani, M. Pd/norbornene: A winning combination for selective aromatic functionalization via C-H bond activation. Acc. Chem. Res. 2016, 49, 1389-1400. [CrossRef]

51. Cheng, H.-G.; Chen, S.; Chen, R.; Zhou, Q. Palladium (II)-initiated Catellani-type reactions. Angew. Chem. Int. Ed. 2019, 58, 5832-5844. [CrossRef]

52. Wang, J.; Dong, G. Palladium/norbornene cooperative catalysis. Chem. Rev. 2019, 119, 7478-7528. [CrossRef]

53. Li, R.; Zhou, Y.; Xu, X.; Dong, G. Direct vicinal difunctionalization of thiophenes enabled by the palladium/norbornene cooperative catalysis. J. Am. Chem. Soc. 2019, 141, 18958-18963. [CrossRef]

54. Catellani, M.; Fagnola, M.C. Palladacycles as intermediates for selective dialkylation of arenes and subsequent fragmentation. Angew. Chem. Int. Ed. Engl. 1995, 33, 2421-2422. [CrossRef]

55. Kim, B.S.; Lee, S.Y.; Youn, S.-W. Pd-catalyzed sequential C-C and C-N bond formations for the synthesis of $\mathrm{N}$-heterocycles: Exploiting protecting group-directed C-H activation under modified reaction conditions. Chem. Asian J. 2011, 6, 1952-1957. [CrossRef]

56. Lu, Y.; Wang, D.-H.; Engle, K.M.; Yu, J.-Q. Pd (II)-catalyzed hydroxyl-directed C-H olefination enabled by monoprotected amino acid ligands. J. Am. Chem. Soc. 2010, 132, 5916-5921. [CrossRef] [PubMed]

57. Li, G.; Leow, D.; Wan, L.; Yu, J.-Q. Ether-directed ortho-C-H olefination with a palladium (II)/monoprotected amino acid catalyst. Angew. Chem. Int. Ed. 2013, 52, 1245-1247. [CrossRef] [PubMed]

58. Huang, Q.; Ke, S.; Qiu, L.; Zhang, X.; Lin, S. Palladium (II)/polyoxometalate-catalyzed direct alkenylation of benzofurans under atmospheric dioxygen. Chem. Cat. Chem. 2014, 6, 1531-1534. [CrossRef] 
59. Fu, X.; Yang, J.; Deng, K.; Shao, L.; Xia, C.; Ji, Y. Tandem C-C/C-N formation via palladium-catalyzed C-H activation/styrenation and sequential annulation of O-methylketoxime with styrenes. Org. Lett. 2019, 21, 3505-3509. [CrossRef] [PubMed]

60. Hosokawa, T.; Shimo, N.; Maeda, K.; Sonoda, A.; Murahashi, S.I. Palladium-induced pyridine synthesis from unsaturated ketoximes. Tetrahedron Lett. 1976, 17, 383-386. [CrossRef]

61. Kitamura, M.; Narasaka, K. Synthesis of aza-heterocycles from oximes by amino-Heck reaction. Chem. Rec. 2002, 2, 268-277. [CrossRef]

62. Morita, T.; Satoh, T.; Miura, M. Palladium (II)-catalyzed direct C-H alkenylation of thienothiophene and related fused heteroarenes. Org. Lett. 2015, 17, 4384-4387. [CrossRef]

63. Kasahara, A.; Izumi, T.; Yodono, M.; Saito, R.; Takeda, T.; Sugawara, T. Arylation and vinylation reactions of benzo[b]furan via organopalladium intermediates. Bull. Chem. Soc. Jpn. 1973, 46, 1220. [CrossRef]

64. Maehara, A.; Satoh, T.; Miura, M. Palladium-catalyzed direct oxidative vinylation of thiophenes and furans under weakly basic conditions. Tetrahedron 2008, 64, 5982-5986. [CrossRef]

65. Aouf, C.; Thiery, E.; Le Bras, J.; Muzart, J. Palladium-catalyzed dehydrogenative coupling of furans with styrenes. Org. Lett. 2009, 11, 4096-4099. [CrossRef]

66. Jia, C.; Lu, W.; Kitamura, T.; Fujiwara, Y. Highly efficient Pd-catalyzed coupling of arenes with olefins in the presence of tert-butyl hydroperoxide as oxidant. Org. Lett. 1999, 1, 2097-2100. [CrossRef]

67. Tsuji, J.; Nagashima, H. Palladium-catalyzed oxidative coupling of aromatic compounds with olefins using t-butyl perbenzoate as hydrogen acceptor. Tetrahedron 1984, 40, 2699-2702. [CrossRef]

68. Yin, B.; Fu, M.; Wang, L.; Liu, J.; Zhu, Q. Dual ligand-promoted palladium-catalyzed nondirected C-H alkenylation of aryl ethers. Chem. Commun. 2020, 56, 3293-3296. [CrossRef] [PubMed]

69. Su, Y.; Zhou, H.; Chen, J.; Xu, J.; Wu, X.; Lin, A.; Yao, H. Solvent-controlled switchable C-H alkenylation of 4-aryl-1H-pyrrole-3-carboxylates: Application to the total synthesis of ( \pm )-rhazinilam. Org. Lett. 2014, 16, 4884-4887. [CrossRef] [PubMed]

70. Su, Y.; Gao, S.; Huang, Y.; Lin, A.; Yao, H. Solvent-controlled C2/C5-regiodivergent alkenylation of pyrroles. Chem. Eur. J. 2015, 21, 15820-15825. [CrossRef]

71. Zierkiewicz, W.; Privalov, T. A theoretical study of the essential role of DMSO as a solvent/ligand in the Pd $(\mathrm{OAc})_{2}$ /DMSO catalyst system for aerobic oxidation. Organometallics 2005, 24, 6019-6028. [CrossRef]

72. Laha, J.K.; Bhimpuria, R.A.; Mule, G.B. Site-selective oxidative C4 alkenylation of (NH)-pyrroles bearing an electron-withdrawing C2 group. Chem. Cat. Chem. 2017, 9, 1092-1096. [CrossRef]

73. Duan, J.-H.; Mi, R.-J.; Sun, J.; Zhou, M.-D. Regioselective C5 alkenylation of 2-acylpyrroles via Pd (II)-catalyzed C-H bond activation. Org. Chem. Front. 2018, 5, 162-165. [CrossRef]

74. Wang, L.; Guo, W.; Zhang, X.-X.; Xia, X.-D.; Xiao, W.J. Synthesis of indolo [1,2-a]quinoxalines via a Pd-catalyzed regioselective C-H olefination/cyclization sequence. Org. Lett. 2012, 14, 740-743. [CrossRef]

75. Wang, J.; Wu, O.; Gong, O.; Cheng, K.; Liu, O.; Yu, C.; Hao, E.; Jiao, L. Direct $\beta$-selective styrylation of BODIPY dyes via palladium(II)-catalyzed C-H functionalization. Adv. Synth. Catal. 2019, 361, 769-777. [CrossRef]

76. Wang, J.; Li, Y.; Gong, Q.; Wang, H.; Hao, E.; Lo, P.-C.; Jiao, L. $\beta$-AlkenylBODIPY dyes: Regioselective synthesis via oxidative $\mathrm{C}-\mathrm{H}$ olefination, photophysical properties, and bioimaging studies. J. Org. Chem. 2019, 84, 5078-5090. [CrossRef] [PubMed]

77. Petrini, M. Regioselective direct C-alkenylation of indoles. Chem. Eur. J. 2017, 23, 16115-16151. [CrossRef] [PubMed]

78. Sandtorv, A.H. Transition metal-catalyzed C-H activation of indoles. Adv. Synth. Catal. 2015, 357, $2403-2435$. [CrossRef]

79. Koubachi, J.; Brahmi, N.E.; Guillaumet, G.; Kazzouli, S.E. Oxidative alkenylation of fused bicyclic heterocycles. Eur. J. Org. Chem. 2019, 2019, 2568-2586. [CrossRef]

80. Grimster, N.P.; Gauntlett, C.; Godfrey, C.R.A.; Gaunt, M.J. Palladium-catalyzed intermolecular alkenylation of indoles by solvent-controlled regioselective C-H functionalization. Angew. Chem. Int. Ed. 2005, 44, 3125-3129. [CrossRef] [PubMed]

81. Chen, W.-L.; Gao, Y.-R.; Mao, S.; Zhang, Y.-L.; Wang, Y.-F.; Wang, Y.-Q. Palladium-catalyzed intermolecular C3 alkenylation of indoles using oxygen as the oxidant. Org. Lett. 2012, 14, 5920-5923. [CrossRef] 
82. Steinhoff, B.A.; Fix, S.R.; Stahl, S.S. Mechanistic study of alcohol oxidation by the $\mathrm{Pd}(\mathrm{OAc})_{2} / \mathrm{O}_{2} / \mathrm{DMSO}$ catalyst system and implications for the development of improved aerobic oxidation catalysts. J. Am. Chem. Soc. 2002, 124, 766-767. [CrossRef]

83. Huang, Q.; Song, Q.; Cai, J.; Zhang, X.; Lin, S. Palladium (II)/polyoxometalate-catalyzed direct C-3 alkenylation of indoles using dioxygen as the terminal oxidant. Adv. Synth. Catal. 2013, 355, 1512-1516. [CrossRef]

84. An, Y.L.; Yang, Z.H.; Zhang, H.H.; Zhao, S.-Y. Palladium-catalyzed tandem regioselective oxidative coupling from indoles and maleimides: One-pot synthesis of indolopyrrolocarbazoles and related indolylmaleimides. Org. Lett. 2016, 18, 152-155. [CrossRef]

85. Verma, A.K.; Danodia, A.K.; Saunthwal, R.K.; Patel, M.; Choudhary, D. Palladium-catalyzed triple successive C-H functionalization: Direct synthesis of functionalized carbazoles from indoles. Org. Lett. 2015, 17, 3658-3661. [CrossRef]

86. Cirujano, F.G.; Leo, P.; Vercammen, J.; Smolders, S.; Orcajo, G.; De Vos, D.E. MOFs extend the lifetime of $\mathrm{Pd}(\mathrm{II})$ catalyst for room temperature alkenylation of enamine-like arenes. Adv. Synth. Catal. 2018, 360, 3872-3876. [CrossRef]

87. Hermann, G.N.; Becker, P.; Bolm, C. Mechanochemical rhodium (III)-catalyzed C-H bond functionalization of acetanilides under solventless conditions in a ball mill. Angew. Chem. Int. Ed. 2015, 54, 7414-7417. [CrossRef]

88. Mei, T.S.; Werner, E.W.; Burckle, A.J.; Sigman, M.S. Enantioselective redox-relay oxidative Heck arylations of acyclic alkenyl alcohols using boronic acids. J. Am. Chem. Soc. 2013, 135, 6830-6833. [CrossRef]

89. Mei, T.-S.; Patel, H.H.; Sigman, M.S. Enantioselective construction of remote quaternary stereocentres. Nature 2014, 508, 340-344. [CrossRef]

90. Zhang, C.; Santiago, C.B.; Crawford, J.M.; Sigman, M.S. Enantioselective dehydrogenative Heck arylations of trisubstituted alkenes with indoles to construct quaternary stereocenters. J. Am. Chem. Soc. 2015, 137, 15668-15671. [CrossRef] [PubMed]

91. Li, Y.; Xue, D.; Lu, W.; Fan, X.; Wang, C.; Xiao, J. 3-Acylindoles via palladium-catalyzed regioselective arylation of electron-rich olefins with indoles. RSC Adv. 2013, 3, 11463-11466. [CrossRef]

92. Daves, G.D., Jr.; Hallberg, A. 1.2-Additions to heteroatom-substituted olefins by organopalladium reagents. Chem. Rev. 1989, 89, 1433-1445. [CrossRef]

93. Cabri, W.; Candiani, I. Recent developments and new perspectives in the Heck reaction. Acc. Chem. Res. 1995, 28, 2-7. [CrossRef]

94. Mo, J.; Xu, L.; Xiao, J. Ionic liquid-promoted, highly regioselective Heck arylation of electron-rich olefins by aryl halides. J. Am. Chem. Soc. 2005, 127, 751-760. [CrossRef]

95. Guo, T.L.; Jiang, Q.B.; Huang, F.; Chen, J.P.; Yu, Z.K. Palladium-catalyzed, copper-mediated construction of benzene rings from the reactions of indoles with in situ generated enones. Org. Chem. Front. 2014, 1, 707-711. [CrossRef]

96. Takeda, D.; Hirano, K.; Satoh, T.; Miura, M. Palladium-catalyzed direct arylation and alkenylation of 3-(indol-3-yl)propionic acids through C-H bond cleavage. Heterocycles 2014, 88, 275-286.

97. Terrey, M.J.; Holmes, A.; Perry, C.C.; Cross, W.B. C-H olefination of tryptophan residues in peptides: Control of residue selectivity and peptide-amino acid cross-linking. Org. Lett. 2019, 21, 7902-7907. [CrossRef] [PubMed]

98. Wang, H.; Zhou, Z.-X.; Kurmoo, M.; Liu, Y.-J.; Zeng, M.-H. Carboxylate-assisted Pd (II)-catalyzed ortho-C-H and remote $\mathrm{C}-\mathrm{H}$ activation: Economical synthesis of pyrano [4,3-b]indol-1(5H)-ones. Org. Lett. 2019, 21, 2847-2850. [CrossRef] [PubMed]

99. Fu, X.-P.; Tang, S.-B.; Yang, J.-Y.; Zhang, L.-L.; Xia, C.-C.; Ji, Y.-F. Cascade reaction for the synthesis of carbolines from $\mathrm{O}$-methylketoximes and styrenes via palladium-catalyzed $\mathrm{C}-\mathrm{H}$ activation and sequential annulation. Eur. J. Org. Chem. 2019, 5974-5977. [CrossRef]

100. Albarghouti, G.; Kotikalapudi, R.; Lankri, D.; Valerio, V.; Tsvelikhovsky, D. Cascade Pd (II)-catalyzed Wacker lactonization-Heck reaction: Rapid assembly of spiranoid lactones. Chem. Commun. 2016, 52, 3095-3098. [CrossRef] [PubMed]

101. Yan, Z.-L.; Chen, W.-L.; Gao, Y.-R.; Mao, S.; Zhang, Y.-L.; Wang, Y.-Q. Palladium-catalyzed intermolecular C-2 alkenylation of indoles using oxygen as the oxidant. Adv. Synth. Catal. 2014, 356, 1085-1092. [CrossRef]

102. Saunthwal, R.K.; Patel, M.; Kumar, S.; Danodia, A.K.; Verma, A.K. Pd (II)-catalyzed C-H activation of styrylindoles: Short, efficient, and regioselective synthesis of functionalized carbazoles. Chem. Eur. J. 2015, 21, 18601-18605. [CrossRef] 
103. Ozaki, K.; Zhang, H.; Ito, H.; Lei, A.; Itami, K. One-shot indole-to-carbazole $\pi$-extension by a Pd-Cu-Ag trimetallic system. Chem. Sci. 2013, 4, 3416-3420. [CrossRef]

104. Laha, J.K.; Dayal, N. A tandem approach to functionalized carbazoles from indoles via two successive regioselective oxidative Heck reactions followed by thermal electrocyclization. Org. Lett. 2015, 17, 4742-4745. [CrossRef]

105. Kannaboina, P.; Kumar, K.A.; Das, P. Site-selective intermolecular oxidative C-3 alkenylation of 7-azaindoles at room temperature. Org. Lett. 2016, 18, 900-903. [CrossRef]

106. Huang, Y.; Song, F.; Wang, Z.; Xi, P.; Wu, N.; Wang, Z.; Lan, J.; You, J. Dehydrogenative Heck coupling of biologically relevant $\mathrm{N}$-heteroarenes with alkenes: Discovery of fluorescent core frameworks. Chem. Commun. 2012, 48, 2864-2866. [CrossRef] [PubMed]

107. Lu, M.; Shi, F.; Ji, M.; Kan, Y.; Hu, H. Palladium catalyzed C-H olefination of indolizines at the 1-position with molecular oxygen as the terminal oxidant. Asian J. Chem. 2019, 8, 1555-1560. [CrossRef]

108. Yang, Y.; Chen, L.; Zhang, Z.; Zhang, Y. Palladium-catalyzed oxidative C-H bond and C=C double bond cleavage: C-3 acylation of indolizines with,$\pm \beta$-unsaturated carboxylic acids. Org. Lett. 2011, 13, 1342-1345. [CrossRef] [PubMed]

109. Chen, S.-Y.; Sahoo, S.K.; Huang, C.L.; Chan, T.-H.; Cheng, Y.-J. Pd (II)-catalyzed direct dehydrogenative mono- and diolefination of selenophenes. Org. Lett. 2020, 22, 2318-2322. [CrossRef]

110. Li, Z.; Ma, L.; Tang, C.; Xu, J.; Wu, X.; Yao, H. Palladium (II)-catalyzed oxidative Heck coupling of thiazole-4-carboxylates. Tetrahedron Lett. 2011, 52, 5643-5647. [CrossRef]

111. Liu, W.; Yu, X.; Kuang, C. Palladium-catalyzed C-2 selective olefination of thiazoles. Org. Lett. 2014, 16, 1798-1801. [CrossRef]

112. Achar, T.K.; Biswas, J.P.; Porey, S.; Pal, T.; Ramakrishna, K.; Maiti, S.; Maiti, D. Palladium-catalyzed template directed C-5 selective olefination of thiazoles. J. Org. Chem. 2019, 84, 8315-8321. [CrossRef]

113. Chappell, B.; Dedman, N.; Wheeler, S. Studies on the palladium-catalysed direct alkenylation of 1,2-azoles. Tetrahedron Lett. 2011, 52, 3223-3225. [CrossRef]

114. Lee, W.-C.; Wang, T.-H.; Ong, T.-G. Ligand promoted Pd-catalyzed dehydrogenative alkenylation of hetereoarenes. Chem. Commun. 2014, 50, 3671-3673. [CrossRef]

115. Yi, C.; Hua, R. An efficient palladium-catalyzed Heck coupling of aryl chlorides with alkenes. Tetrahedron Lett. 2006, 47, 2573-2576. [CrossRef]

116. Ruan, J.; Xiao, J. From $\alpha$-arylation of olefins to acylation with aldehydes: A journey in regiocontrol of the Heck reaction. Acc. Chem. Res. 2011, 44, 614-626. [CrossRef] [PubMed]

117. Jensen, K.H.; Sigman, M.S. Mechanistic approaches to palladium-catalyzed alkene difunctionalization reactions. Org. Biomol. Chem. 2008, 6, 4083-4088. [CrossRef] [PubMed]

118. Kocovsky, P.; Bäckvall, J.-E. The syn/anti-dichotomy in the palladium-catalyzed addition of nucleophiles to alkenes. Chem. Eur. J. 2015, 21, 36-56. [CrossRef] [PubMed]

119. White, D.R.; Bornowski, E.C.; Wolfe, J.P. Pd-catalyzed C-C, C-N, and C-O bond-forming difunctionalization reactions of alkenes bearing tethered aryl/alkenyl triflates. Isr. J. Chem. 2020, 60, 259-267. [CrossRef]

120. Liu, W.; Wang, S.; Zhan, H.; Lin, J.; He, P.; Jiang, Y. Highly regioselective palladium-catalyzed direct alkenylation of thiazolo[3,2-b]-1,2,4-triazoles via C-H activation. Tetrahedron Lett. 2014, 55, 3549-3552. [CrossRef]

121. Huang, G.; Teng, M.; Liu, B.; Rong, M.; Liu, Y.; Chen, Y. Palladium-catalyzed site-selective C-H alkenylation of imidazo [2,1-b]thiazoles. J. Organomet. Chem. 2016, 818, 163-167. [CrossRef]

122. Cui, S.; Wojtas, L.; Antilla, J.C. Pd-catalyzed C4-olefination of oxazoles via C-H bond activation: Divergent synthesis of functionalized amino alcohol and amino acid derivatives. Org. Lett. 2011, 13, 5040-5043. [CrossRef]

123. Lu, Z.; Luo, F.; Wang, L.; Zhu, G. Palladium-catalyzed direct alkenylation of 2-oxazolones: An entry to 3,4,5-trisubstituted 2-oxazolones. J. Org. Chem. 2013, 78, 10894-10901. [CrossRef]

124. Wang, X.; Fang, X.; Xiao, H.; Gong, D.; Yang, X.; Wu, F. A new and direct route to 3-fluoromethyl substituted pyrazol-4-acrylates via Pd-catalyzed C-H activation. Tetrahedron 2013, 69, 6993-7000. [CrossRef]

125. Han, S.J.; Kim, H.T.; Joo, J.M. Direct C-H alkenylation of functionalized pyrazoles. J. Org. Chem. 2016, 81, 689-698. [CrossRef] 
126. Kim, H.T.; Ha, H.; Kang, G.; Kim, O.S.; Ryu, H.; Biswas, A.K.; Lim, S.M.; Baik, M.-H.; Joo, J.M. Ligand-controlled regiodivergent $\mathrm{C}-\mathrm{H}$ alkenylation of pyrazoles and its application to the synthesis of indazoles. Angew. Chem. Int. Ed. 2017, 56, 16262-16266. [CrossRef] [PubMed]

127. Yang, Y.; Gong, H.; Kuang, C. Room-temperature direct alkenylation of 5-pyrazolones. Eur. J. Org. Chem. 2013, 2013, 5276-5281. [CrossRef]

128. Naas, M.; El Kazzouli, S.; Essassi, E.M.; Bousmina, M.; Guillaumet, G. Palladium-catalyzed oxidative direct C3- and C7-alkenylations of indazoles: Application to the synthesis of gamendazol. Org. Lett. 2015, 17, 4320-4323. [CrossRef] [PubMed]

129. Yu, J.; Yang, X.; Wu, C.; Su, W. Palladium-catalyzed C-H/C-H cross-coupling by mechanochemistry: Direct alkenylation and heteroarylation of N1-protected $1 H$-indazoles. J. Org. Chem. 2020, 85, 1009-1021. [CrossRef] [PubMed]

130. Tashrifi, Z.; Mohammadi-Khanaposhtani, M.; Larijani, B.; Mahdavi, M. C3-Functionalization of imidazo [1,2-a]pyridines. Eur. J. Org. Chem. 2020, 2020, 269-284. [CrossRef]

131. Cao, H.; Lei, S.; Liao, J.; Huang, J.; Qiu, H.; Chen, Q.; Qiu, S.; Chen, Y. Palladium (II)-catalyzed intermolecular oxidative C-3 alkenylations of imidazo[1,2-a]pyridines by substrate-controlled regioselective C-H functionalization. RSC Adv. 2014, 4, 50137-50140. [CrossRef]

132. Ghosh, M.; Naskar, A.; Mitra, S.; Hajra, A. Palladium-catalyzed $\alpha$-selective alkenylation of imidazo [1,2-a]pyridines through aerobic cross-dehydrogenative coupling reaction. Eur. J. Org. Chem. 2015, 2015, 715-718. [CrossRef]

133. Salvanna, N.; Reddy, P.R.; Das, B. Palladium-catalyzed cross-coupling of 1,3,4-oxadiazoles and styrenes: An efficient method to synthesize 2-alkenyl-1,3,4-oxadiazoles. Synlett 2018, 29, 71-74. [CrossRef]

134. Yang, Y.; Kuang, C. Room-temperature direct alkenylation of 3-arylsydnones. Eur. J. Org. Chem. 2014, 2014, 7810-7813. [CrossRef]

135. Heck, R.F. The palladium-catalyzed arylation of enol esters, ethers, and halides. A new synthesis of 2-aryl aldehydes and ketones. J. Am. Chem. Soc. 1968, 90, 5535-5542. [CrossRef]

136. Kasahara, A.; Izumi, T.; Fukuda, N. The palladium-catalyzed phenylation of enol esters with iodobenzene. Bull. Chem. Soc. Jpn. 1977, 50, 551-552. [CrossRef]

137. Tang, J.; Cong, M.; Xia, Y.; Quéléver, G.; Fan, Y.; Qu, F.; Peng, L. Pd-catalyzed oxidative C-H alkenylation for synthesizing arylvinyltriazole nucleosides. Org. Biomol. Chem. 2015, 13, 110-114. [CrossRef] [PubMed]

138. Liu, W.; Li, Y.; Xu, B.; Kuang, C. Palladium-catalyzed olefination and arylation of 2-substituted 1,2,3-triazole N-oxides. Org. Lett. 2013, 15, 2342-2345. [CrossRef] [PubMed]

139. Trost, B.M. Atom economy-a challenge for organic synthesis: Homogeneous catalysis leads the way. Angew. Chem. Int. Ed. Engl. 1995, 34, 259-281. [CrossRef] 